\title{
Archaeological Survey and Archival Research of the Naegelin Tract (41BX1600) in San Antonio, Bexar County, Texas
}

Jennifer L. Thompson

Antonia L. Figueroa

Center for Archeological Research, University of Texas at San Antonio

Follow this and additional works at: https://scholarworks.sfasu.edu/ita

Part of the American Material Culture Commons, Archaeological Anthropology Commons, Environmental Studies Commons, Other American Studies Commons, Other Arts and Humanities Commons, Other History of Art, Architecture, and Archaeology Commons, and the United States History Commons

Tell us how this article helped you.

This Article is brought to you for free and open access by the Center for Regional Heritage Research at SFA ScholarWorks. It has been accepted for inclusion in Index of Texas Archaeology: Open Access Gray Literature from the Lone Star State by an authorized editor of SFA ScholarWorks. For more information, please contact cdsscholarworks@sfasu.edu. 


\section{Archaeological Survey and Archival Research of the Naegelin Tract (41BX1600) in San Antonio, Bexar County, Texas \\ Creative Commons License \\ (c) (1) (8)}

This work is licensed under a Creative Commons Attribution-NonCommercial 4.0 International License 


\section{Archaeological Survey and Archival
of the Naegelin Tract $(41 B \times 1600)$ in San Antonio, Bexar County, Texas}

\section{by \\ Jennifer $L$. Thompson and \\ Antonia L. Figueroa}

Center for Archaeological Research The University of Texas at San Antonio Archaeological Survey Report, No. 354 2005
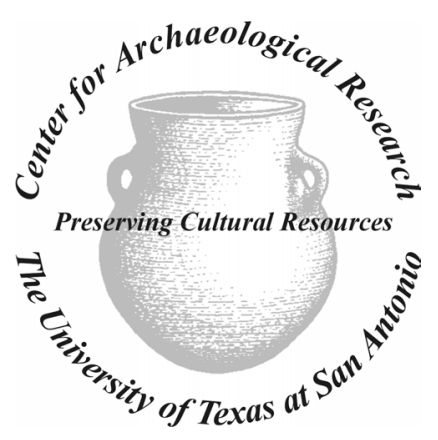


\title{
Archaeological Survey and Archival Research of the Naegelin Tract (41BX1600) in San Antonio, Bexar County, Texas
}

\author{
by \\ Jennifer L. Thompson and Antonia L. Figueroa
}

Texas Antiquities Permit No. 3597

Raymond P. Mauldin

Principal Investigator

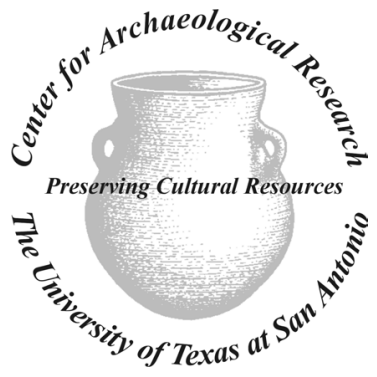

Center for Archaeological Research The University of Texas at San Antonio Archaeological Survey Report, No. 354 (C)2005 
A list of publications offered by the Center for Archaeological Research is available. Call (210) 458-4378; write to the Center for Archaeological Research, The University of Texas at San Antonio, 6900 N. Loop 1604 W., San Antonio, Texas 78249-0658; e-mail to car@utsa.edu; or visit CAR’s web site at http://car.utsa.edu. 


\section{Abstract:}

On December 2 and 3, 2004, the Center for Archaeological Research (CAR) conducted a Phase I survey of the 108acre Naegelin Tract in northwest Bexar County, Texas, for Raba-Kistner Consultants, Inc. The proposed development consists of extending De Zavala Road through the southern portion of the tract and Kyle Seale Road through the eastern margin of the tract. Drainage easements are planned to cross through the center of the property and also along the northern and eastern margins of the tract.

Thirty-six shovel tests were excavated along 30-meter transects and in areas considered to have high or moderate probability of buried cultural materials. No buried cultural materials were identified by any of the hand-excavated shovel tests. The survey resulted in the identification of eight isolated finds including one heavily fragmented projectile point that may represent a Bulverde dart point. This was the only artifact collected during the survey. No prehistoric sites were identified within the project area.

One historic site was identified during the survey (41BX1600). The survey documented the remains of a main stone building and nine outbuildings on the property. Although an age could not be determined based on the sparse artifacts noted on surface, the site appeared to represent a historic homestead built during the late nineteenth or early twentieth centuries. A 1939 aerial photograph of the area shows that many of the outbuildings and the main stone structure had been built by this date. Comprehensive deed research and oral histories conducted between February and June, 2005, helped to establish that the earliest structures on the complex were built in 1888. This research also revealed the presence of an unmarked grave on the property.

Subsequent to the pedestrian survey and prior to the completion of the archival research, the main stone building was severely damaged by fire. The fire damage exposed construction and architectural details not visible during the pedestrian survey. During a subsequent site visit, a tenth wood-framed outbuilding was identified. One isolated stone building of the same construction technique and age remained in good condition following the fire until it was recently torn down during asbestos abatement activities.

The principal stone-built structures on the compound were exceptional examples of Texas vernacular architecture of the late nineteenth and early twentieth centuries. The interior of the main stone structure had been dilapidated through years of neglect and abandonment, nonetheless, it retained structural integrity and exemplified changes in architectural elements over a period of roughly 10 years of additions to the original core structure. Following the fire, and the razing of the only undamaged building on site, the stone buildings retain no structural integrity and the site is not recommended as eligible for nomination to the National Register of Historic Places or for designation as a State Archeological Landmark. No additional archaeological work is recommended in association with this development.

These archaeological investigations were conducted under Texas Antiquities Committee permit number 3597 with Dr. Raymond P. Mauldin, CAR Assistant Director, serving as Principal Investigator. The single prehistoric artifact collected during the survey and a small number of potentially temporally diagnostic artifacts collected from the surface of 41BX1600 following the fire, as well as all project-related documents are curated at the Center for Archaeological Research at The University of Texas at San Antonio. 


\section{Table of Contents:}

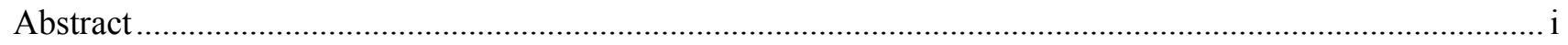

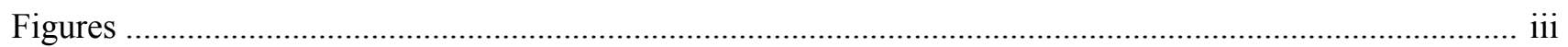

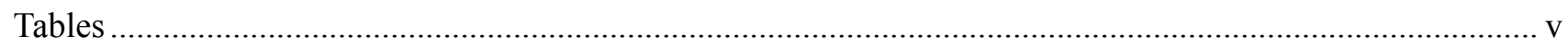

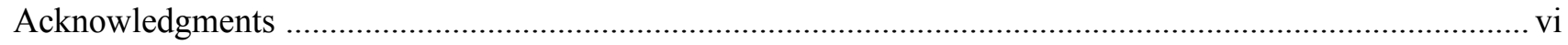

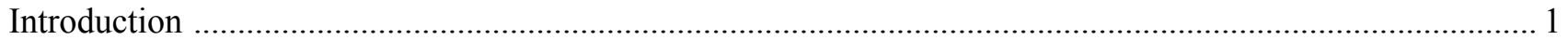

The Project Area and Known Archaeological Properties in the Vicinity ...................................................... 3

Archaeological Field and Laboratory Methods and Archival Research ...................................................... 3

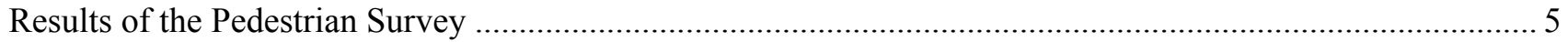

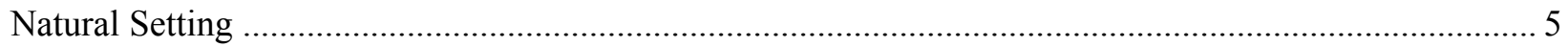

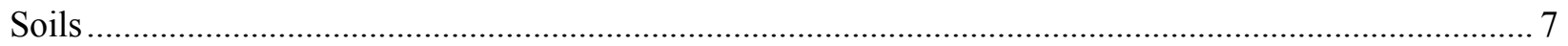

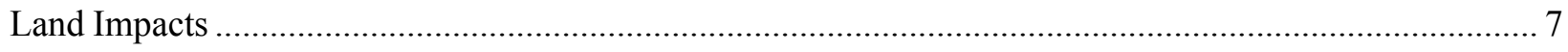

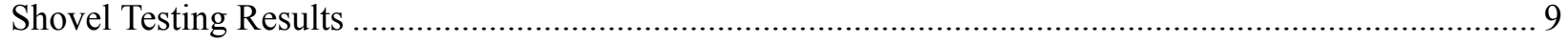

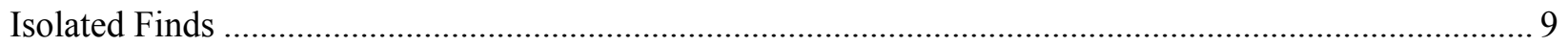

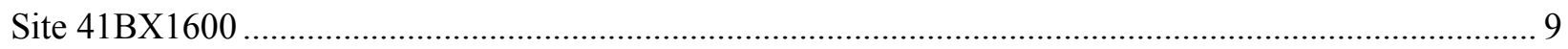

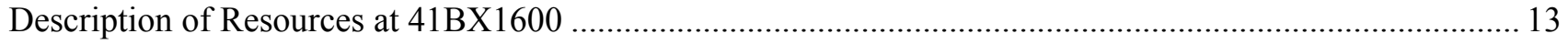

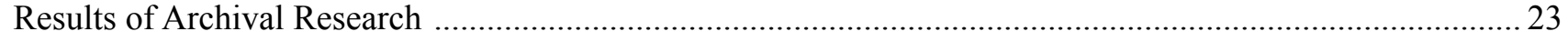

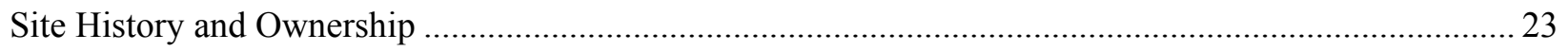

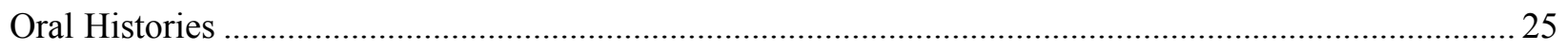

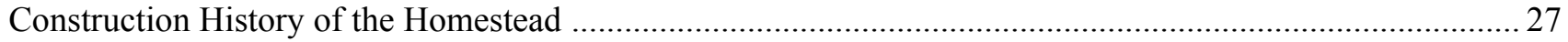

German Architectural Influence in San Antonio and Bexar County ...................................................... 33

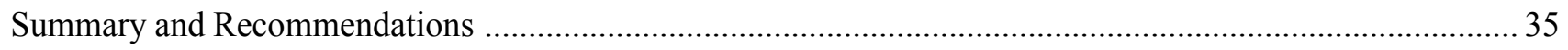

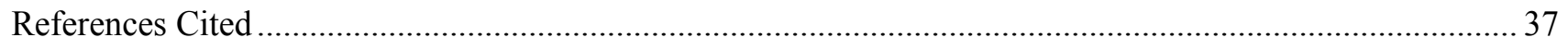

Appendix A: Genealogy of the Benke (Benko) Family ............................................................................. 40

Appendix B: Structural Integrity Inspection of 12930 South Hausman Road [Site 41BX1600] .................... 44

Appendix C: City of San Antonio Historic Design Review Commission Certificate of Appropriateness ....... 56 


\section{Figures:}

Figure 1. Location of the project area on the 1993 Helotes, Texas, USGS quadrangle. ......................................... 1

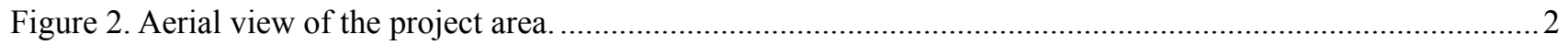

Figure 3. Planned construction impacts associated with development of the Naegelin Tract.................................. 4

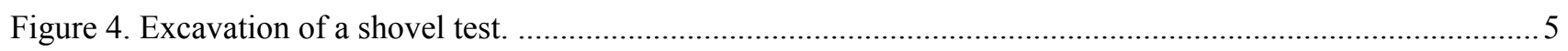

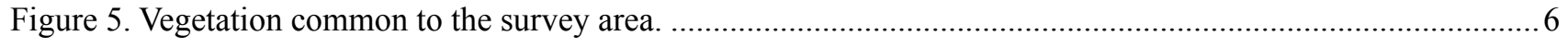

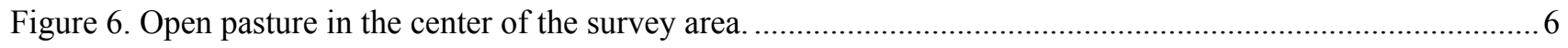

Figure 7. Cedars in the southern portion of the survey area. ..........................................................................

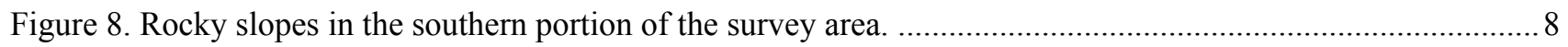

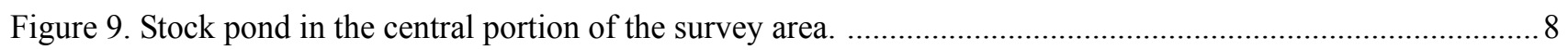

Figure 10. Field road and fence line in southwestern portion of the survey area. ................................................. 9

Figure 11. Locations of shovel tests, isolated finds, and site 41BX1600 ....................................................... 10

Figure 12. Isolated Find 3, a Bulverde-like Middle Archaic projectile point fragment. ....................................... 11

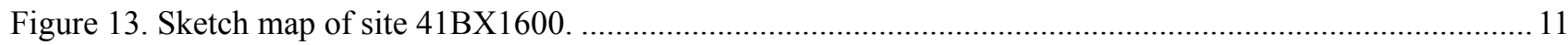

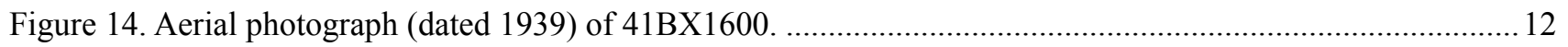

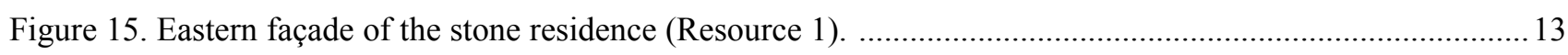

Figure 16. Detail of room division and condition of flooring (Resource 1) ..................................................... 14

Figure 17. Northern façade of residence (Resource 1) .................................................................................. 14

Figure 18. Porch floor and house foundation (Resource 1)......................................................................... 15

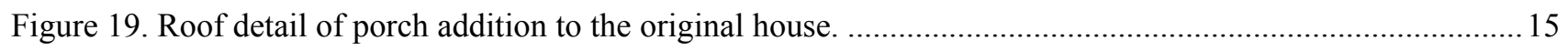

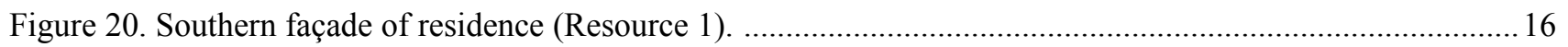

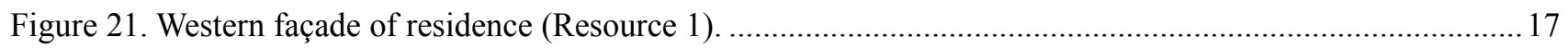

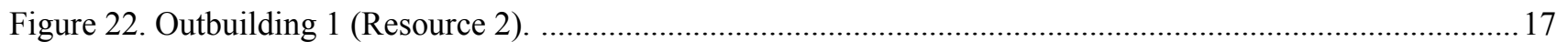

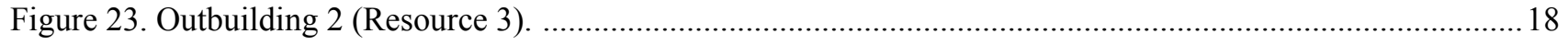

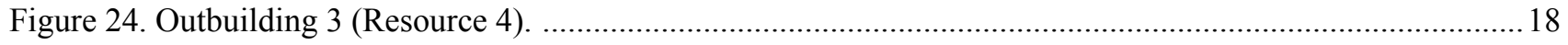

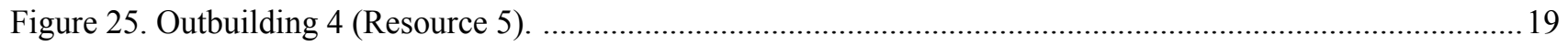

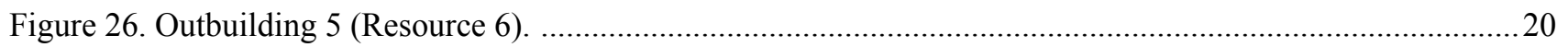




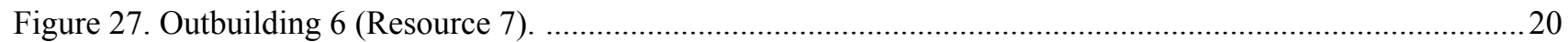

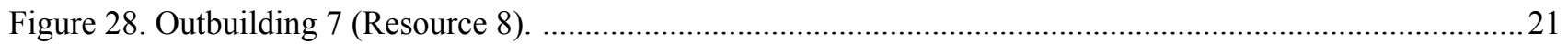

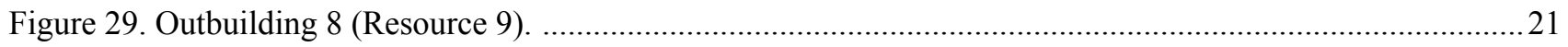

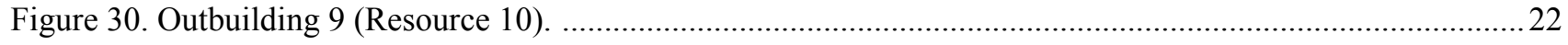

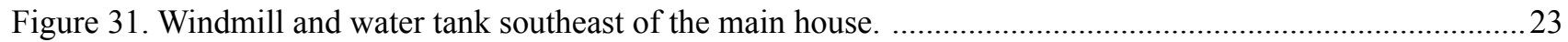

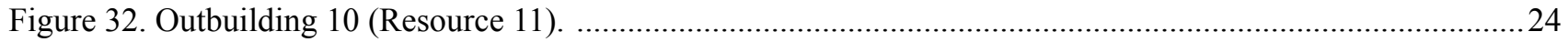

Figure 33. The 1927 Helotes, Texas, USGS quadrangle map showing the location of the 190.12 acres deeded to Dorothea Naegelin in 1936. Note A. Benke is shown as owner of the property...............................25

Figure 34. Wedding portrait of Alex J. Benke and Elisa Biering Benke (no date). ...............................................26

Figure 35. Alexander Benke (Benko) and Anna Elise Schmidt, parents of Alex J. Benke (no date). ......................26

Figure 36. Root cellar and smokehouse (Outbuilding 6) on the Benke/Naegelin property,

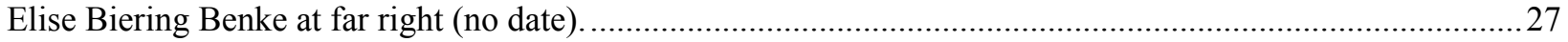

Figure 37. Front porch of the Benke/Naegelin homestead (no date). ................................................................2

Figure 38. Northeastern portion of Benke/Naegelin homestead property (barn in background; James Benke, left; Dorothy Naegelin, right; no date). .............................................................................28

Figure 39. Sketch floor plan of the stone portion of the Benke/Naegelin homestead. ............................................29

Figure 40. Abutment line and concrete floor of Addition 1 of Benke/Naegelin homestead. .................................. 30

Figure 41. Inside of original portion of homestead employing keystone above the window and doorway. .............30

Figure 42. Forged nail that originally supported wood framing around the south window of Addition 1 ................31

Figure 43. Abutment line and easternmost doorway of Addition 3 to Benke/Naegelin homestead. ........................31

Figure 44. Hearth in north wall of Addition 3. Also note north wall window and stonework detail. ......................32

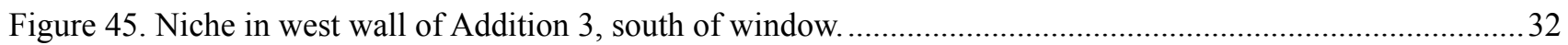

Figure 46. Chimney pipe above door to Addition 3. Note keystones above door in Addition 2 and window

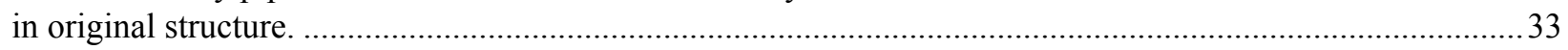

Figure 47. Wire nails that originally supported wood framing around the west doorway of Addition 2................34

Figure 48. Addition 3 of homestead with no keystones present and chisel marks on the limestone block...............34

Figure 49. Location of site 41BX1600 within the planned road construction right-of-way...................................35

Figure 50. Photograph of the Naegelin property after the razing of the main house and root cellar........................36 


\section{Tables:}

Table 1. Isolated Finds Recorded During Survey ..... 


\section{Acknowledgments:}

Although this project represented a two-day survey of a property located only a few miles from The University of Texas at San Antonio campus, several people have been very helpful with the logistical preparations, the actual survey, the archival research and oral history, the production of the draft report, review, and the final publication. The authors would like to thank Mr. Steve Jones of Raba-Kistner Consultants, Inc. for facilitating contractual aspects of the project and providing comments on the draft report. Mr. Bill Peters, the Scheduler-Compliance Coordinator with the Northside Independent School District, patiently accommodated the delays imposed by the rainy weather and was helpful in orienting the staff and providing access to the survey property. We would also like to express our sincere thanks to Ms. Mildred Babcock and Mr. Leroy Kneupper for providing invaluable information regarding their family's history, and for Ms. Babcock sharing her memories of the wonderful times she spent growing up on the Naegelin property.

The primary author would also like to thank Dr. Raymond P. Mauldin, the Principal Investigator, for accompanying her during the initial field visit and for subsequent advice during the preparation of the report. Thanks are also due to Dr. Steve A. Tomka, CAR Director, for his advice in preparing for the oral history research and in-house reviews of the draft and final report. Clearly, thanks are also due to the field crew composed of Brian Davis-Brothers, Jon Dowling, Antonia Figueroa, and Steve Smith for their hard work. Finally, thanks are also extended to Bruce Moses and Richard Young for drafting the figures and tracking down the 1939 aerial photograph and to Johanna Hunziker for editing the final manuscript. 


\section{Introduction}

In November of 2004, Raba-Kistner Consultants, Inc. of San Antonio contracted with the Center for Archaeological Research (CAR) of The University of Texas at San Antonio to conduct a Phase I pedestrian survey of an approximately 108-acre property located in northwest Bexar County, Texas. The property is known as the Naegelin Tract and is owned by the Northside Independent School District. Figure 1 shows the project area on the 1993 edition of the Helotes, Texas, 7.5' USGS quadrangle map. An aerial view of the project area is shown in Figure 2.

As part of the contract deliverables, CAR conducted a 100 percent pedestrian survey of the project area during December of 2004. Subsequent to the survey and production of a draft survey report, and while the Texas Historical Commission (THC) was reviewing the draft report, Raba-Kistner Consultants requested the completion of archival background research on the property and accordingly amended the contract. The bulk of the archival background research and oral history work was carried out between February and March, 2005. In April, CAR submitted a second draft report that incorporated the comments of the THC reviewer and the results of the archival background and oral history research. The collection of oral history continued while the second draft was reviewed and this final report incorporates a small amount of additional information not contained in the second draft. This information did not change the eligibility assessment of the site as presented in the second draft. Finally, this final report also addresses the comments of the THC made regarding the second draft report.

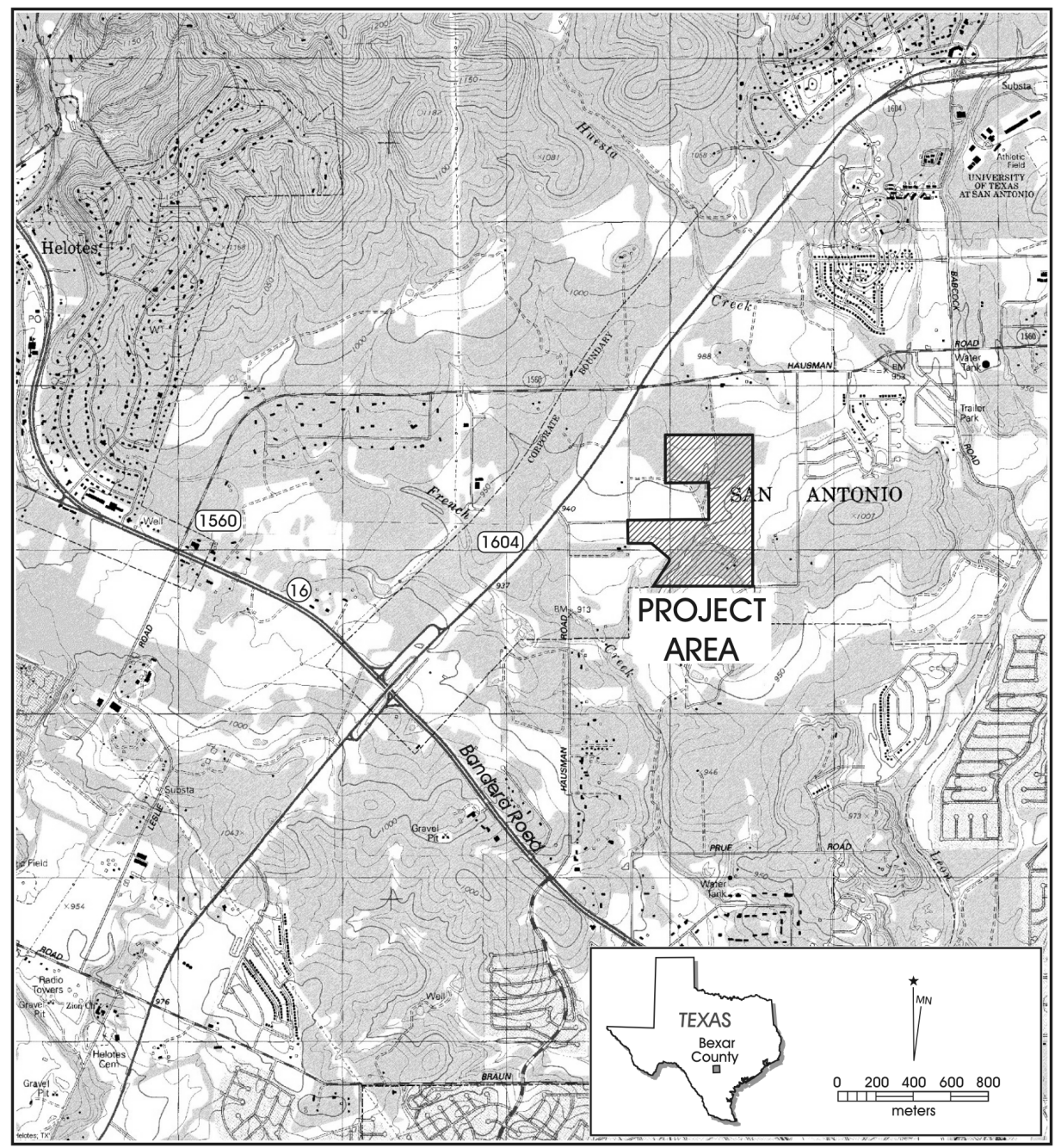

Figure 1. Location of the project area on the 1993 Helotes, Texas, USGS quadrangle. 


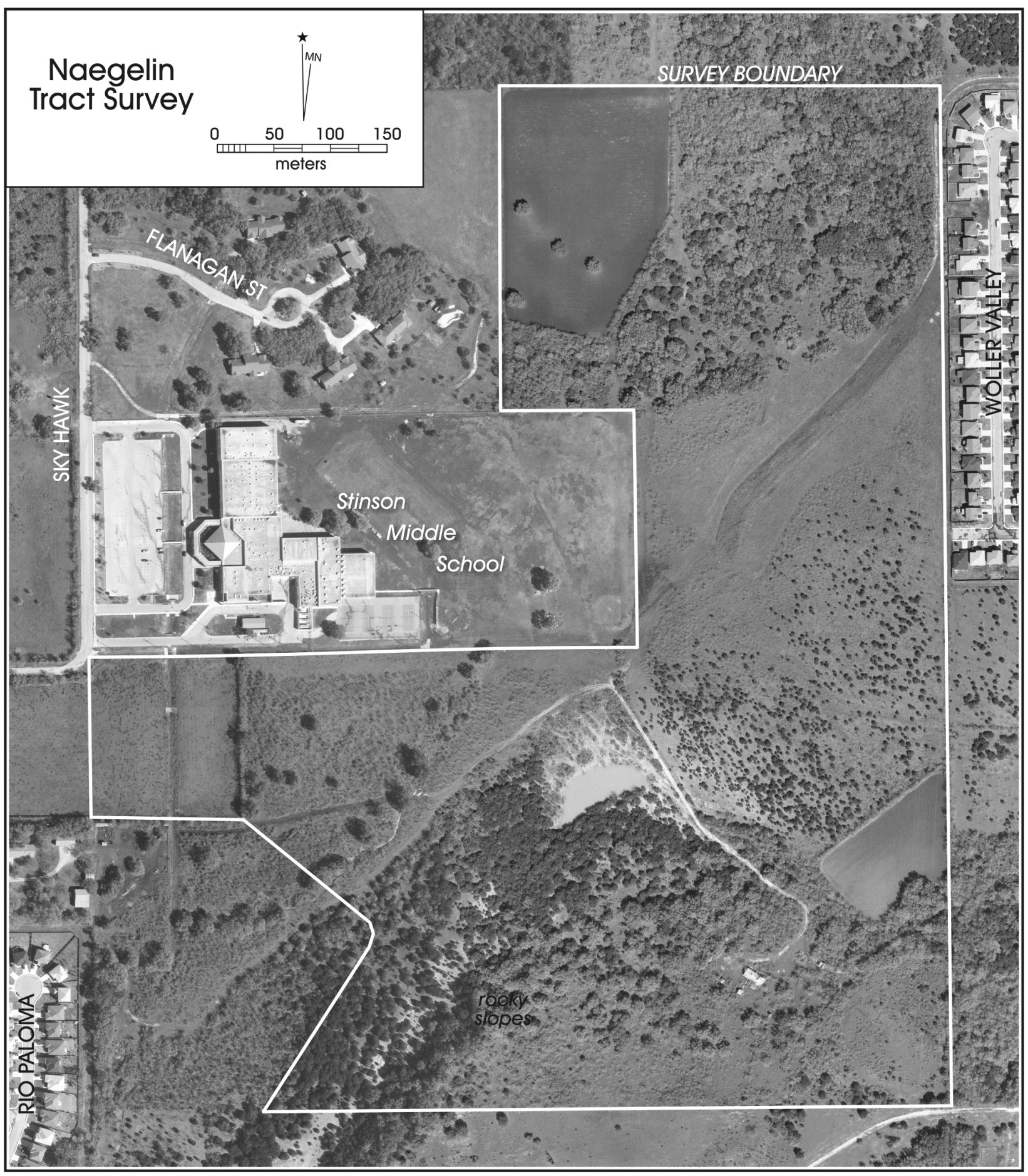

Figure 2. Aerial view of the project area. 
The Naegelin Tract is located immediately inside Loop 1604 northeast of State Highway 16. The property is bound on the west by Stinson Middle School and residential developments along Flanagan Street and Rio Paloma Street. Part of the eastern margin also abuts residential development (Woller Valley) but the northern and southern boundaries of the tract are formed by fence lines through undeveloped lands.

While the entire 108 acres is considered the Area of Potential Effect (APE) due to primary and secondary development impacts, the area of primary impact will concentrate along two planned road right-of-ways and a number of drainage easements (Figure 3). A significant component of the development project is the extension of two roadways-De Zavala Road through the southern portion of the tract and Kyle Seale Road through the eastern portion of the tract. Drainage easements are planned to cross through the center of the property and also along the northern and western margins of the tract.

These archaeological investigations were conducted under Texas Antiquities Committee permit number 3597 with Dr. Raymond P. Mauldin, CAR Assistant Director, serving as Principal Investigator.

\section{The Project Area and Known Archaeological Properties in the Vicinity}

Though the survey was conducted in an urban area, the landscape under study here remains undeveloped. The project area occupies land from 930-950 feet AMSL. The topography of the project area ranges from level to sloping terrain. An unnamed tributary of French Creek originates at the very south-central margin of the property and French Creek proper and other tributaries flow within a mile to the west and south of the property. The northern portion of the APE contains open pastures with tall grasses and wooded patches of oak along with prickly pear, Spanish dagger, mesquite and agarita. The southern portion of the APE has greater topographic relief with very rocky soils and thick stands of cedar and oak. The entire project area is cross-cut with fences and field roads.

A review of the Texas Archeological Sites Atlas (THC 2004) indicates that there are no previously recorded prehistoric or historic archaeological sites within the Naegelin Tract project area. The nearest prehistoric site to the proposed project area is 41BX69, a possible Middle Archaic open campsite, located roughly $0.7 \mathrm{~km}$ due west of the southern corner of the project area in the right-of-way of Loop 1604. The nearest historic site, 41BX1591, is a dump site located about $0.5 \mathrm{~km}$ south of the project area and about $0.25 \mathrm{~km}$ north of French Creek. At the time of its recording, the dump contained a large quantity of mid- to late-nineteenth-century artifacts including ceramics, bottles, and tin cans. Modern debris was also present. The currently proposed development will not impact either of these previously recorded sites.

\section{Archaeological Field and Laboratory Methods and Archival Research}

To carry out the cultural resources inventory of the project area, CAR was to conduct a 100 percent pedestrian survey of the proposed project area accompanied by subsurface testing. Both archaeological and standing structural resources were to be considered using visual inspection of the surface and sub-surface shovel testing as determined appropriate by the project archaeologist. The initial estimates of the project area suggested that the tract measured 155 acres. Five acres consisted of heavily eroded patches and a livestock tank in the southern portion of the project area. Portions of these five acres were to be surface inspected but not shovel tested. On the remaining 150 acres, a total of 50 shovel tests was to be excavated as part of the original scope of work submitted with the permit application. Prior to the start of fieldwork, the client (Raba-Kistner) reduced the project boundary and the resulting tract was 108 acres.

As part of the pedestrian survey, archaeologists traversed the APE in 30-m transects while placing shovel tests evenly across the tract and/or in areas of high probability for recovering archaeological materials as judged appropriate by the project archaeologist. A total of 36 shovel tests was excavated to meet the rate of one (1) shovel test per three (3) acres dictated but the Minimum Survey Standards of the Texas Historical Commission. All shovel tests were manually excavated to $60 \mathrm{~cm}$ below ground surface $(\mathrm{cmbs})$ unless otherwise prohibited (Figure 4). Each test was excavated in $10-\mathrm{cm}$ levels and measured $30 \mathrm{~cm}$ in diameter. Matrix from each level was screened through $1 / 4$-inch mesh. Shovel test forms were completed for each test, noting observations about the soils, artifacts, and any other pertinent information relevant to the survey. All field forms were completed with pencil. All shovel test locations were recorded using a Trimble GeoExplorer II Global Positioning System (GPS) 


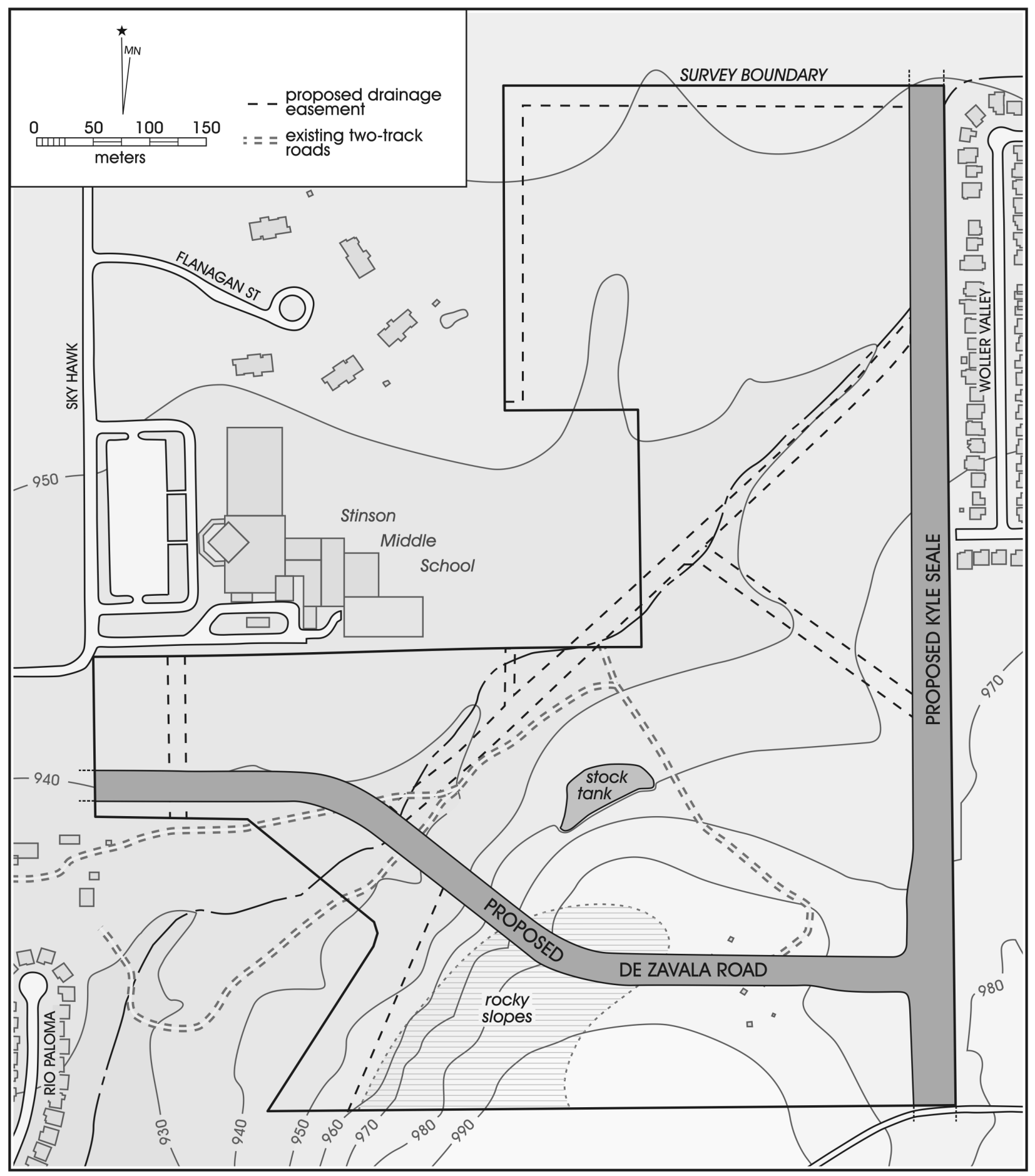

Figure 3. Planned construction impacts associated with development of the Naegelin Tract. 
unit and sketched onto aerial photographs and the topographic quadrangle map.

Isolated finds were defined as artifacts that do not constitute a site because these single specimens were found at a distance of 30 or more meters from other surface cultural materials. All isolated finds were mapped with a GPS unit. Only those artifacts exhibiting characteristics diagnostic of specific cultural groups or time periods were collected. All other surface artifacts observed in the field were described in the field notes and left in place.

Part of the archaeological survey included the documentation of any standing structures that were assessed to be 50 or more years old. A site form was completed for each newly recorded site and submitted to the Texas Archeological Research Laboratory for a permanent trinomial site number.

In case of artifact recovery, the specimens were to be washed, air-dried, and stored in 4-mil zip-locking bags at the CAR laboratory. Acid-free labels were to be placed in all artifact bags. Each label was to include provenience information and a corresponding lot number and written in archival ink, pencil or laser printer generated. Tools and ceramics were to be labeled with permanent ink over a clear coat of acrylic and covered by a second acrylic coat. In addition, a small sample of unmodified debitage from each lot was to be labeled with the appropriate provenience data. Artifacts were to be separated by class and stored in acid-free boxes identified with standard tags.

All project-related field notes, forms, photographs, and drawings were placed in labeled archival folders. Photographs, slides, and negatives were labeled with archivally appropriate materials and placed in archival-quality sleeves. Any soiled shovel test forms were placed in archival-quality page protectors. Ink-jet produced maps and illustrations also were placed in archival-quality page protectors to provide against accidental smearing due to moisture.

The archival investigations of the Naegelin property consisted of examining Bexar County deed records, cemetery records, obituaries and marriage certificates. Oral histories of the property were also compiled from interviews with family members who were connected to the property. In addition, aerial photographs and early maps of Bexar County (topographical and survey) were also used to investigate the ownership history of the homestead property.

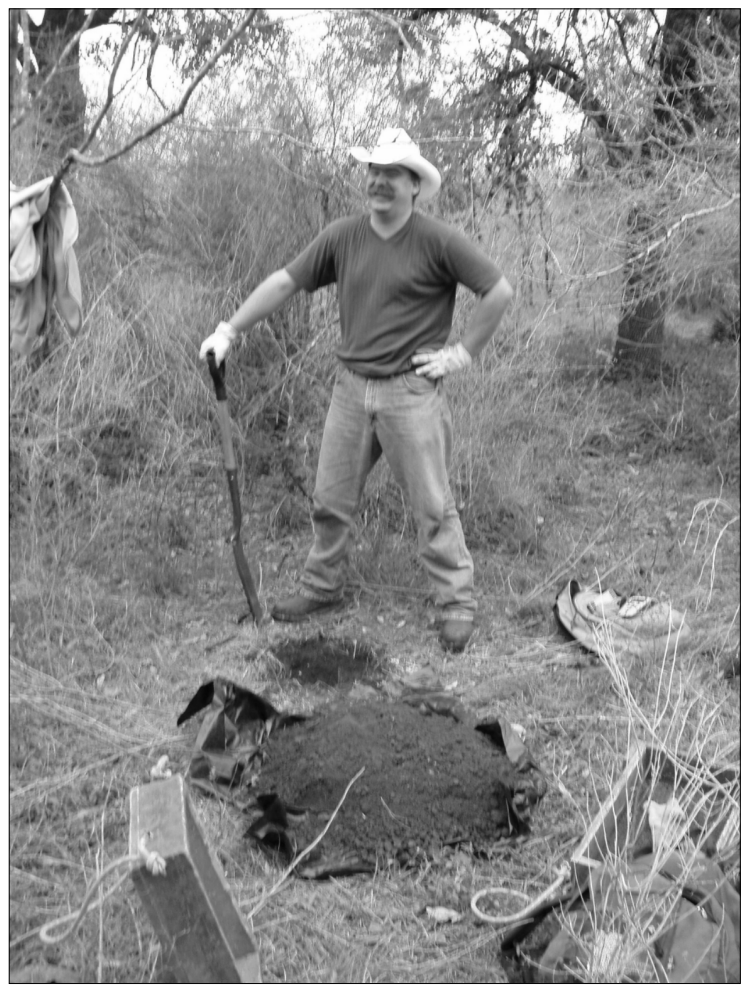

Figure 4. Excavation of a shovel test.

\section{Results of the Pedestrian Survey}

The survey began December 2, 2004, and concluded December 3, 2004, under the direction of Jennifer Thompson, CAR Project Archaeologist. The initiation of the survey was delayed several days from its original date given the heavy rains that fell during the weeks of November 21 and 28. A total of 36 shovel tests, primarily concentrated in the northern and central portions of the project area, was excavated during the survey.

\section{Natural Setting}

Survey transects crossed vegetation ranging from thick, nearly impassable cedar groves to open pastures of tall grasses. Prickly pear, mesquite, Spanish dagger, agarita, and oak trees were also present throughout all sections of the APE (Figure 5). Open pastures were present in the northern and central portions of the survey area (Figure 6) along with dense stands of oak in the northeast corner. In the southern portion of the survey area, cedars and oaks were present on 


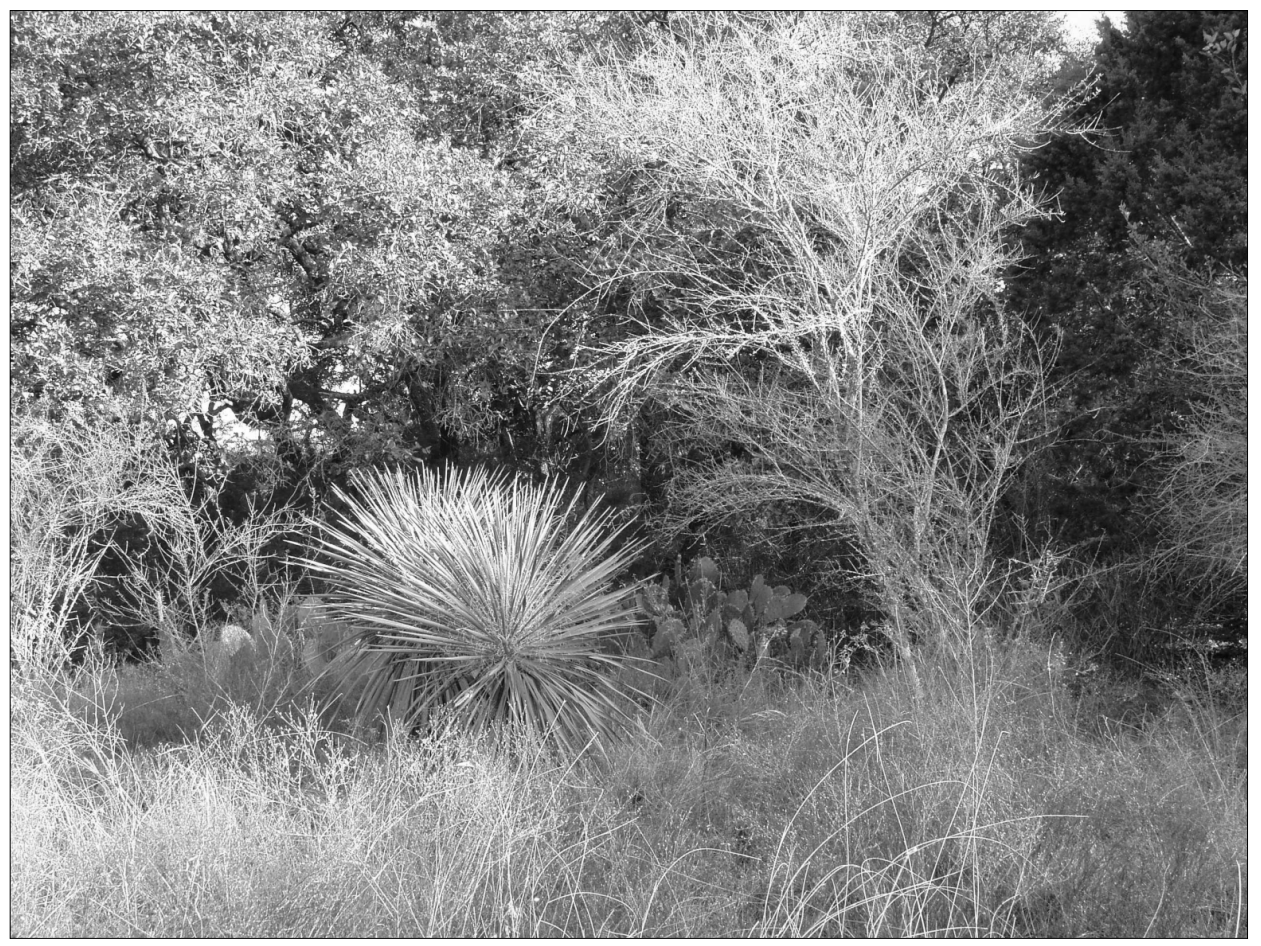

Figure 5. Vegetation common to the survey area.

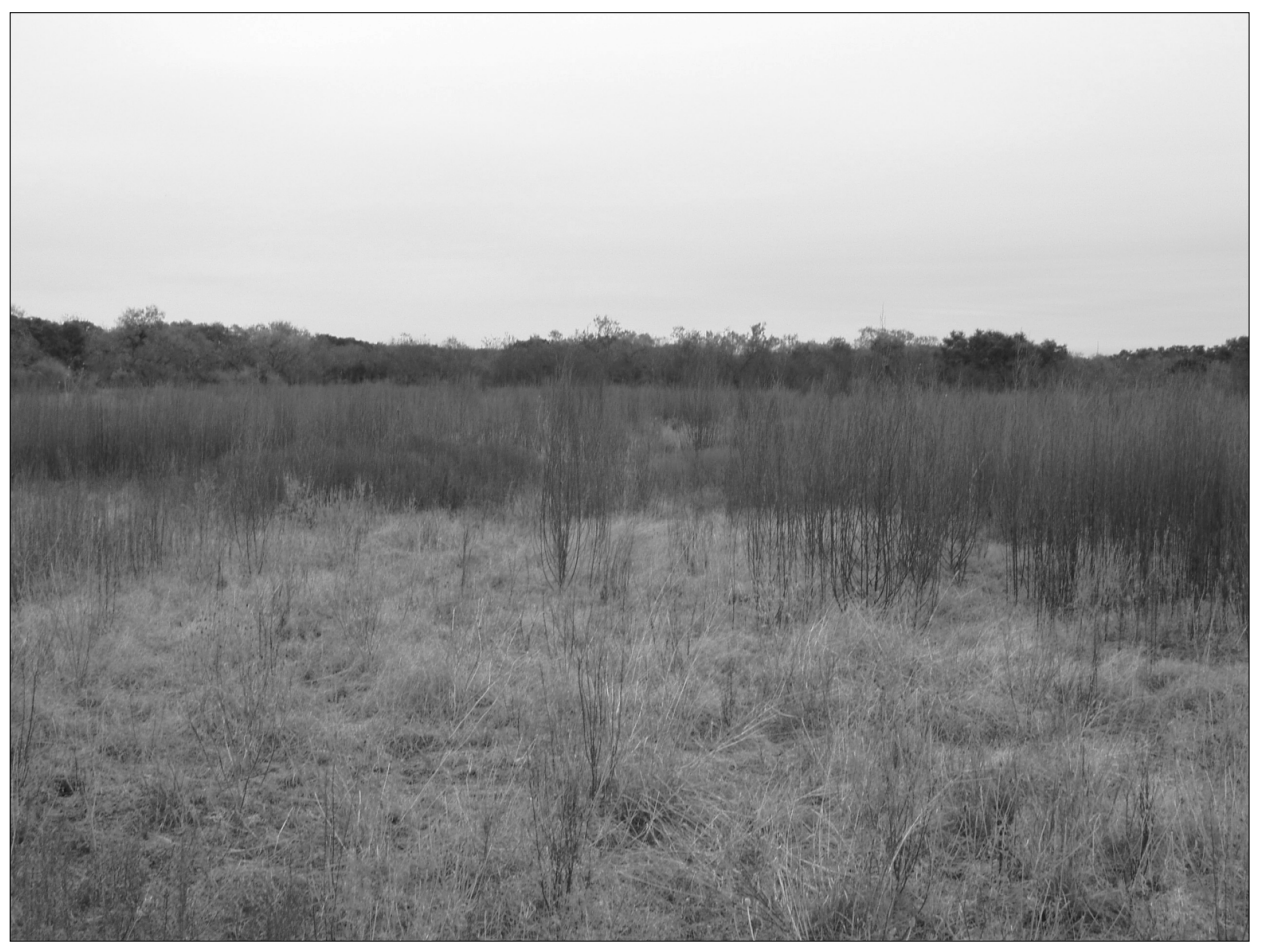

Figure 6. Open pasture in the center of the survey area. 
steep, rocky slopes (Figures 7 and 8). In places, vegetation was only passable with the aid of game trails and a machete. A stock pond in the middle of the APE is visible on the aerial photograph near one of the larger field roads (Figures 2 and 9). In areas near the southern boundary, bedrock was exposed through shallow soils.

\section{Soils}

Four soils series were mapped in the survey area and are described in terms of field observations and the descriptions in the Bexar County Soil Survey (Taylor et al. 1962). In the northern reaches of the project area, Crawford series soils (Crawford and Bexar stony soils) were encountered. Field observations indicate that these are dark reddish-brown clay soils over gravel underlain by bedrock. Shovel tests in the northwestern pasture through this soil were shallow and did not reach $60 \mathrm{cmbs}$. Crawford clay, which has a similar color and texture, was encountered in the central pasture east of the school and reached depths of $60 \mathrm{cmbs}$.

Moving south across the survey area, Houston Black series (Houston Black Clay terrace 0-1 percent) were encountered.
These are fine textured clays, dark gray in color. These were also present in the pasture. The southeastern corner of the APE is mapped with Tarrant Association soils (gently undulating to rolling). These occurred on moderate slopes with limestone boulders and exposed bedrock. These soils were dark in color with a clay texture. They often occur with Krum complex and Crawford and Bexar stony soils.

At the location of 41BX1600, the Krum complex was encountered. These soils also occur on the terraces in the survey area over exposed rock. Shovel testing in these soils was nearly impossible due to the density of trees and underbrush and the shallowness of the soil.

\section{Land Impacts}

In general, the project area is an 'island' of vegetation within an urban area. Modern impacts to the land include numerous fences and field roads that cross-cut the property (Figure 10). In the field east of Stinson Middle School, surface access to underground water or sewer lines was observed indicating that the area has seen some disturbance in the recent past.

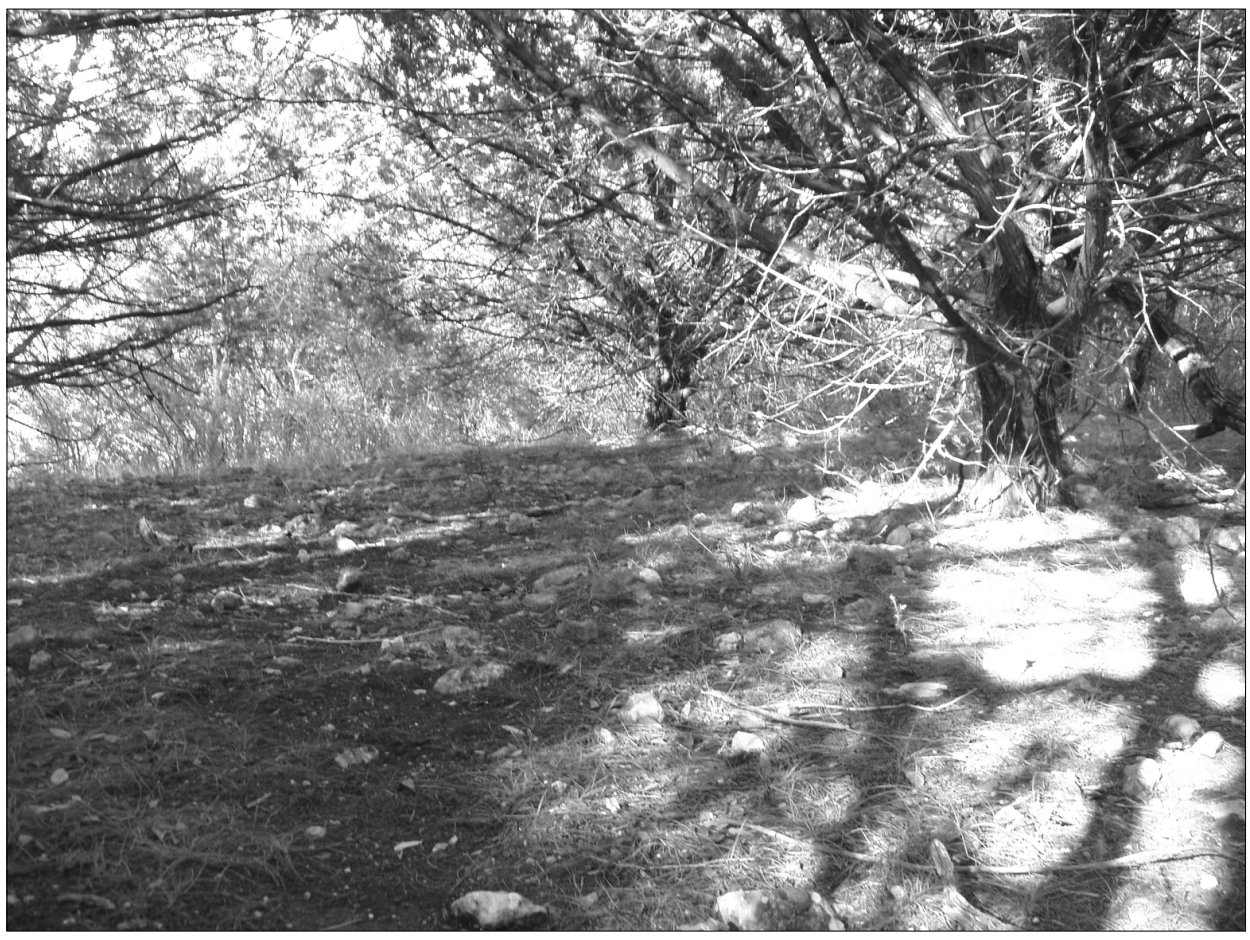

Figure 7. Cedars in the southern portion of the survey area. 


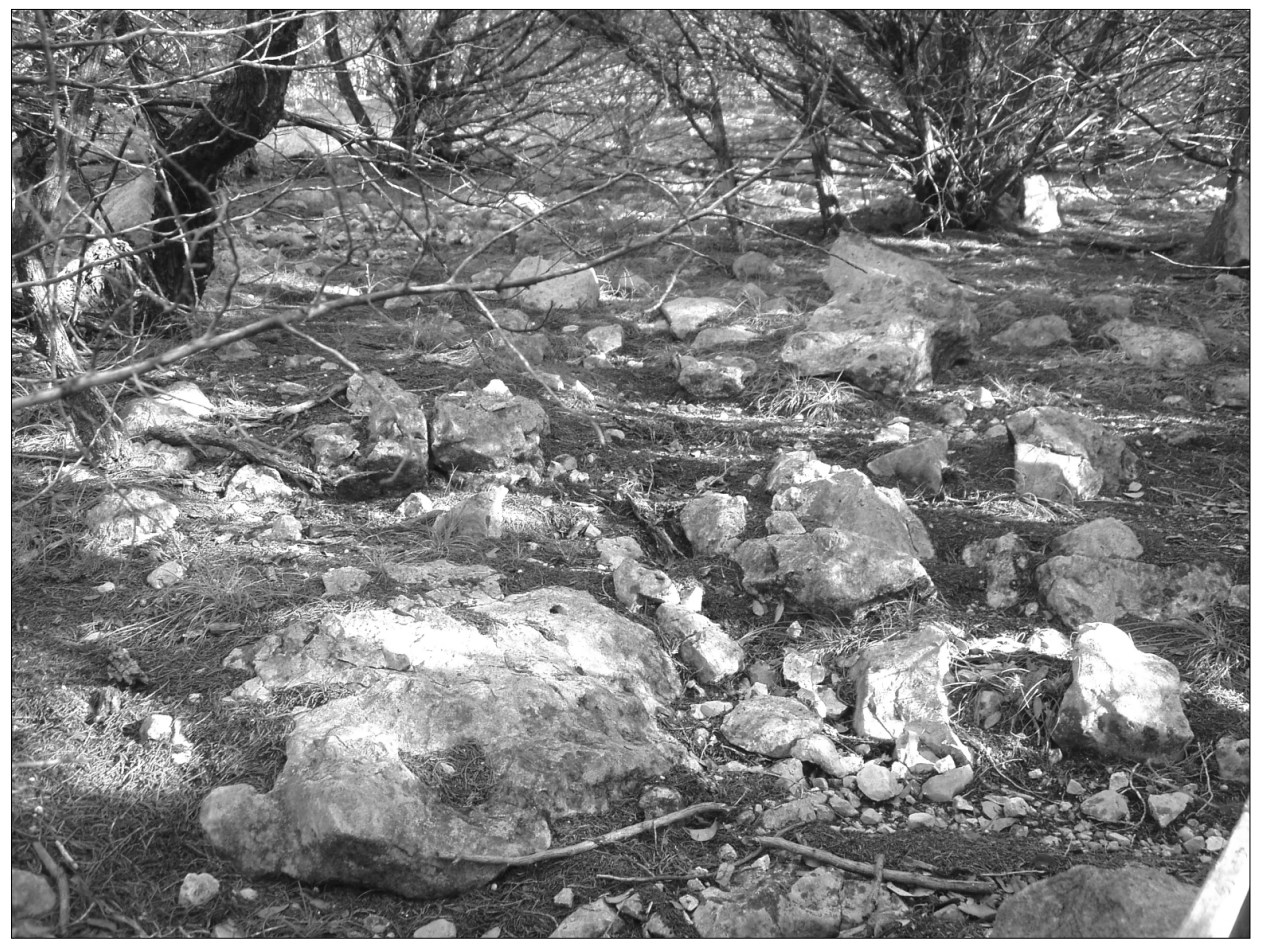

Figure 8. Rocky slopes in the southern portion of the survey area.

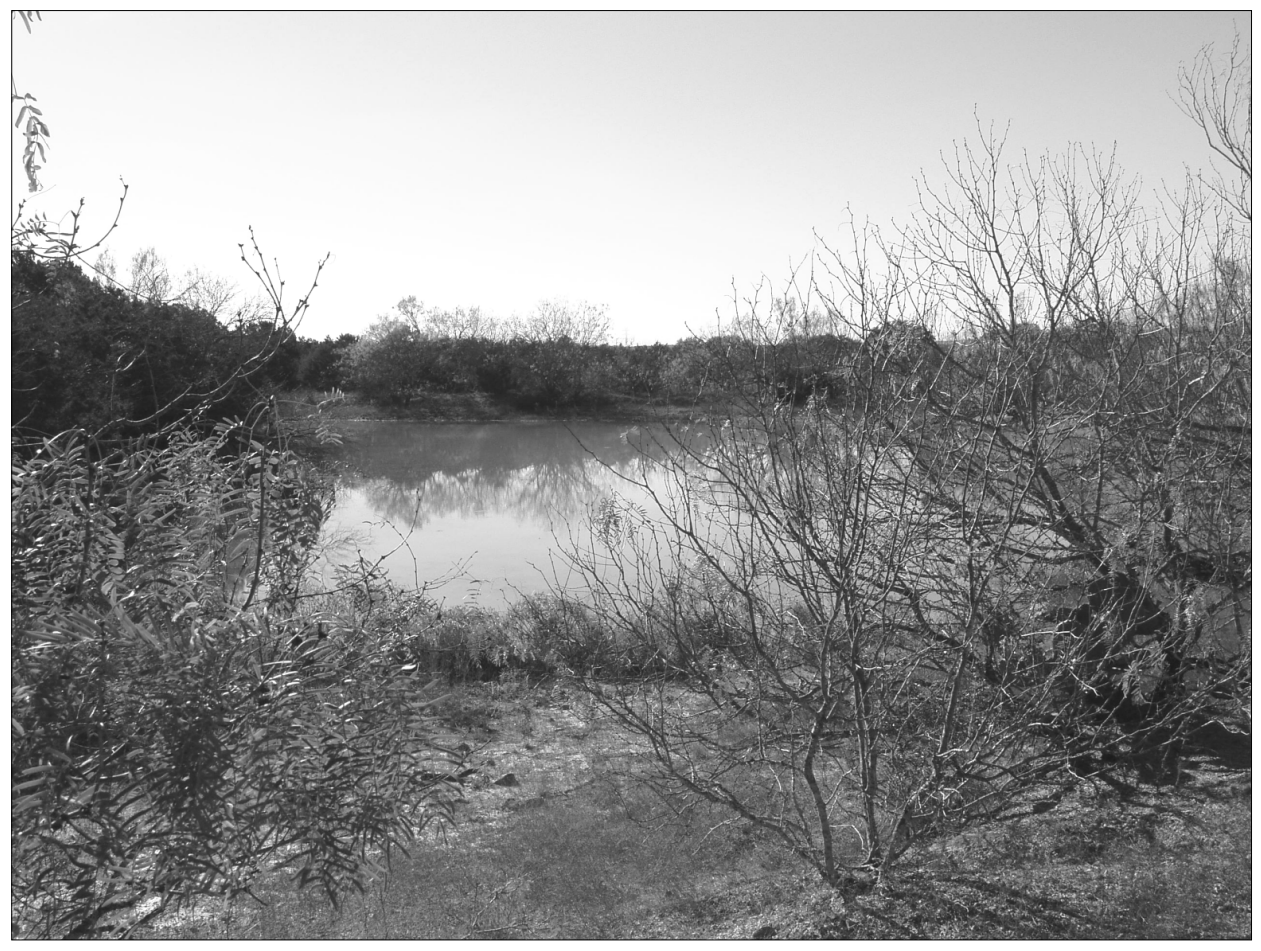

Figure 9. Stock pond in the central portion of the survey area. 


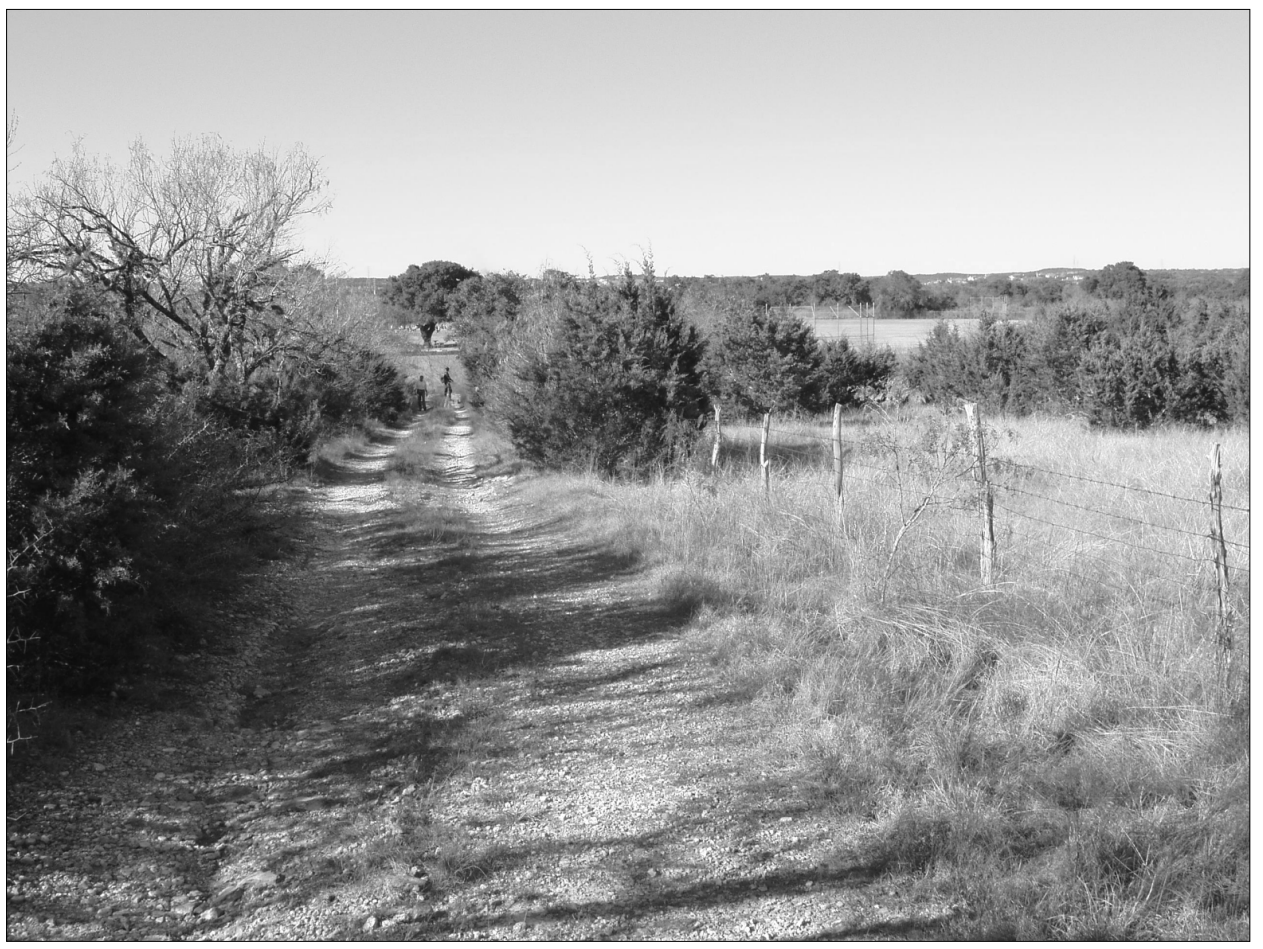

Figure 10. Field road and fence line in southwestern portion of the survey area.

\section{Shovel Testing Results}

Thirty-six shovel tests were excavated during the pedestrian survey (Figure 11). Thirty percent of the shovel tests could not reach $60 \mathrm{cmbs}$ due to impenetrable rock indicating that all four soil series noted during the survey across the APE were shallow or rocky in nature. No artifacts were found by the subsurface testing of the project area.

\section{Isolated Finds}

Eight isolated finds (IF) were recorded during the course of this survey (Table 1). All were identified on the surface in roadways or small drainages (Figure 11). Only one isolated find, IF3, was collected and returned to the lab. This is a heavily modified proximal fragment of a projectile point. Post-depositional impacts prevent its typing, although it appears Bulverde-like suggesting a Middle Archaic temporal affiliation (Figure 12).

The remaining seven isolated finds were not diagnostic of specific prehistoric culture groups or time periods and were not collected. They were all materials indicative of some stage of lithic reduction and are described in Table 1.

\section{Site 41BX1600}

One historic site was encountered during the course of this survey and falls within the proposed right-of-way of construction activities. The site consists of 11 structures, a concrete slab, a cattle chute, a windmill and a tank. Crew members photographed all the buildings, collected location data with GPS units, and created a sketch map of the area (Figure 13). Data collection included surface inspection of the entire site, sketches of all the buildings, numerous photographs, and collection of UTM coordinates for plotting on the topographic map. No artifacts were collected, though numerous artifacts such as whiteware ceramic sherds, scrap metal, and machinery parts litter the site. Several piles of scrap metal and wood sit at various points near the main house, which was still full of clothing, furniture and appliances at the time of the survey. A windmill and water tank stand southeast of the house. To the northeast is a concrete ramp used as a cattle chute.

The site appeared to be a historic farm complex. The original house structure resembled those constructed by German immigrants in central Texas during the mid-nineteenth century (Bracken and Redway 1956). 
This page has been

redacted because it

contains restricted

information. 
Table 1. Isolated Finds Recorded During Survey

\begin{tabular}{|c|l|}
\hline Isolated Find & Description \\
\hline 1 & Distal biface fragment \\
\hline 2 & Flake \\
\hline 3 & Proximal point fragment, Bulverde-like \\
\hline 4 & Flake \\
\hline 5 & Flake \\
\hline 6 & Flake \\
\hline 7 & Core \\
\hline 8 & Core \\
\hline
\end{tabular}

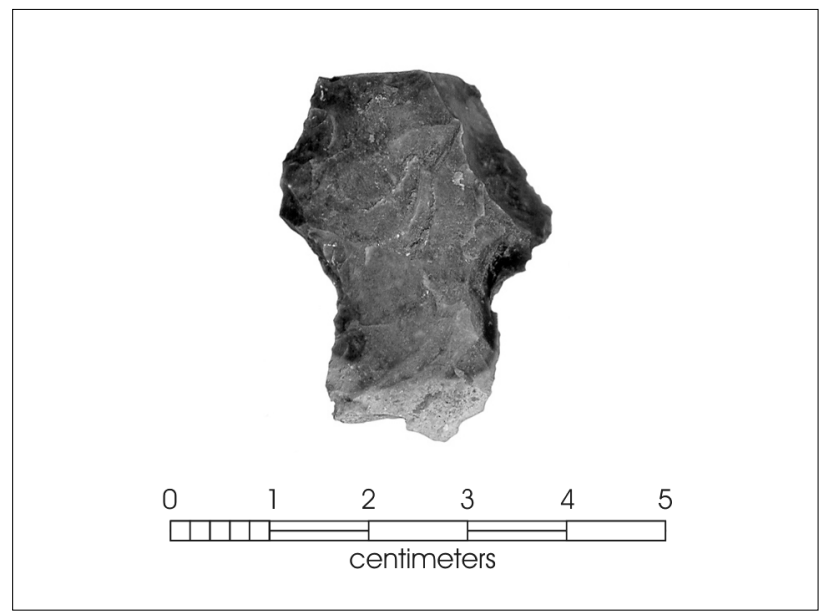

Figure 12. Isolated Find 3, a Bulverde-like Middle Archaic projectile point fragment.

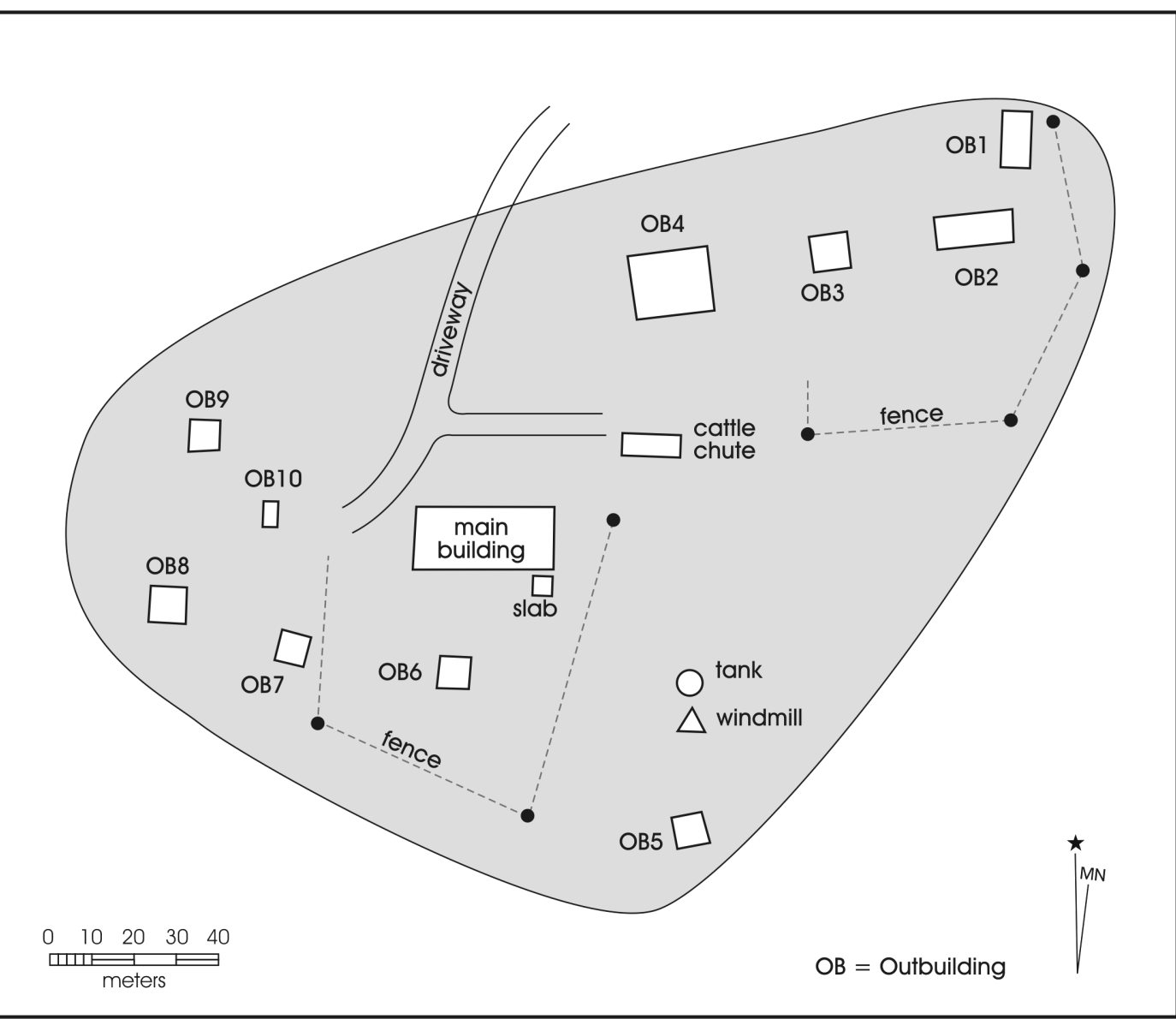

Figure 13. Sketch map of site $41 B X 1600$. 
A single shovel test (ST 34) was excavated on site at the time of the survey. The shovel test penetrated to a depth of $5 \mathrm{cmbs}$ before encountering bedrock. No artifacts were encountered. A further examination of the surface of the site indicated that bedrock was eroding across much of the hill where the site was located. Where bedrock was not observed immediately at surface, scraping of the surface with the tip of a shovel revealed eroding bedrock within $3-5 \mathrm{~cm}$. Therefore, it was decided that no additional shovel tests would be attempted within the site boundary. The limits of the site were defined based on the remnants of outbuildings rather than the more limited distribution of artifacts that were concentrated around the main residential stone structure. The outbuildings circumscribed an oval area measuring roughly $265 \mathrm{~m} \mathrm{x} 165 \mathrm{~m}\left(43,725 \mathrm{~m}^{2}\right)$.

The most useful resource available for establishing an approximate age for at least some of the structures on site was a 1939 aerial photograph (Figure 14) obtained from P2 Energy Solutions (formerly Tobin International) of San Antonio. This photograph shows a total of eleven buildings, a windmill and a tank present on the property. Of these eleven buildings, the CAR crew found no signs of three buildings (shown in blue) located in the northwest portion of the site. In addition, during the pedestrian survey the crew identified three buildings, a concrete slab and a cattle chute (shown in

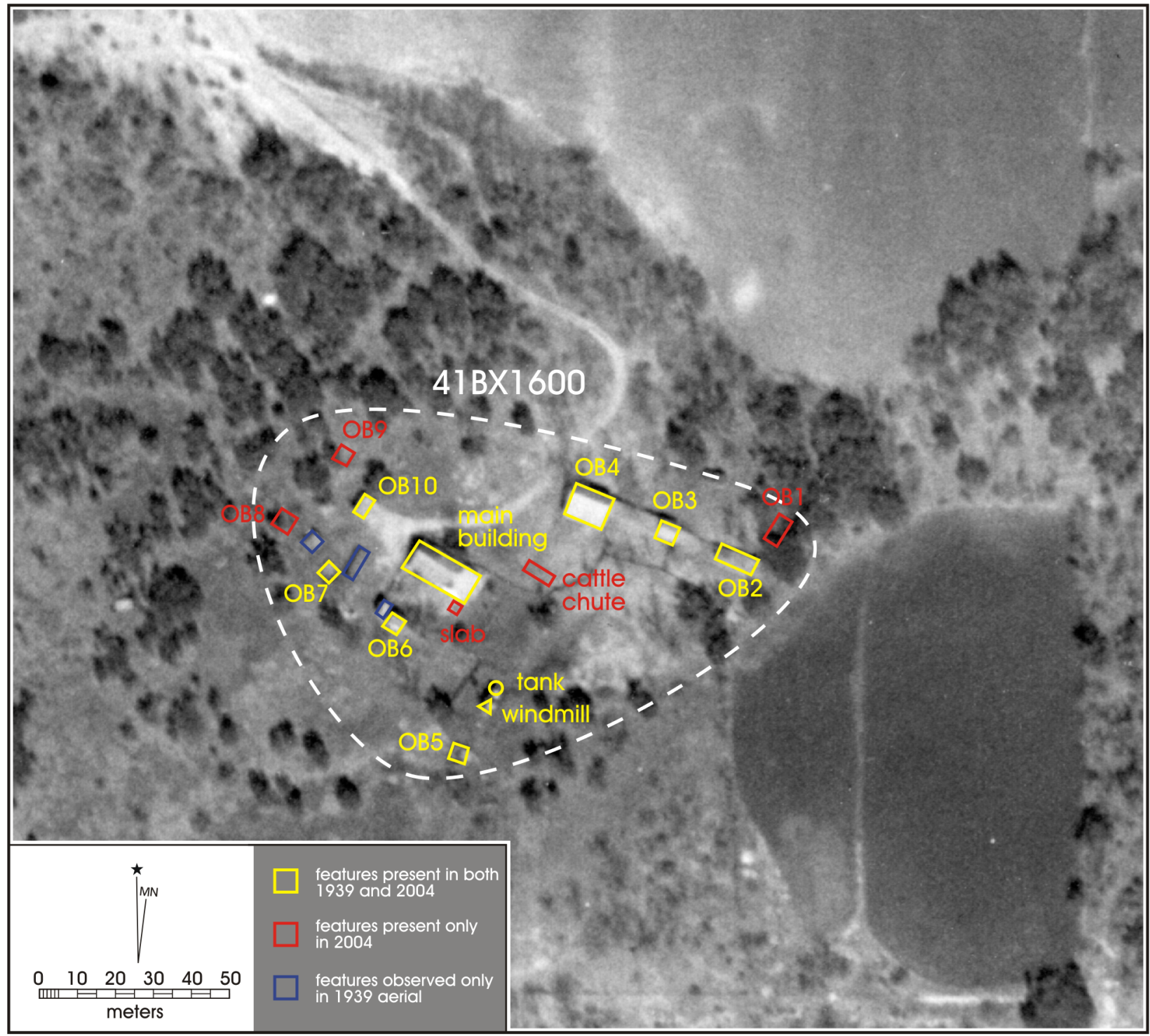

Figure 14. Aerial photograph (dated 1939) of 41BX1600. 
red) that do not appear on the 1939 aerial photograph indicating that they are later additions to the complex. The exact year or years when they were added is not known. The residence was inhabited until about 1982 (see Results of Archival Research section).

\section{Description of Resources at $41 \mathrm{BX} 1600$}

At the time of the CAR survey, a main residential building, nine outbuildings, a slab, a cattle chute, a tank, and a windmill were present on site. Based on a site visit (April 2005) with Mrs. Mildred Babcock, former resident of the homestead, it is clear that additional buildings were present on site but are no longer standing or visible. The following sections describe each of the resources identified by the CAR survey crew.

\section{Main Residence (Resource I)}

This is a single-story residence with a front-facing L plan of one-unit-wide cut-stone structures modified through two wooden additions. At the time of the survey, it was thought that the original house had been a single room, side-gabled stone cottage that was later split into two smaller rooms with a wall between the north window and the door (Figures 15 and 16). During the survey, the façade on the east elevation of the original structure included a central wooden door flanked by wood-framed, double-hung sash windows (Figure 15). The roof of the original structure was of standing seam metal.

Sometime after its initial construction, a rear L consisting of two stone structures was added to the original building (Figure 17). The larger, western-most structure was split into two rooms by an interior wall. Two doors with small stoops lead outside to the north and south in the middle structure and two windows provided a view to the outside to the north and west in the western-most structure that also has two south-facing doors. The floor of the rear $\mathrm{L}$ is poured concrete slab and the roof is covered with corrugated metal.

The first of the two wooden additions to the basic cut stone $\mathrm{L}$ plan was a porch added to the east elevation to shelter the front door and entrance. The porch had a concrete floor and was covered by an extended secondary roof of corrugated metal (Figures 18 and 19). No porch supports were present at the time of the survey; instead, tree limbs supported the roof.

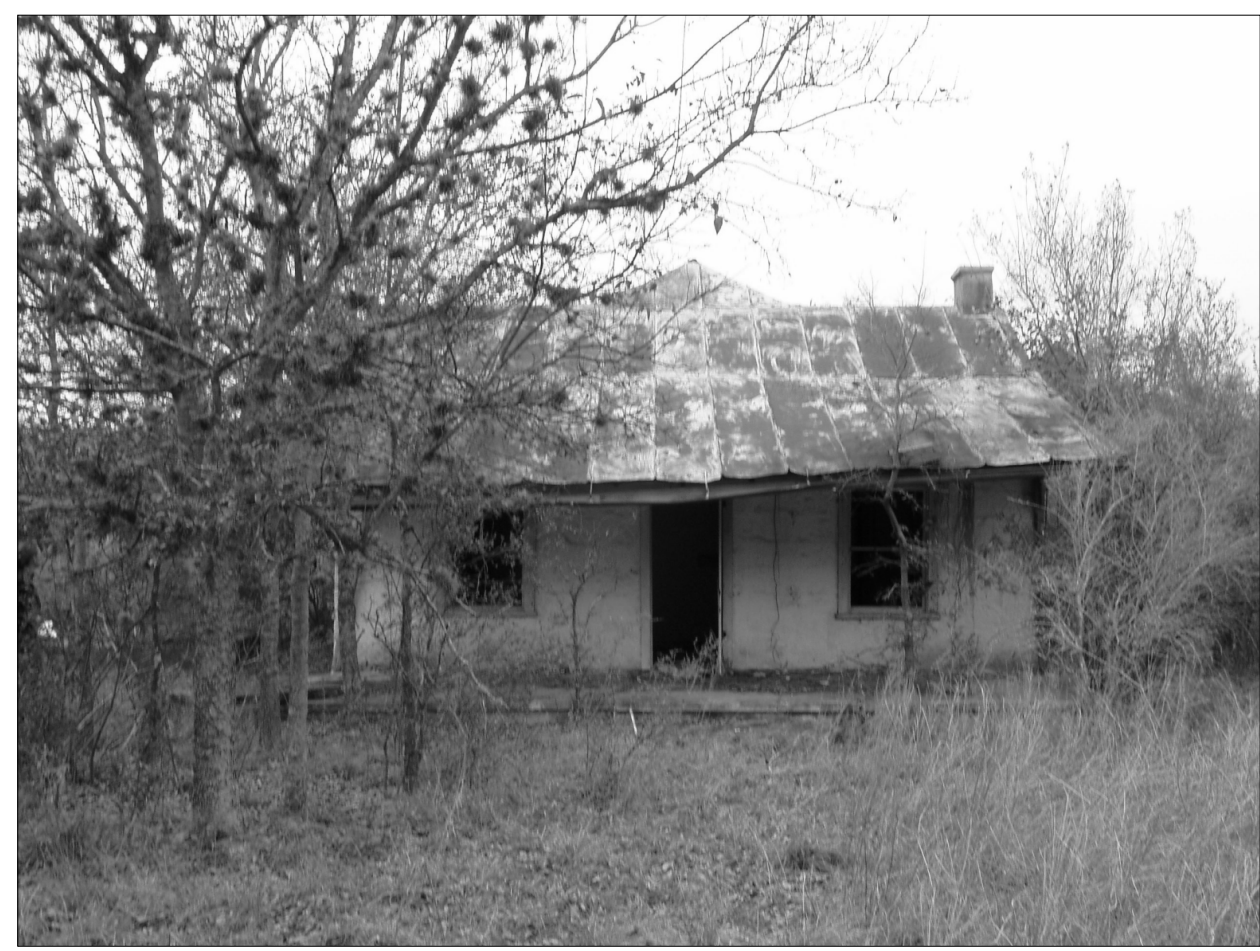

Figure 15. Eastern façade of the stone residence (Resource 1). 


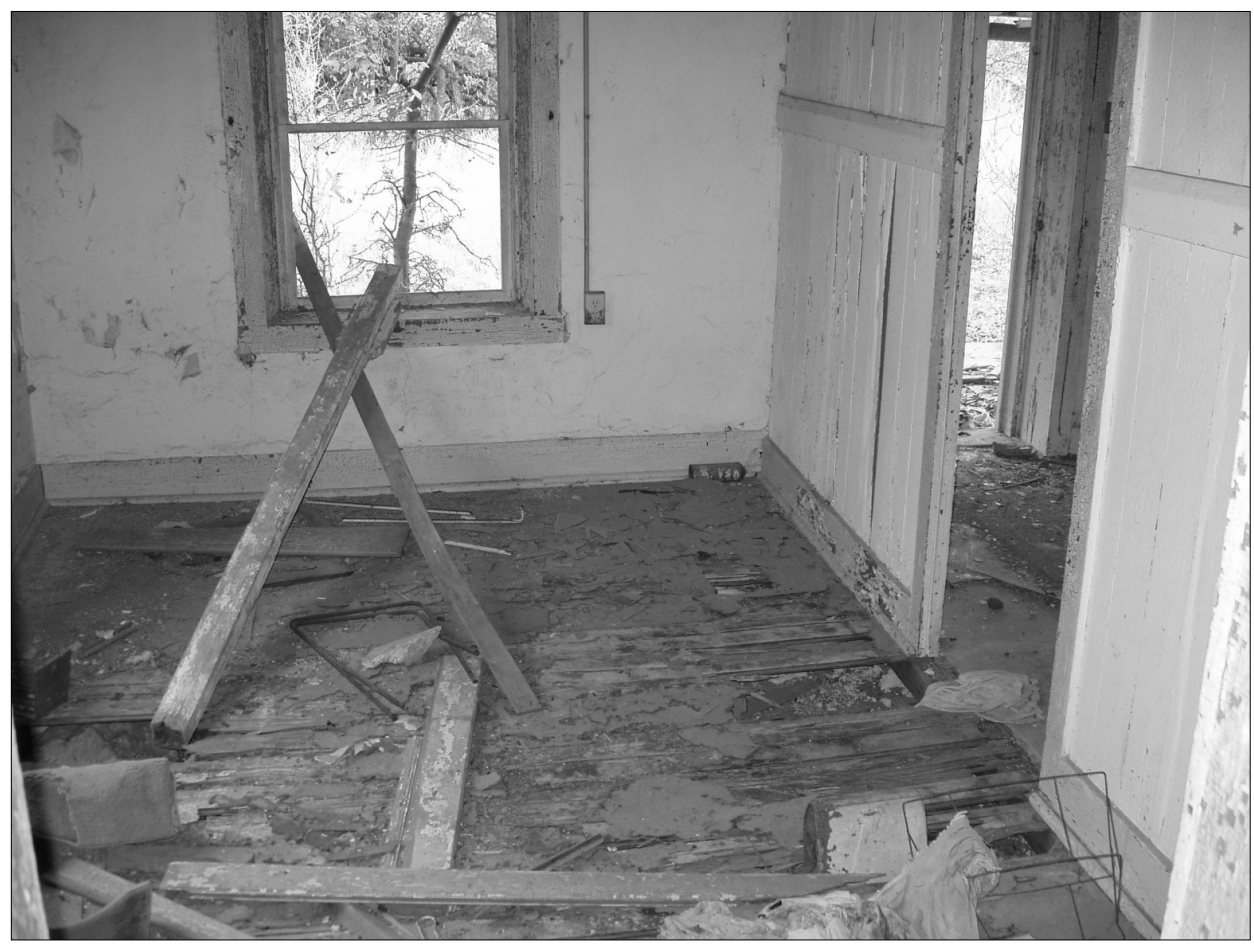

Figure 16. Detail of room division and condition of flooring (Resource 1).

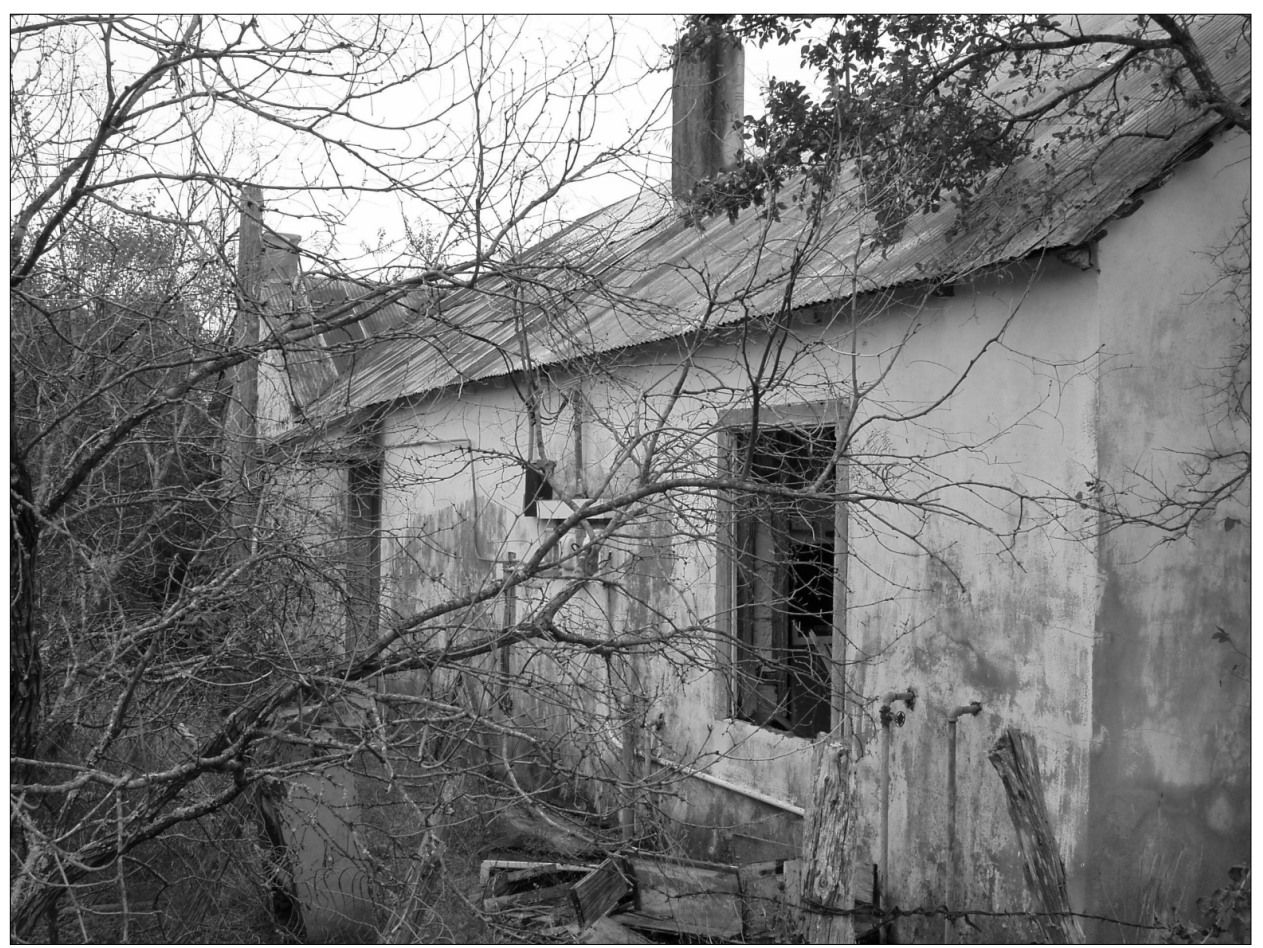

Figure 17. Northern façade of residence (Resource 1). 


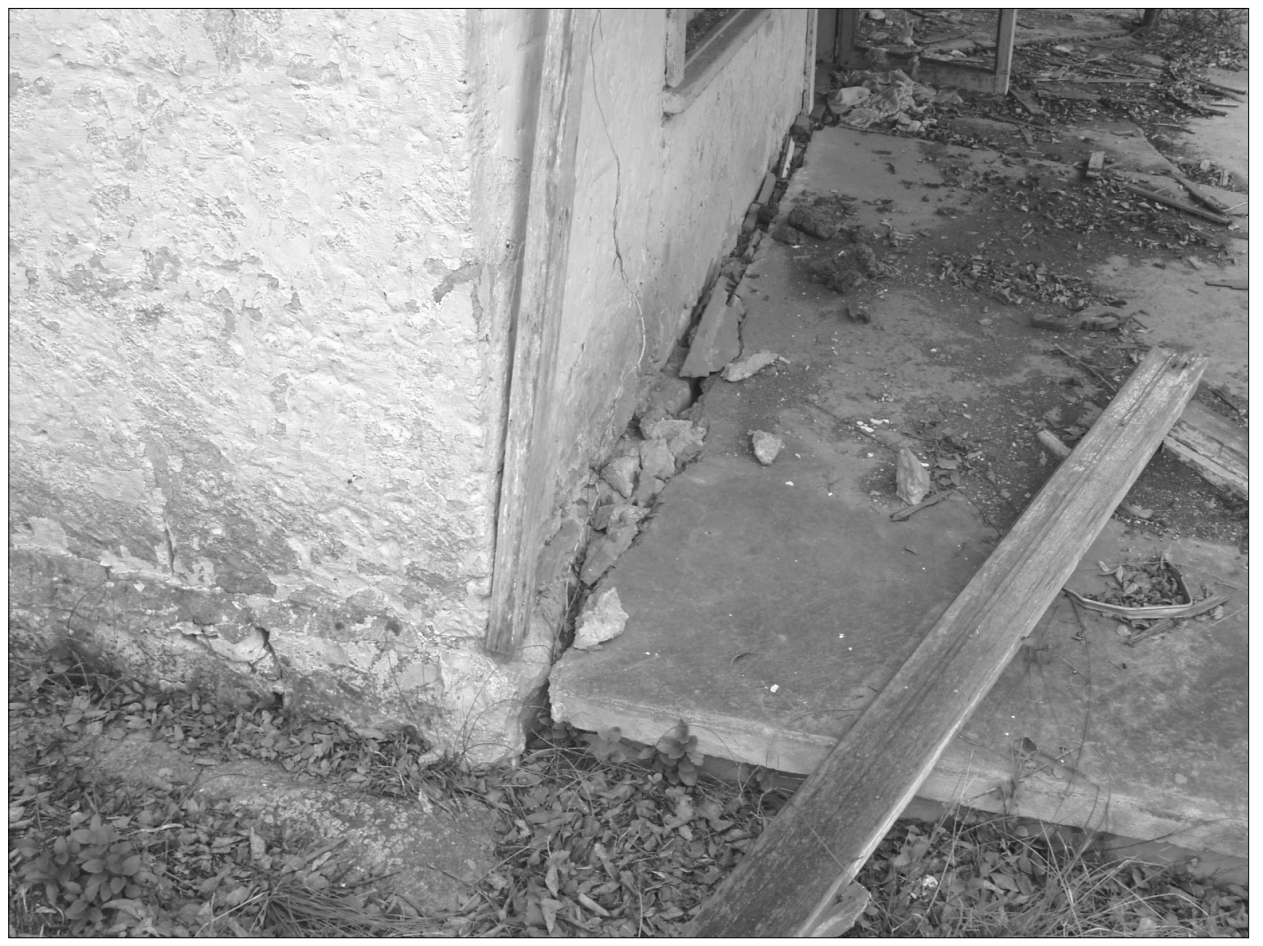

Figure 18. Porch floor and house foundation (Resource 1).

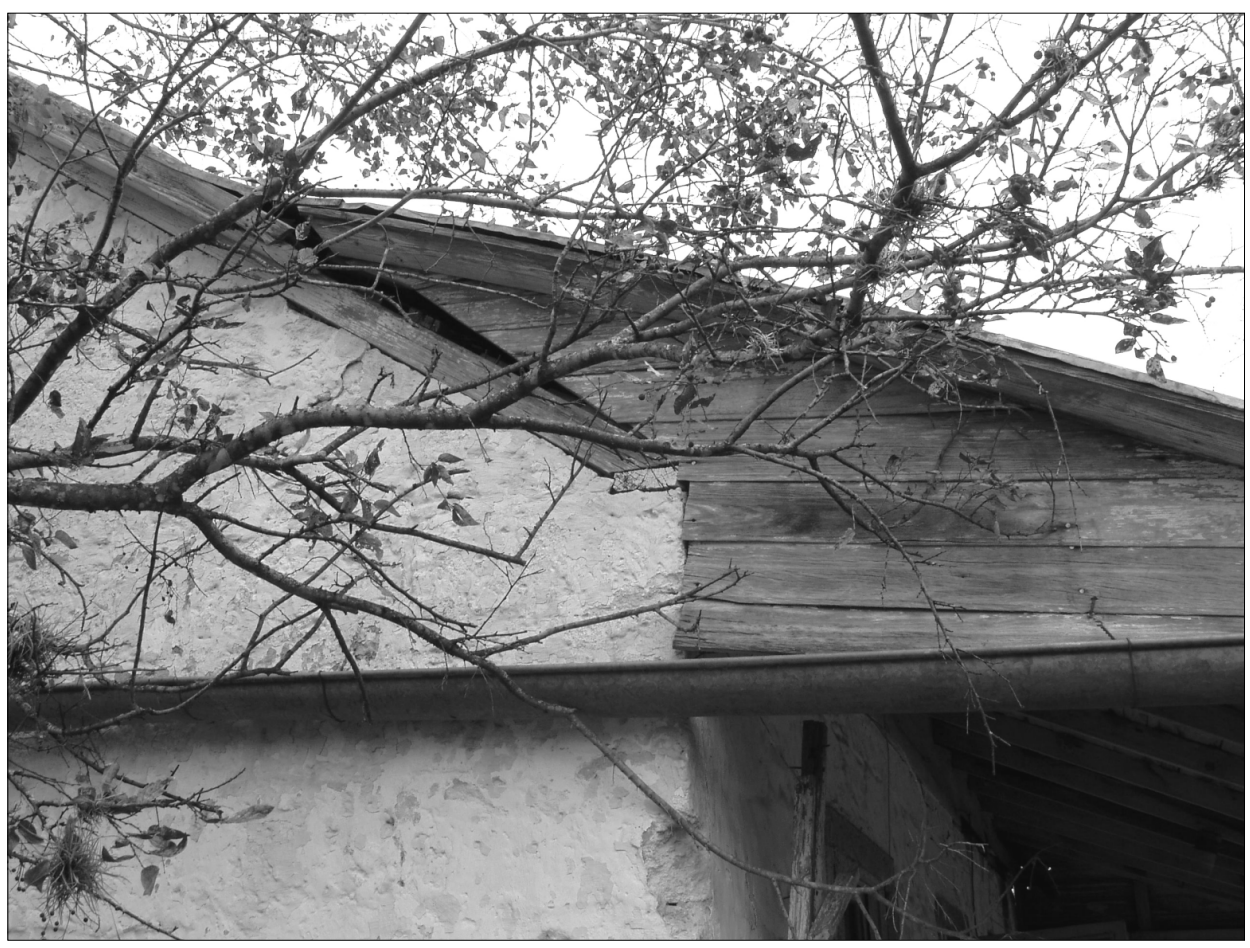

Figure 19. Roof detail of porch addition to the original house. 
The second wood-framed addition was one-unit-deep and ran along much of the south elevation, essentially turning the L plan into a rectangular floor plan (Figure 20). This wood-framed addition was clad in weatherboard siding with a corrugated metal roof. Work on the second addition raised the roof to include an attic space (Figure 21) and extended the floor plan to include two additional rooms including a bathroom.

With the exception of a portion of what is thought to be the original stone structure, all other additions, including the porch, have concrete floors. The entire structure sits on a stone foundation. One interior chimney was built on the north side of the house and interior chimneys were also present in the middle room of the $\mathrm{L}$ plan addition. Finally, a chimney pipe outlet could be seen in the north wall of the westernmost stone addition immediately above a hearth.

Following the survey and the discovery of a 1939 aerial photograph, but before the archival research, it was thought that the original house was built prior to (or in) 1939 because it appeared on the aerial photograph. However, the architectural style of the original structure appeared to be similar to mid- to late-nineteenth-century German stone houses of central Texas, suggesting that the original construction date may have been as early as the late nineteenth century.

\section{Outbuilding 1 (Resource 2)}

Outbuilding 1 is a collapsed, wood-frame structure with a standing seam metal roof. It is located northeast of the main house, north of Outbuilding 2 (Figure 22). It does not retain historic integrity. This building does not appear on the 1939 aerial photograph, therefore, its construction likely postdates 1939.

\section{Outbuilding 2 (Resource 3)}

The second outbuilding is also a collapsed wooden structure with metal roofing (Figure 23). Resource 3 does not retain historic integrity. This outbuilding does appear on the 1939 aerial photo, therefore, at least some elements of it are minimally 50 years old.

\section{Outbuilding 3 (Resource 4)}

This is a third collapsed wood-frame structure with a corrugated metal roof. It is northwest of Outbuildings 1 and 2 (Figure 24). Resource 4 does not retain historic integrity.

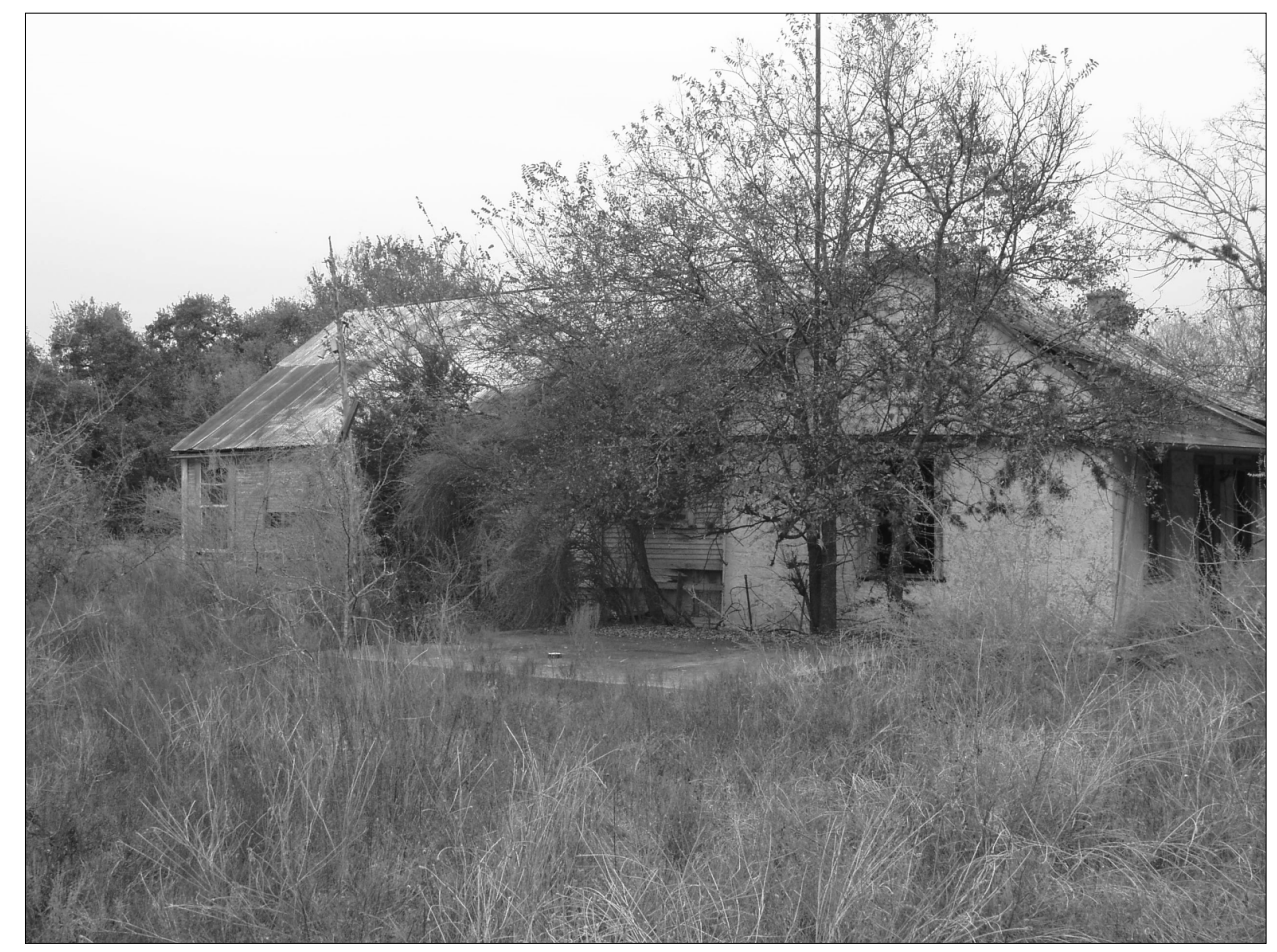

Figure 20. Southern façade of residence (Resource 1). 


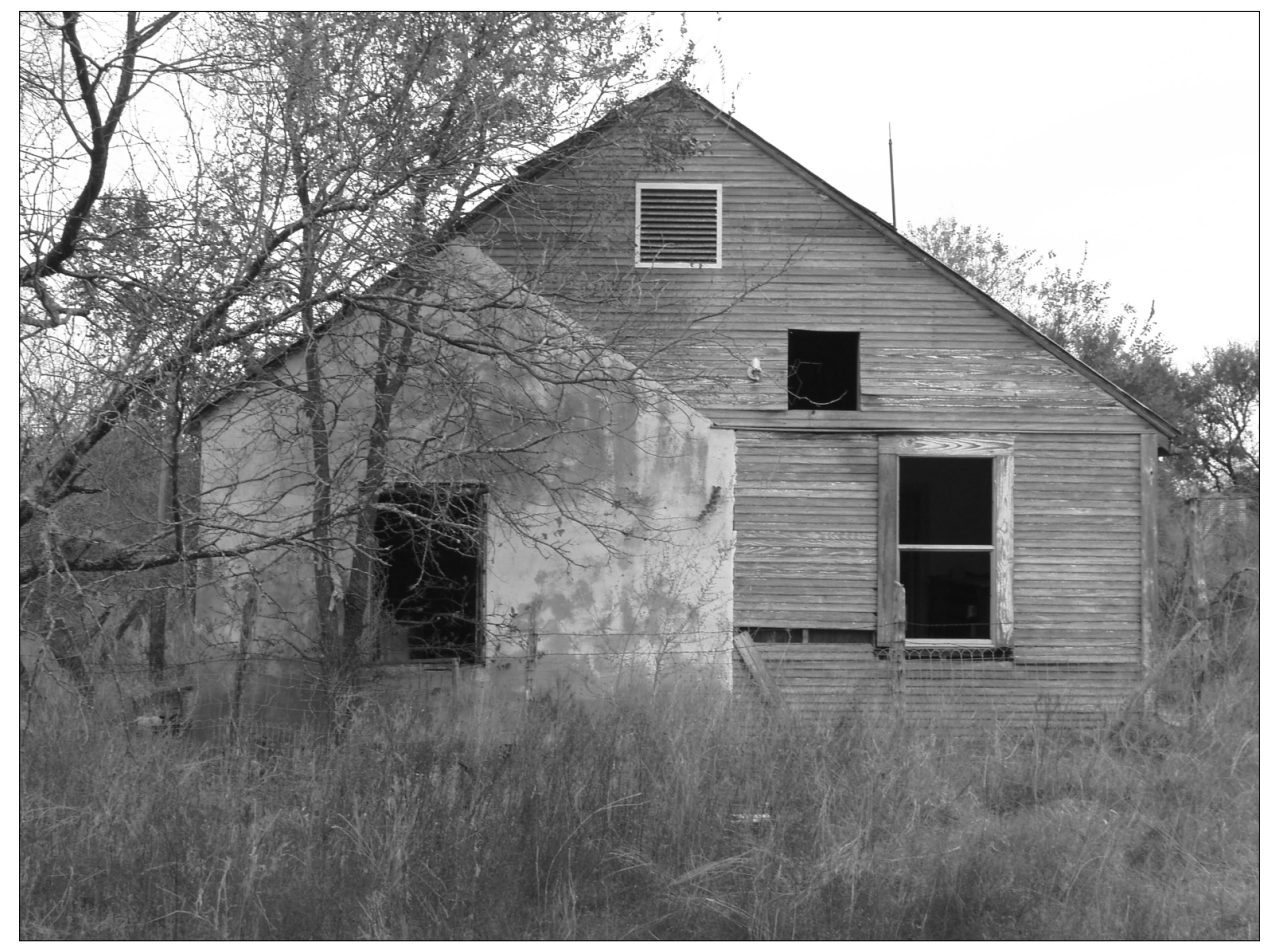

Figure 21. Western façade of residence (Resource 1).

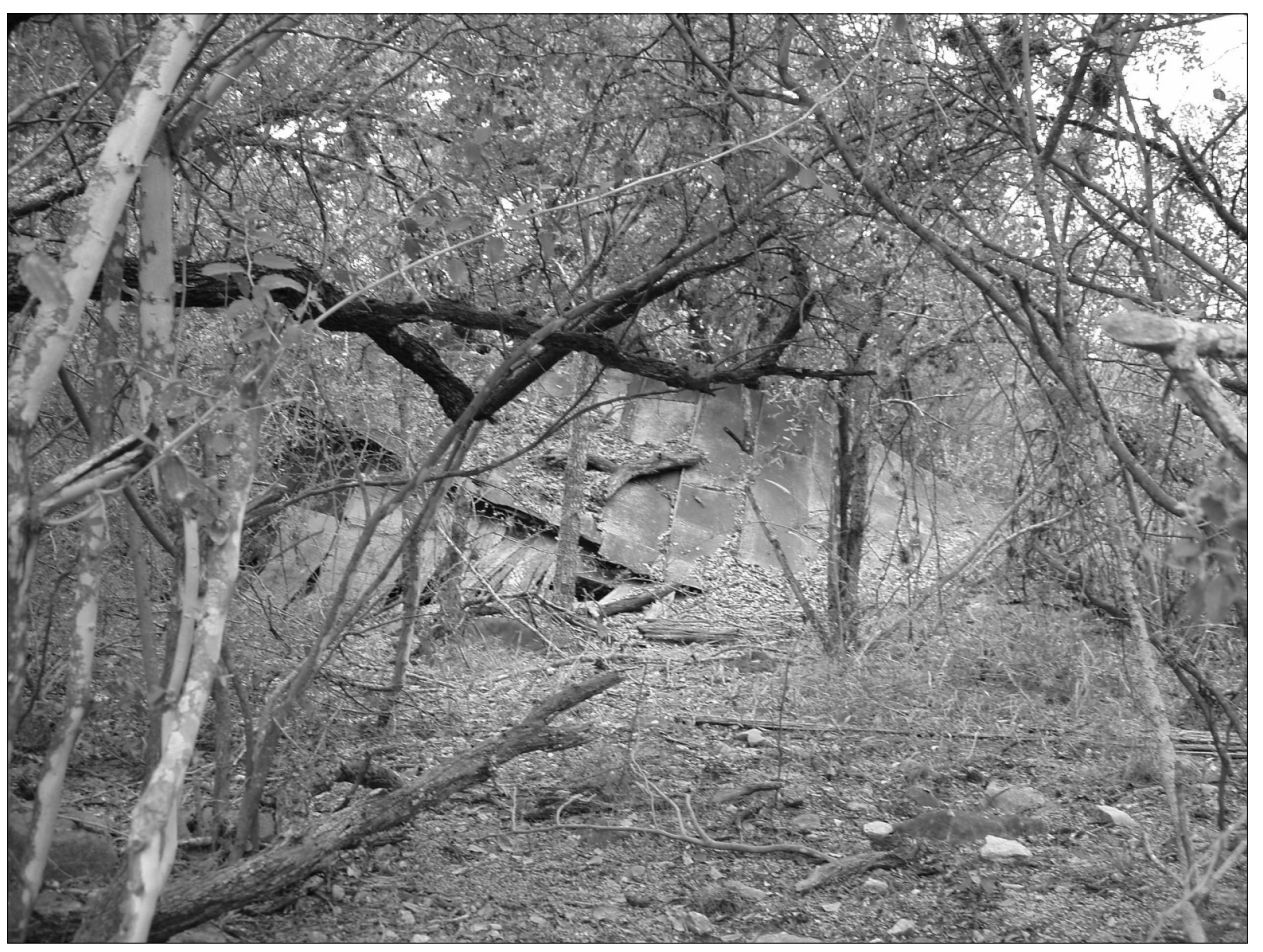

Figure 22. Outbuilding 1 (Resource 2). 


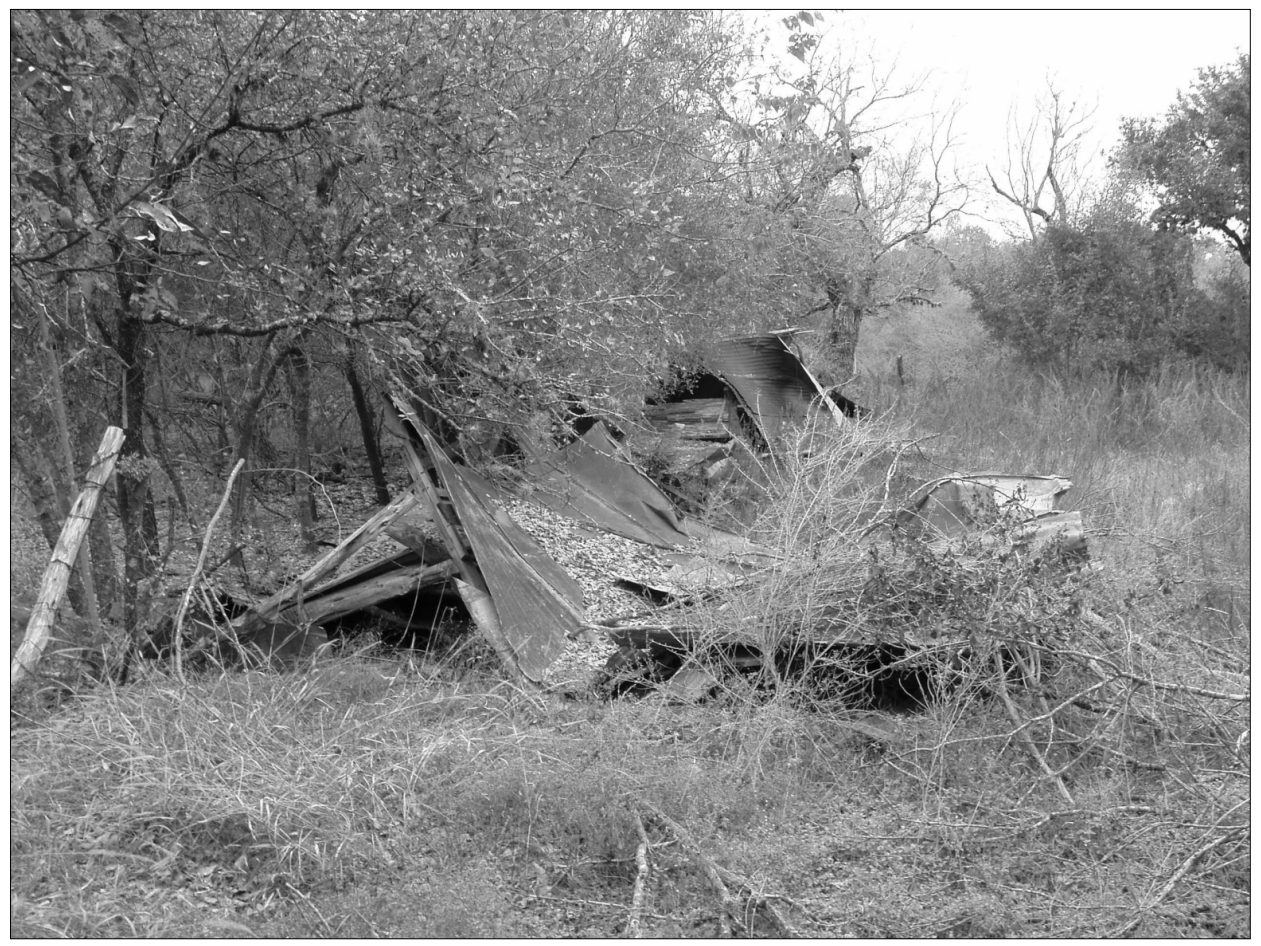

Figure 23. Outbuilding 2 (Resource 3).

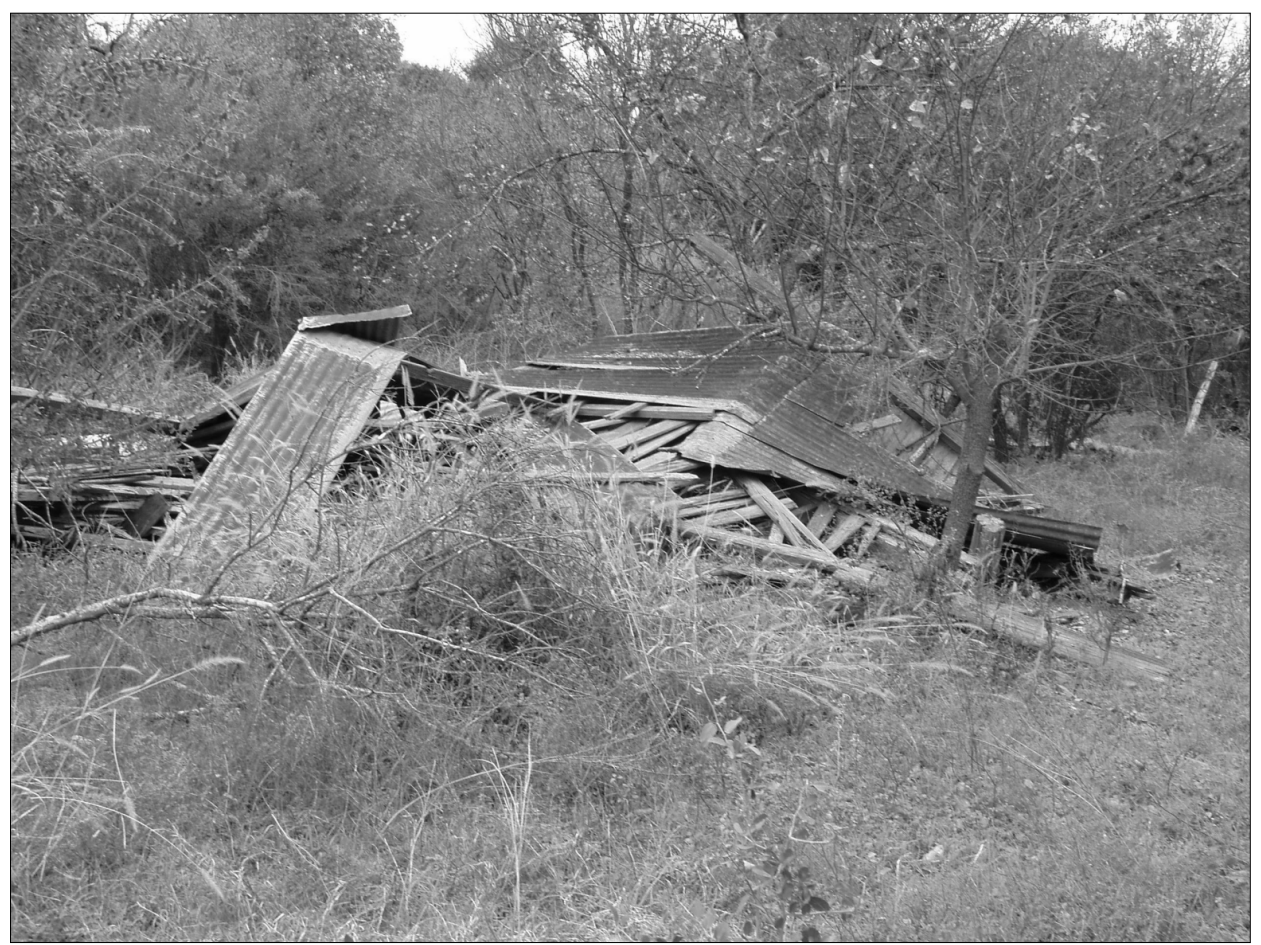

Figure 24. Outbuilding 3 (Resource 4). 
This outbuilding does appear on the 1939 aerial photo so at least some elements of it are minimally 50 years old.

\section{Outbuilding 4 (Resource 5)}

All that remains of Outbuilding 4 is a rock foundation (Figure $25)$. The remnant wood and metal were likely placed in one of the two trash heaps in the backyard of the house. The materials represent the remains of the main barn of the homestead. Resource 5 does not retain historic integrity. This outbuilding does appear on the 1939 aerial photo, therefore, it is likely that the foundation is minimally 50 years old.

\section{Outbuilding 5 (Resource 6)}

This structure exhibits some fine masonry of limestone fieldstone and mortar. There are only two walls, the northern and western, and they are very short with a low corrugated metal roof. This was likely a hog pen (Figure 26). According to Mrs. Babcock, the structure was built by a master stone mason named Andres (last name unknown). Resource 6 is structurally sound and in good condition. This outbuilding does appear on the 1939 aerial photo so at least some of its elements are minimally 50 years old.

\section{Outbuilding 6 (Resource 7)}

Outbuilding 6 is also stone (Figure 27). It has a side-gable roof with wooden shingles filling in the gables on the eastern and western sides and corrugated metal roofing material. The structure is at the end of a sidewalk that leads from the main house, which sits to the north. This structure served as the root cellar for the homestead. The foundation is cement and the interior has a sunken floor. This root cellar was structurally sound and in good condition at the time of the survey. This outbuilding appears on the 1939 aerial photo, therefore, at least some of its elements are minimally 50 years old.

\section{Outbuilding 7 (Resource 8)}

This structure stands west of the main house. This woodframe building is still standing but is in a dilapidated state (Figure 28). Resource 8 does not retain historic integrity. This outbuilding does appear on the 1939 aerial photo and at least some of its elements are minimally 50 years old.

\section{Outbuilding 8 (Resource 9)}

This structure is a wood-frame building with metal sheet siding (Figure 29). Large openings in the front of this

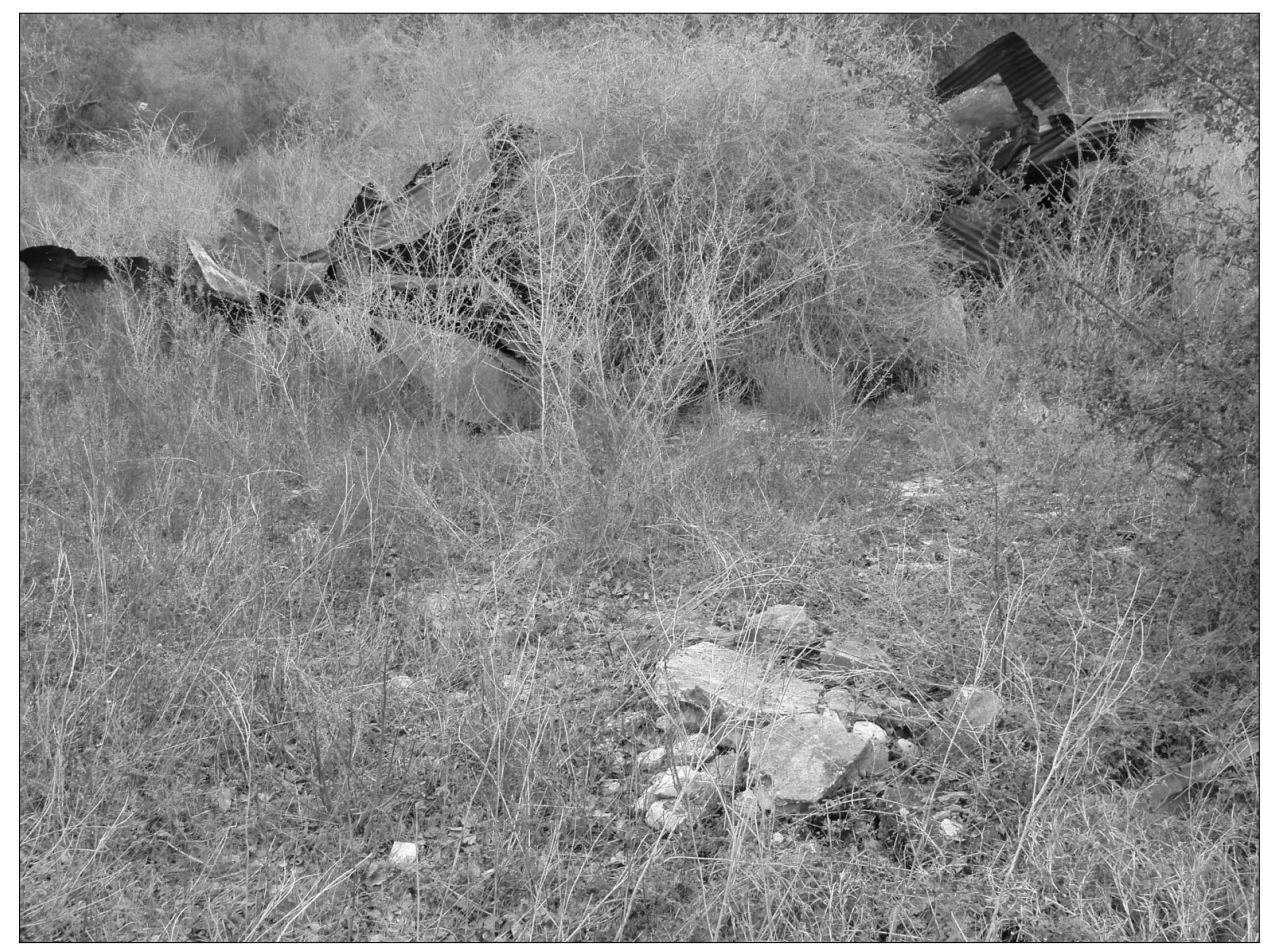

Figure 25. Outbuilding 4 (Resource 5). 


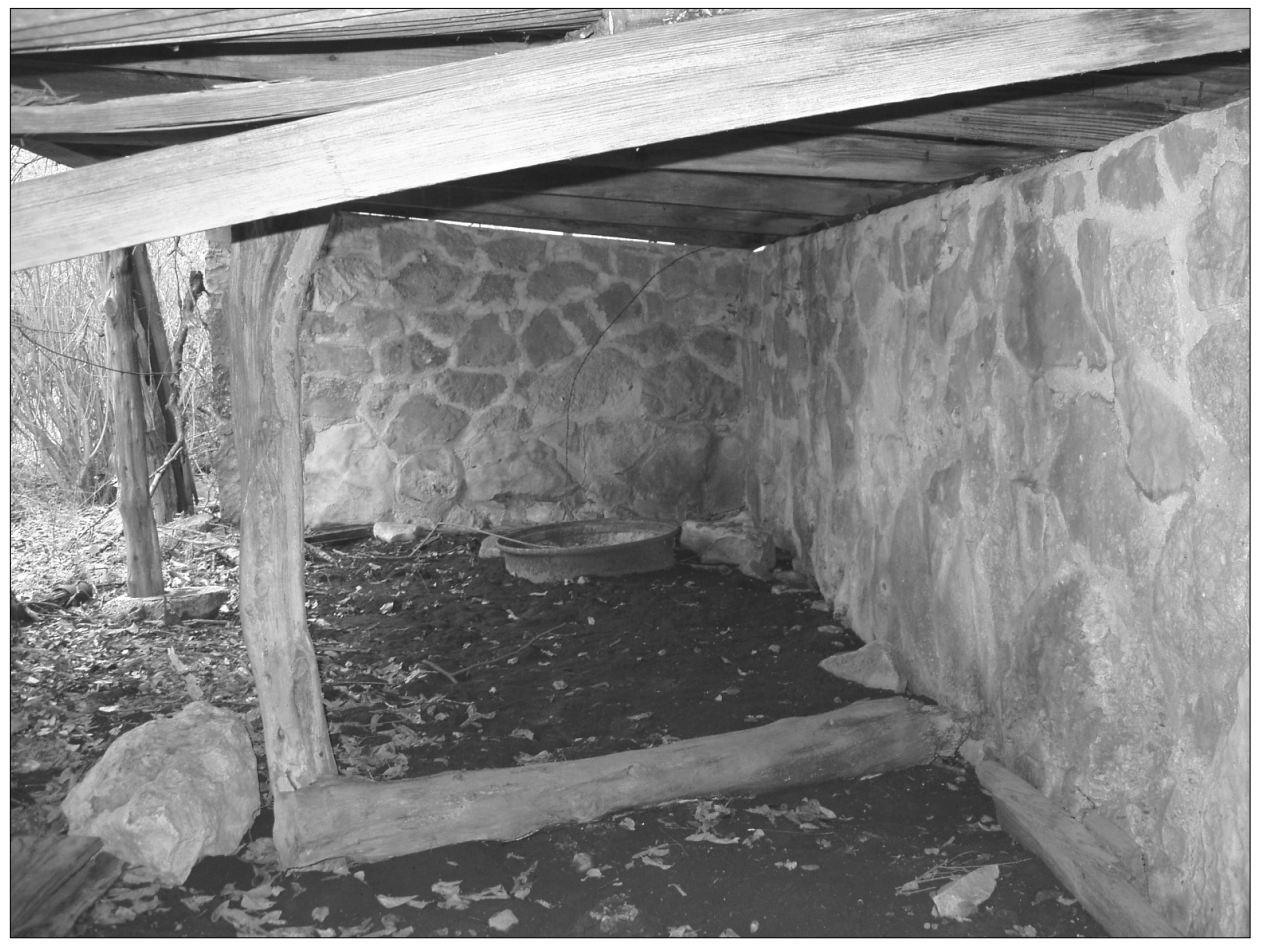

Figure 26. Outbuilding 5 (Resource 6).

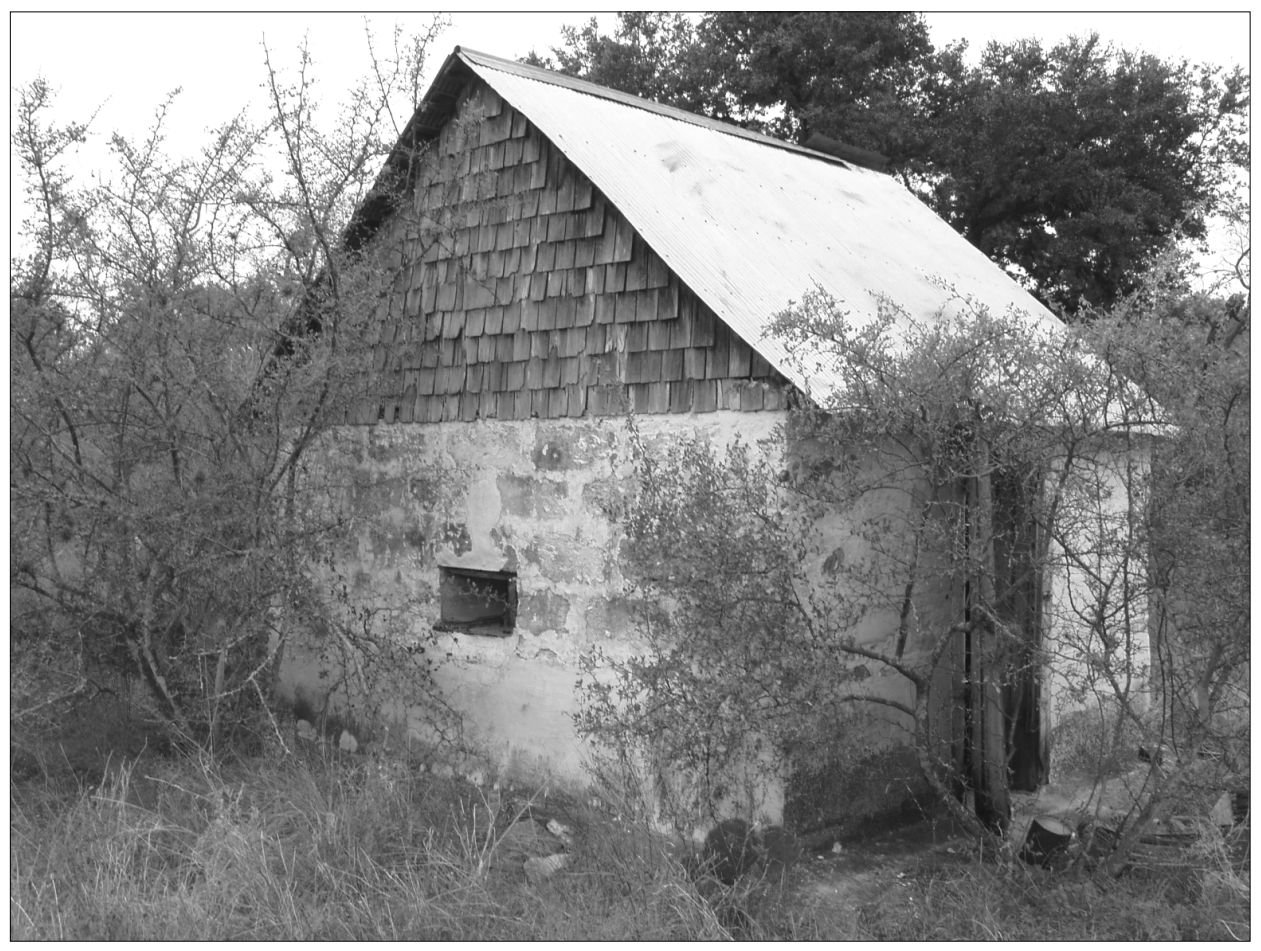

Figure 27. Outbuilding 6 (Resource 7). 


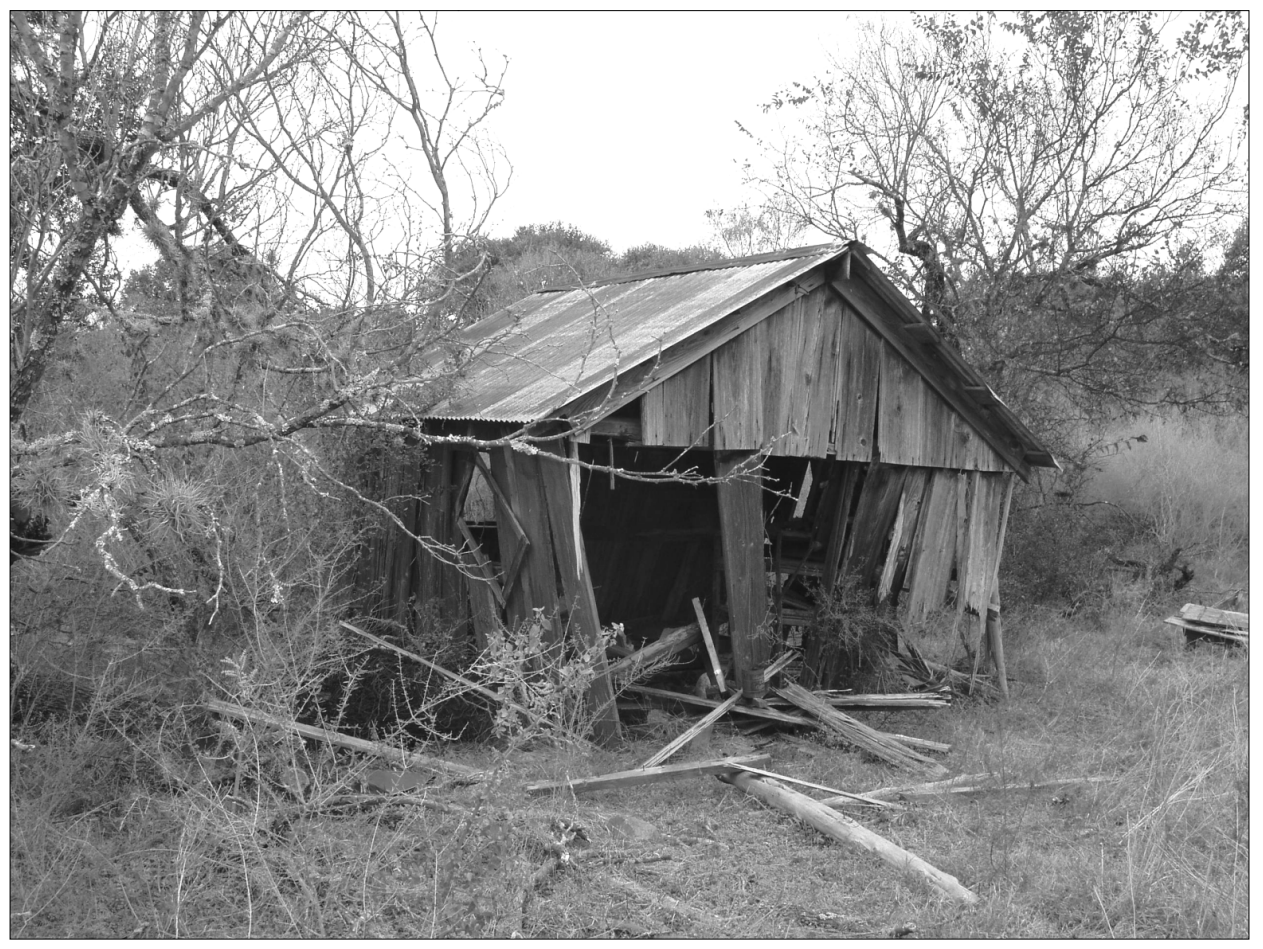

Figure 28. Outbuilding 7 (Resource 8).

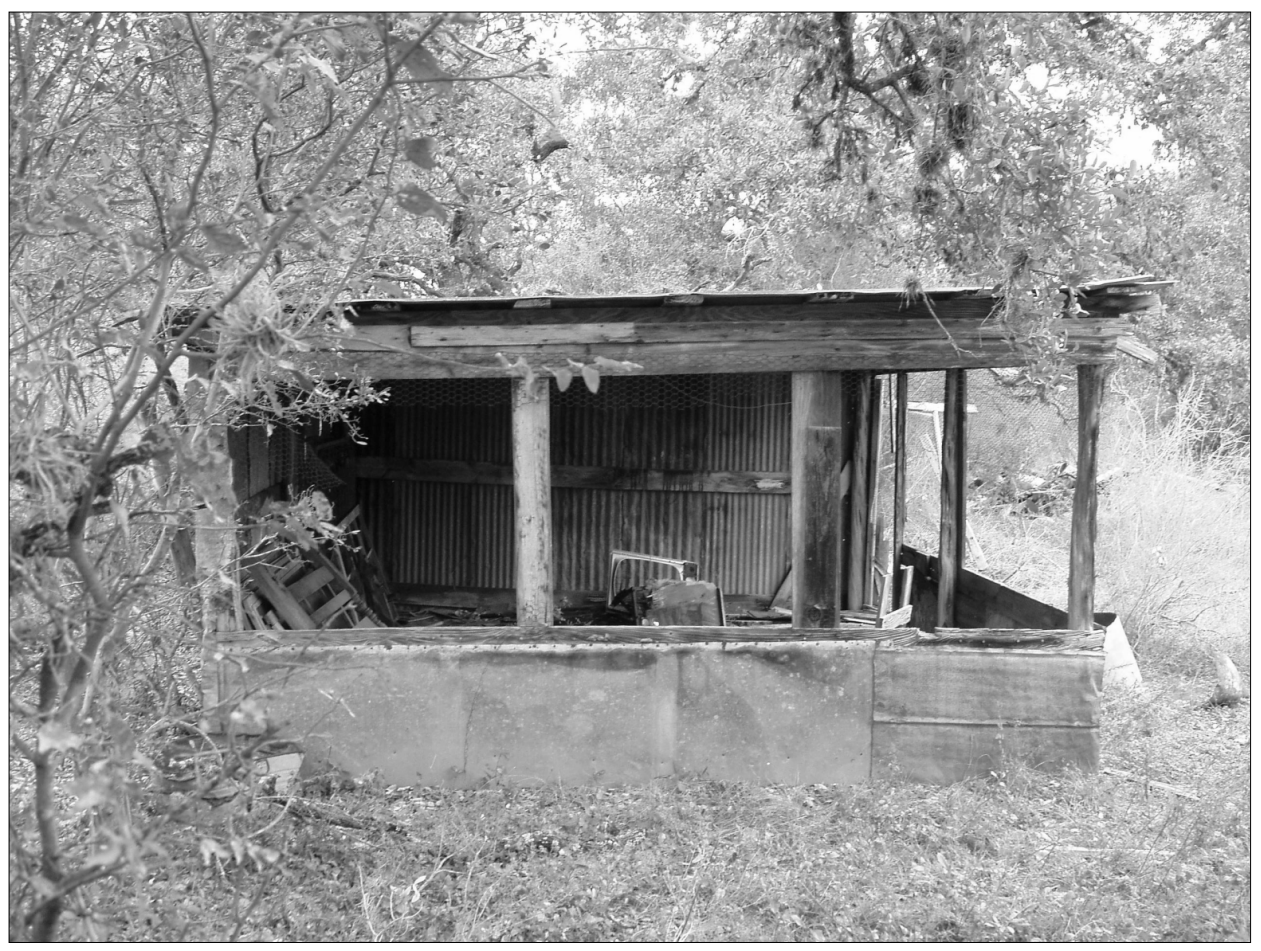

Figure 29. Outbuilding 8 (Resource 9). 
structure may have been covered in chicken wire and the structure used as a chicken coop. Resource 9 does not retain historic integrity. This outbuilding does not appear on the 1939 photograph, therefore, its construction likely postdates 1939 .

\section{Outbuilding 9 (Resource 10)}

This outbuilding is northwest of the main house. It too is a wood-frame structure with a corrugated metal roof (Figure 30). The front of the structure is partially collapsed. Resource 10 does not retain historic integrity. This outbuilding does not appear on the 1939 photograph, therefore, its construction likely post-dates 1939 .

A windmill and a water tank stand to the southeast of the main house (Figure 31). The windmill appears to be present on the 1939 photograph and is, therefore, minimally 50 years old.

At the completion of the pedestrian survey, 10 resources were identified at 41BX1600, one house and nine outbuildings. Based on a historic aerial photograph, the house and six of the outbuildings (Outbuildings 2, 3, 4, 5, 6, and 7) are documented as being at least 50 years old. Three additional outbuildings, a concrete slab, and a cattle chute do not appear on the 1939 aerial and are likely of more recent construction. It is not known whether they are 50 years old. Finally, the aerial photograph also shows four outbuildings that were not noted at the time of the survey. The remains of one of the structures (Outbuilding 10) was identified during a subsequent site revisit. It is not known whether the remaining three structures had permanent foundations or were of more temporary construction; therefore, it is not known whether further site work would have identified their previous locations.

In early January, following the submission of the draft report for THC review, CAR was informed by Raba-Kistner (the client) that the main residential compound had been damaged by fire. On January 11, 2005, CAR staff visited the site to document the degree of damage. During this visit, the ruins of one additional outbuilding were identified on site.

\section{Outbuilding 10 (Resource 11)}

This outbuilding is northwest of the main building at the end of the dirt driveway curving past the stone structure (see Figure 13). The building has been torn down and it is currently identifiable only by pile of lumber and sheets of

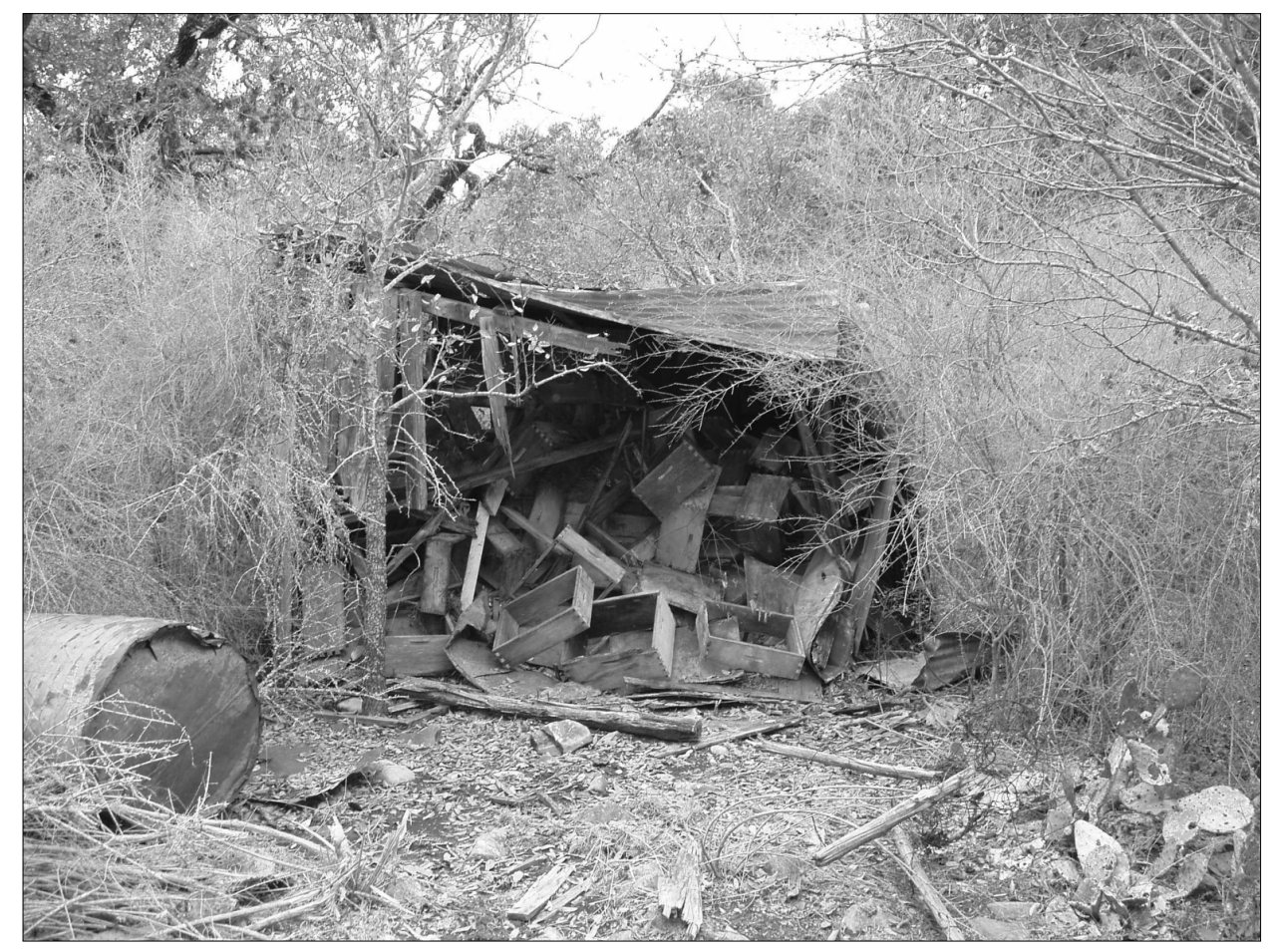

Figure 30. Outbuilding 9 (Resource 10). 


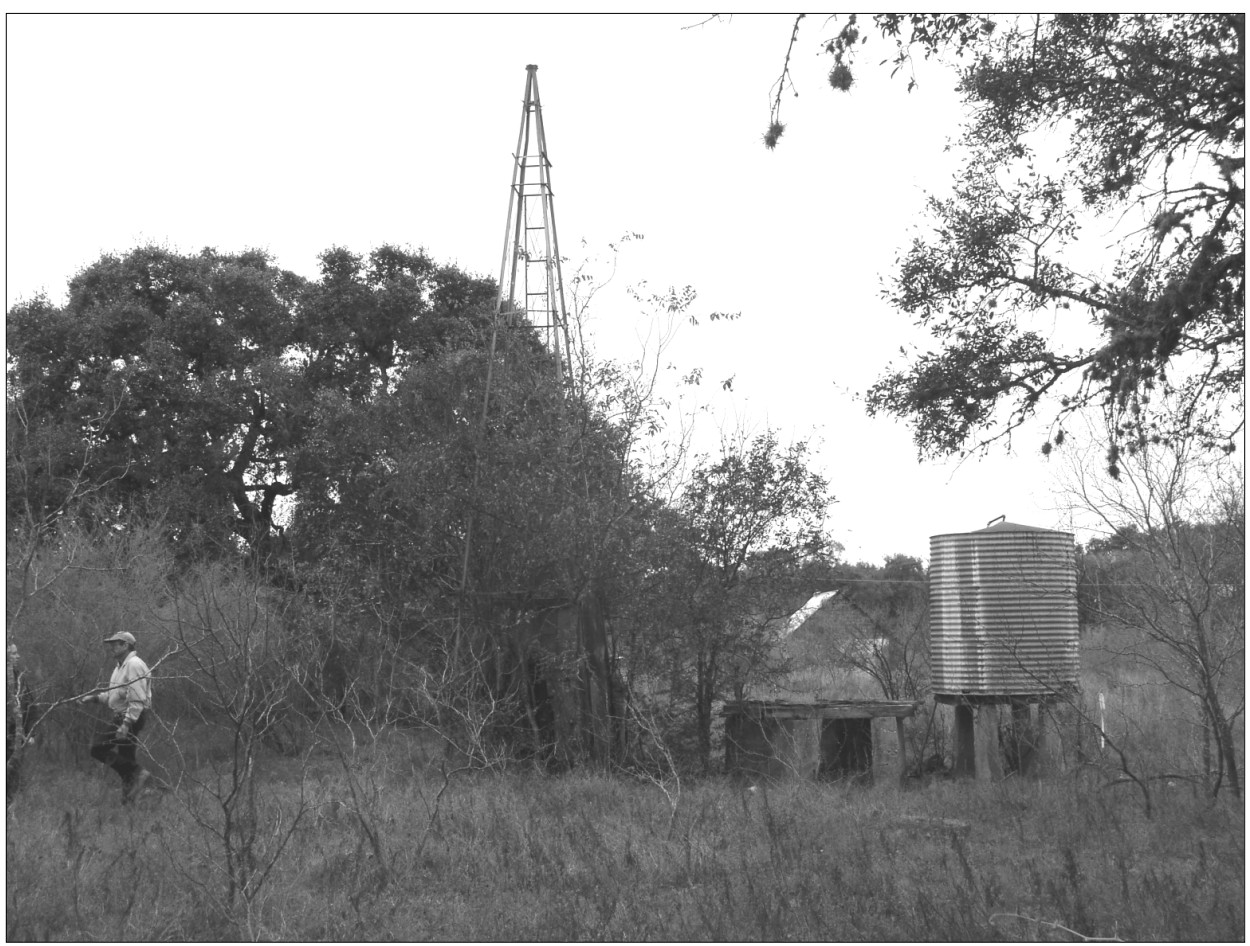

Figure 31. Windmill and water tank southeast of the main house.

corrugated metal that probably served as its roof (Figure 32). According to Mrs. Babcock, this structure was a garage. The structure appears on the 1939 aerial and, therefore, at least some of its elements are minimally 50 years old.

Because the fire damage exposed many of the formerly hidden architectural characteristics of the homestead, in addition to identifying the tenth outbuilding during the revisit, CAR staff were able to examine in more detail the construction materials and sequence visible in the surviving units. The results of these observations, in combination with information from the oral histories, was the basis of the construction history presented in a later section of this report.

\section{Results of Archival Research}

The archival research and the in-person and telephone interviews associated with the oral histories were conducted in February through June, 2005. The archival research focused on the establishment of the ownership history of the property and the construction of the main structure and outbuildings on the homestead.

\section{Site History and Ownership}

Piecing together the ownership of the property was accomplished by investigating the Bexar County Deed Records (BCDR) and through conversations with Mrs. Mildred Babcock (born April 17, 1930), the daughter of Dorothea Naegelin (née Benke). Additional information on the Benke family was obtained from a compilation of family history put together by Ruth Benke for a family reunion (Benke n.d.). Online cemetery records from the Zion Lutheran Cemetery (Zion Lutheran Church of Helotes Archives 2005a, 2005b) and marriage records in Bexar County Vital Statistics (BCVS) at the Bexar County courthouse were used to piece together dates and a history of the family, which allowed tracing deed records more feasible.

The property and homestead was obtained by the Northside Independent School District (NISD) from previous owners in 2002. The individuals that owned the property prior to the NISD were Mildred Babcock, Dorothy N. Reed Joy, Leroy R. Kneupper, Frances E. Richter, Calvin W. Kneupper, Lyndia D. Sachtleben, Margaret P. Kneupper, and Ralph J. Kneupper. The property was passed on from Dorothea 


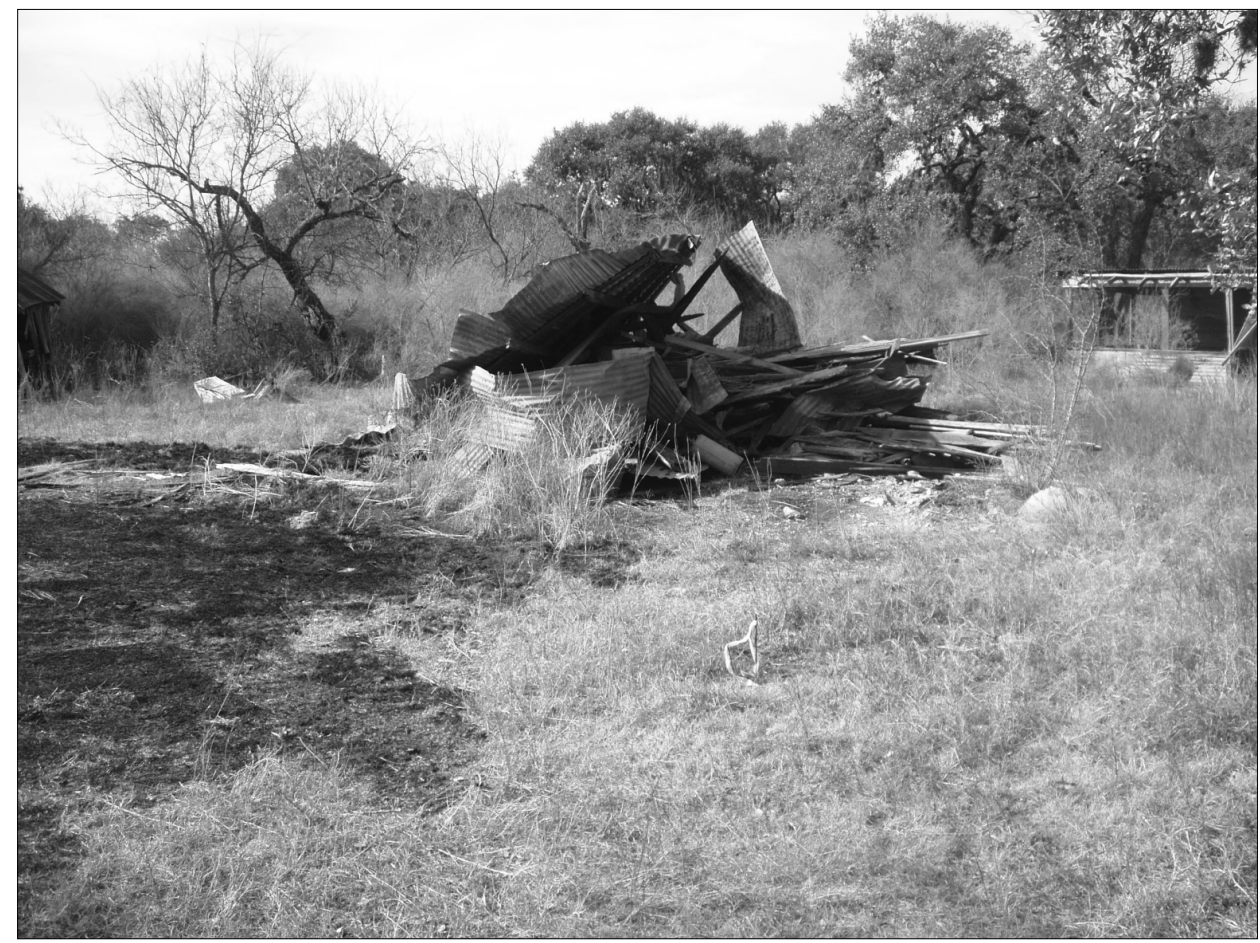

Figure 32. Outbuilding 10 (Resource 11).

Naegelin to family members in 1997 in the form of a special warranty deed (BCDR 9703:2274) after her death in 1984. The property was divided among family members as follows: Mildred Babcock 1/3, Dorothy N. Reed Joy 1/3, Leroy R. Kneupper 1/18, Frances Richter 1/18, Calvin W. Kneupper 1/18, Lyndia D. Sachtleben 1/18, Margaret P. Kneupper 1/ 18, and Ralph J. Kneupper 1/18.

Dorothea (Dora) Benke was born in 1898 in Helotes, Texas. She was the only girl in a family of seven children (see Appendix A). She married Frank Naegelin in 1924. In 1984, Dora Naegelin died at the age of 85. Frank Naegelin was born in 1894 and died in 1973. Dora Benke was the daughter of Alex and Elisa Benke, who passed the property on to her in 1936. At the time, the property consisted of 190.12 acres of land (BCDR 1525:394). The 190.12 acres included 20 acres of land deeded to Elisa Benke (née Biering) on September 13, 1890, from F. A. and M. L. Biering (BCDR 65:365-371; Figure 33) and 170.12 acres of land deeded to Alex Benke on June 6, 1888 (BCDR 73:5).

Alex and Elise Benke were the original residents and builders of the homestead (Mildred Babcock, personal communication 2005). Alex Benke married Elise Biering in 1888 (BCVS 103:9382; Figure 34). Elise Biering was born in 1861 and died 1941. Both Alex and Elise Benke are buried in the Zion Lutheran Cemetery in Helotes. Alex J. Benke, the eldest of 13 children, was born in 1859, his parents were Alexander Benke (Benko) and Anna Elise Schmidt (Figure 35; Appendix A). Alexander Benko was born in Hungary in 1824 and migrated to the U.S. during the mid 1800s. Anna Elise Schmidt was born in Hamburg, Germany in 1835 (Genealogy.com 2003). They lived on the property in the area of present-day Kyle Seale Ranch, on Kyle Seale Road off Loop 1604, where they were both buried (Mildred Babcock, personal communication 2005).

On a 1927 quadrangle map of Bexar County, the name of A. Benke is shown in the location of the property and it appears the homestead would have been located on the 190.12 acres of land that was deeded to Dorothea Naegelin in 1936 (see Figure 33). The three different survey areas, Perry Davis Survey No. 267, H. A. Langwell Survey No. 350, and A. Biering Survey No. 38 that make up the description of the 1936 property are identified on a General Land Office map of Bexar County dated September 1832. 


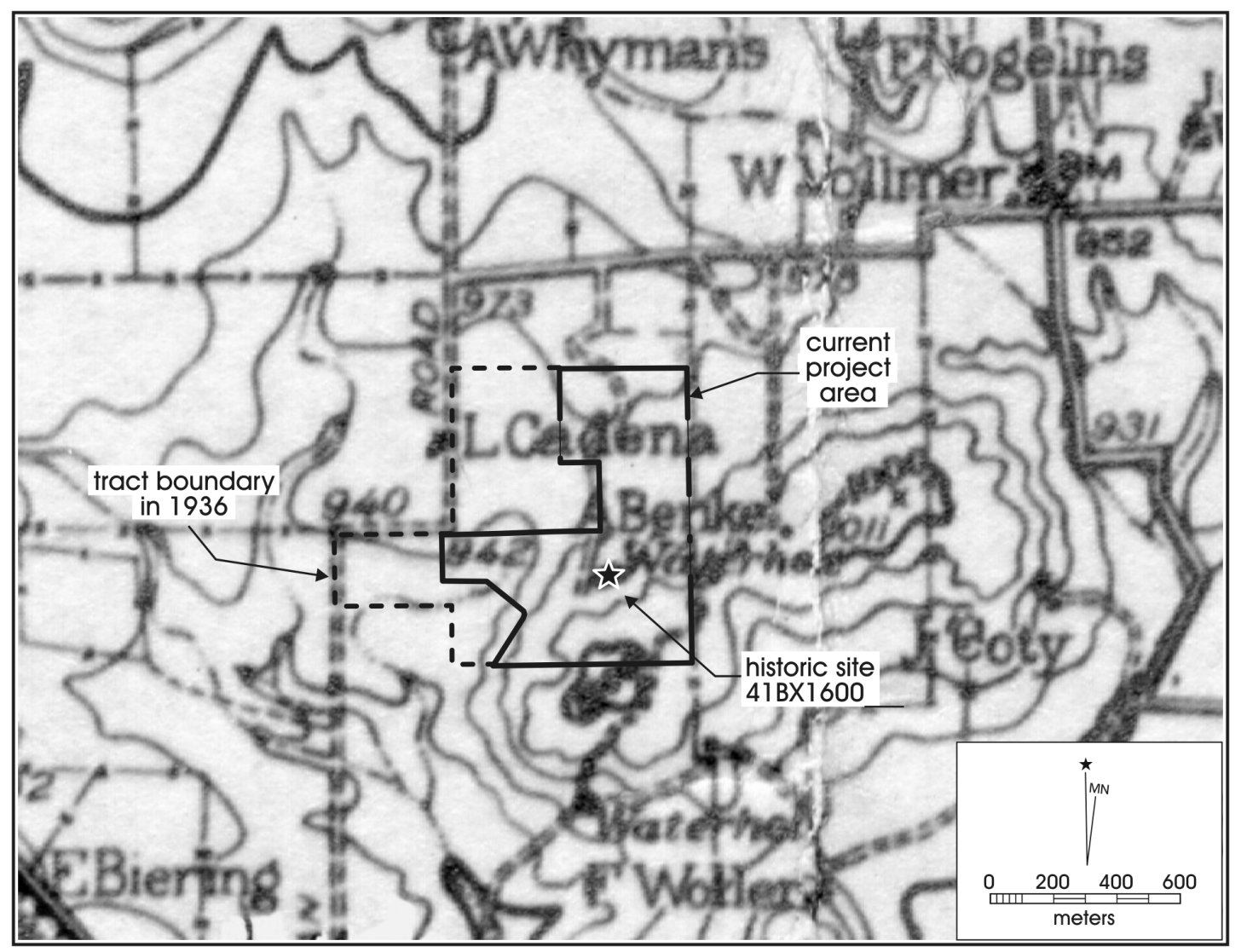

Figure 33. The 1927 Helotes, Texas, USGS quadrangle map showing the location of the 190.12 acres deeded to Dorothea Naegelin in 1936. Note A. Benke is shown as owner of the property.

\section{Oral Histories}

Oral histories from individuals about the ownership of the homestead property and land use were a second aspect of the archival research. A list of questions aimed at obtaining as much information as possible about the ownership history of the homestead and its land use was prepared prior to interviews. Conversations with Mrs. Mildred Babcock and Mr. Leroy R. Kneupper were especially insightful regarding the history of the Naegelin homestead. Mildred Babcock is the daughter of Dorothea and Frank Naegelin, former owners of the property. Several phone calls and formal meetings with Mrs. Babcock aided tremendously in investigating the history of the property.

The homestead was built by Alex and Elise Benke sometime after their marriage in 1888. Bexar County deed records confirm that the property that was given to Dora Naegelin was originally obtained by Alex and Elise in 1888 and 1890 .
Both Alex and Elise Benke were born in Bexar County. Conversations with Mildred Babcock revealed that Dorothea and her siblings were born on the property and delivered by a neighboring midwife, a member of the Woller family.

According to Mrs. Babcock, there is one unmarked grave on the property that belongs to Edwin Benke, the brother of Dorothea. Edwin was born in 1891 and died in 1905 of diphtheria. A headstone was made and placed at the Zion Lutheran Cemetery in Helotes; however, the body was never moved to the cemetery after the placement of the headstone. Mrs. Babcock states that the unmarked grave on the Naegelin property is located northeast of the house at the bottom of the hill, on the southern edge of the agricultural field.

The activities that took place on the homestead included beekeeping, cattle and hog raising, and some agriculture. After World War I, Frank Naegelin took up the activity of beekeeping, possibly in Outbuilding 9 where several bee 


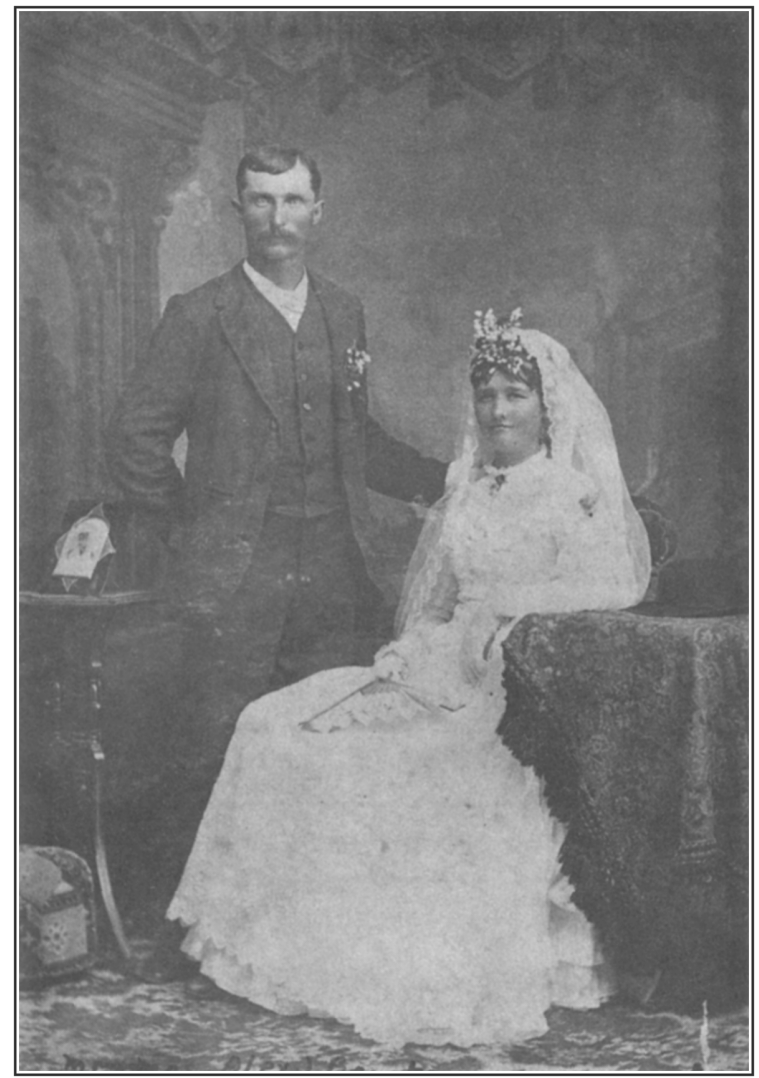

Figure 34. Wedding portrait of Alex J. Benke and Elisa Biering Benke (no date). Courtesy of Mildred Babcock. boxes were present in 2005 (see Figure 30). Cattle, turkeys, chickens and hogs were raised on the property as well. The hogs were kept in Outbuilding 5, a limestone block pen that was still standing in January 2005. The pen was constructed by a stone mason from Helotes by the name of Andres (last name unknown) when Mrs. Babcock was a teenager. The hogs were raised for household consumption. One of the outbuildings no longer present on site was used as a smokehouse where venison was dried and smoked. This building was not present during the 2005 visit but is visible on the 1936 aerial photograph. In a photo obtained from Mrs. Babcock, the smokehouse was located immediately to the northwest of Outbuilding 6 (Figure 36). Mrs. Babcock also recalled a milk house used by her grandparents, another structure no longer standing. The concrete slab, south of the original portion of the house, covers a cistern/septic tank.

Although indoor plumbing was added to the house, a privy was always present outside of the fenced yard, south of Outbuilding 6. No sign of the privy was visible at the site. A household dump area was not located during the survey or subsequent revisits, and according to Mrs. Babcock, much of the materials used were recycled rather than discarded on site.

Cattle were also raised on the property and the field where they grazed was near the stock tank, northwest of the main house (Mildred Babcock, personal communication 2005).

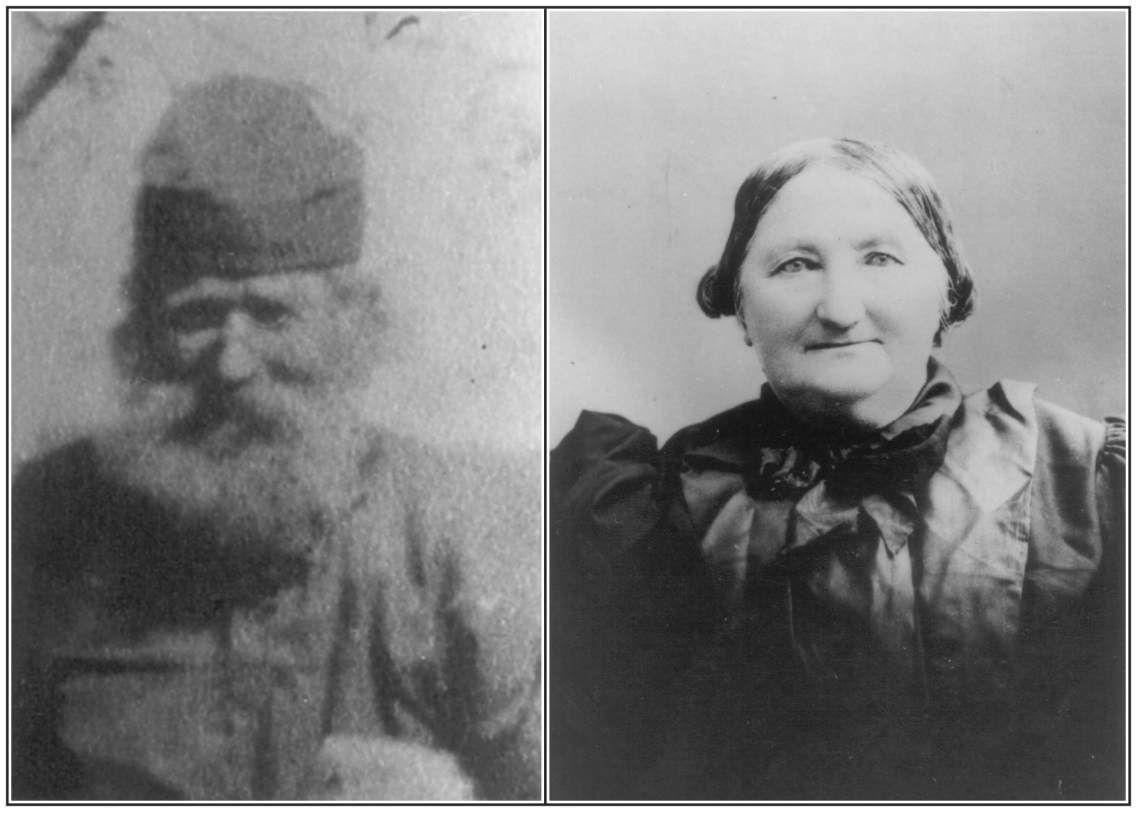

Figure 35. Alexander Benke (Benko) and Anna Elise Schmidt, parents of Alex J. Benke (no date). Courtesy of Mildred Babcock. 
The only agricultural activity that took place on the property was food grown for the cattle. The field used for growing primarily oats was located just northeast of the homestead.

Two photographs were obtained of the homestead from Mildred Babcock. It appears that the front porch originally had railings (Figure 37). A second photo shows one of the outbuildings located in the northeastern portion of the property (Figure 38). Dorothea Naegelin was the last person to reside in the homestead and it was vacated around 1982, after she became ill and went to live with her daughter, Dorothy Reed (née Naegelin; born August 1, 1938).

\section{Construction History of the Homestead}

Figure 39 shows a floor plan of the principal stone-built portion of the homestead. While a sketch map of the homestead was made during the post-fire visit of the site, it was hoped that a more detailed map could be made prior to the revision of the draft report. Unfortunately, by the time the CAR staff returned on March 28, 2005, to complete a measured floor plan of the stone-built structures, the structures had been demolished because they represented a safety risk during planned asbestos abatement activities (see Appendix B). Therefore, only measurements of the imprints of the walls could be obtained.

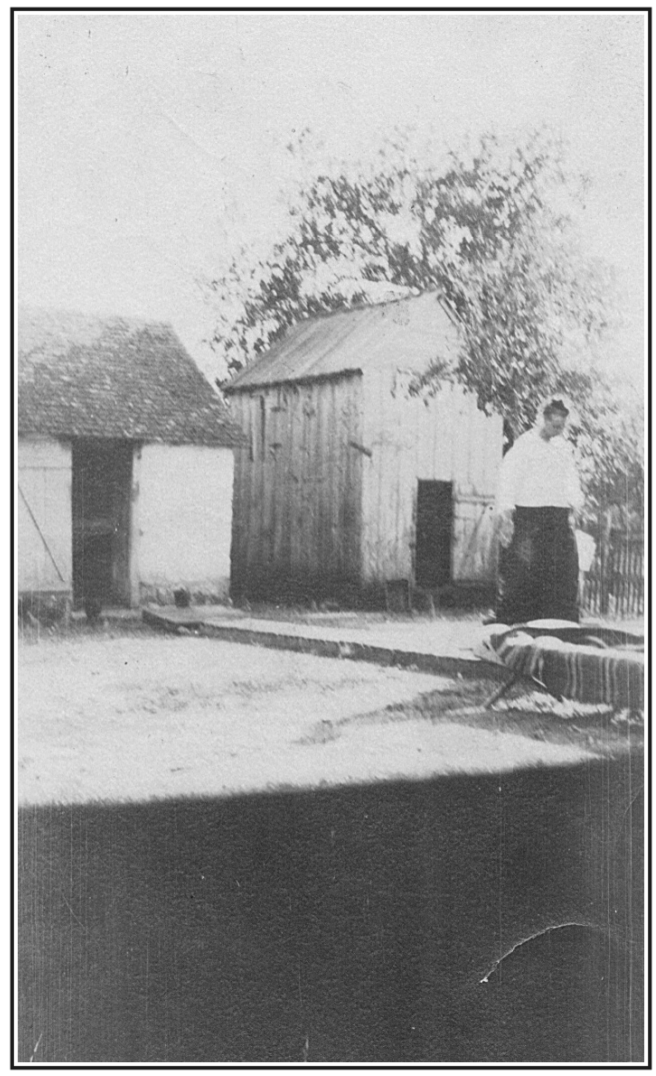

Figure 36. Root cellar (Outbuilding 6) and smokehouse on the Benke/Naegelin property, Elise Biering Benke at far right (no date). Courtesy of Mildred Babcock.

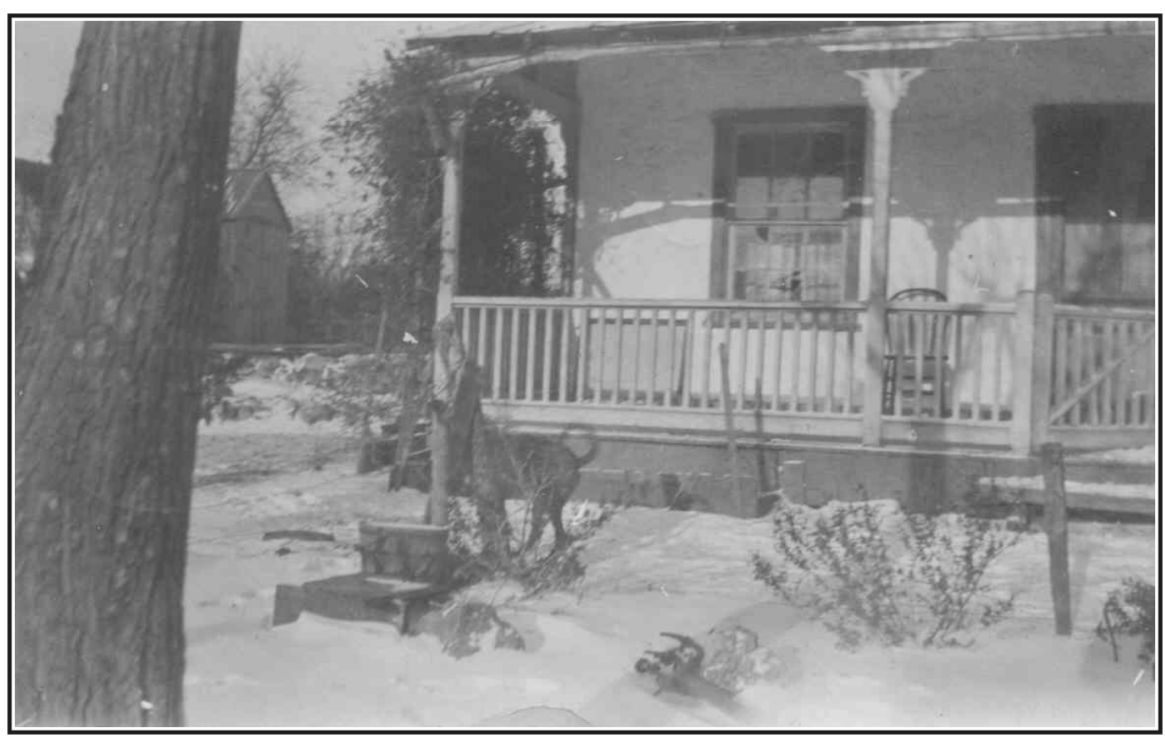

Figure 37. Front porch of the Benke/Naegelin homestead (no date). Courtesy of Mildred Babcock. 


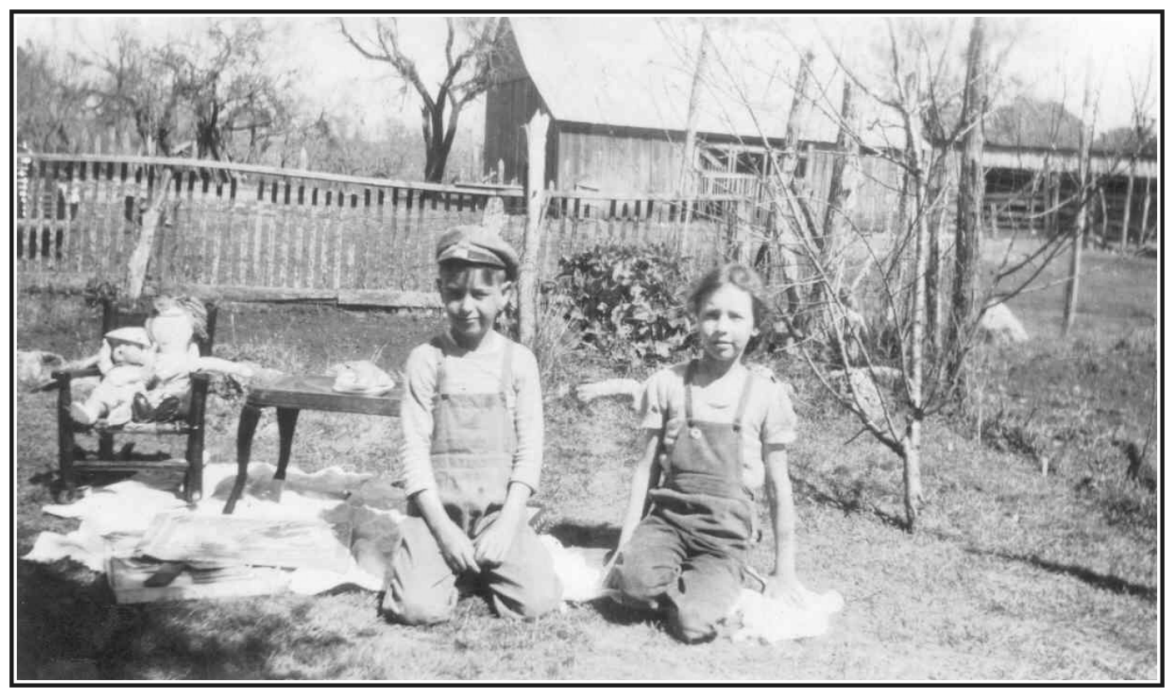

Figure 38. Northeastern portion of the Benke/Naegelin homestead property (barn in background; James Benke, left; Dorothy Naegelin, right; no date). Courtesy of Mildred Babcock.

Nonetheless, based on photographs taken during the various visits to the property, a careful examination of wall construction and abutment lines suggests that there may have been as many as three phases of construction of the main stone house. Judging from an obvious abutment line adjacent the front door (Figure 40), and the presence of a concrete slab that covered the southern portion of this room and extended outside and served as the floor of the patio, it appears that the homestead may have originally consisted of a single wooden-floored room that made up the northern half of the main structure (Original Structure in Figure 39). The original one-room stone cottage measured approximately $4.2 \mathrm{~m} \times 5 \mathrm{~m}$ on the inside. A chimney flue and chimney emerging from the north wall of this room suggest that it may have been heated by a potbelly stove. The north wall of this room contained a window, and it is possible that the east wall of this room contained a doorway that was later partially modified to serve as a window when the size of the room was extended to the south at the abutment line noted adjacent the present doorway (Figure 41).

The first addition (Addition 1) appears to have been added soon after the construction of the original building, judging from the similarity in construction styles, and the style of cut stone. It is likely that the cement slab was added much later and the original floor was wood planks. Addition 1, measuring approximately $3.5 \mathrm{~m} \times 5 \mathrm{~m}$, transformed the original, nearly square structure into a rectangular room with nearly double the floor area. Given that the oldest of the children, Theodore Benke, was born in 1891 (see Appendix A), it is possible that this first addition would have been built shortly before or after his birth. Keystones were present on all of the windows and doors in the original room and in Addition 1 (Figure 41). The window framing in Addition 1 was secured with forged nails (Figure 42) and the limestone blocks were of higher quality.

Addition 2 abutted the west wall of the original room and extended to the west (Figure 39). It measured approximately $4.2 \times 4.7$ meters on the inside and had doors in all four walls. Neither of the doorways in the northern and southern walls had keystones, although the eastern and western wall doorways were capped with keystones. The absence of keystones in two of the doorways may be reflective of distinct craftsmanship and a later construction given the wire nails that held the wood door framing in place.

Addition 3 abutted the western wall of Addition 2 and abutment lines were clearly visible along the interior corners and along the outside of the southern wall (Figure 39 and Figure 43). This room measured approximately $6.3 \times 4.2$ meters on the inside and had windows in its northern and western walls and two doors along the southern wall. A cooking hearth was present along the north wall of the addition (Figure 44) and an inset niche was located in its west wall immediately next to the window (Figure 45). The eastern wall doorway incorporated a keystone into its construction, although it appears to have been replaced at 


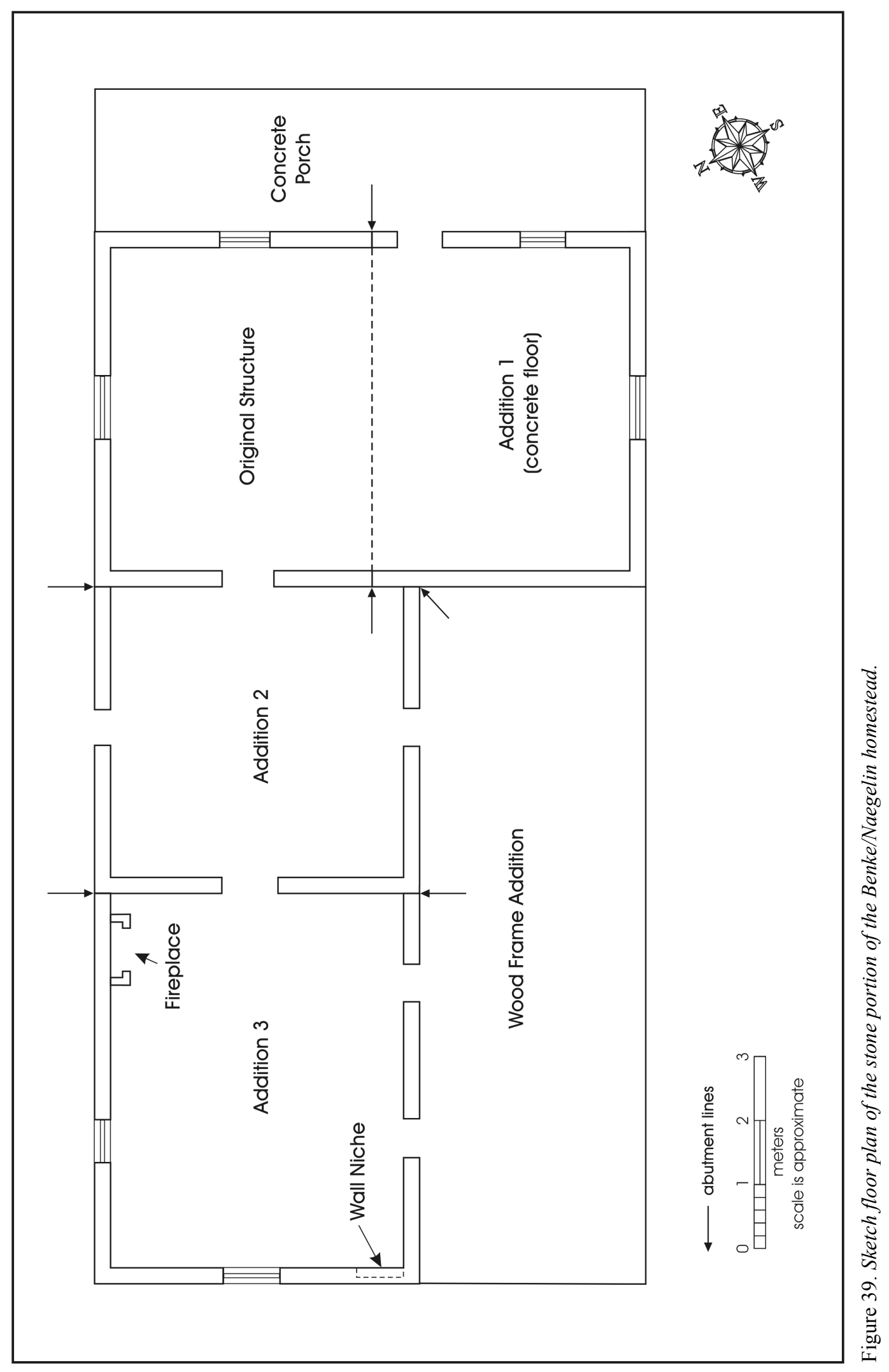




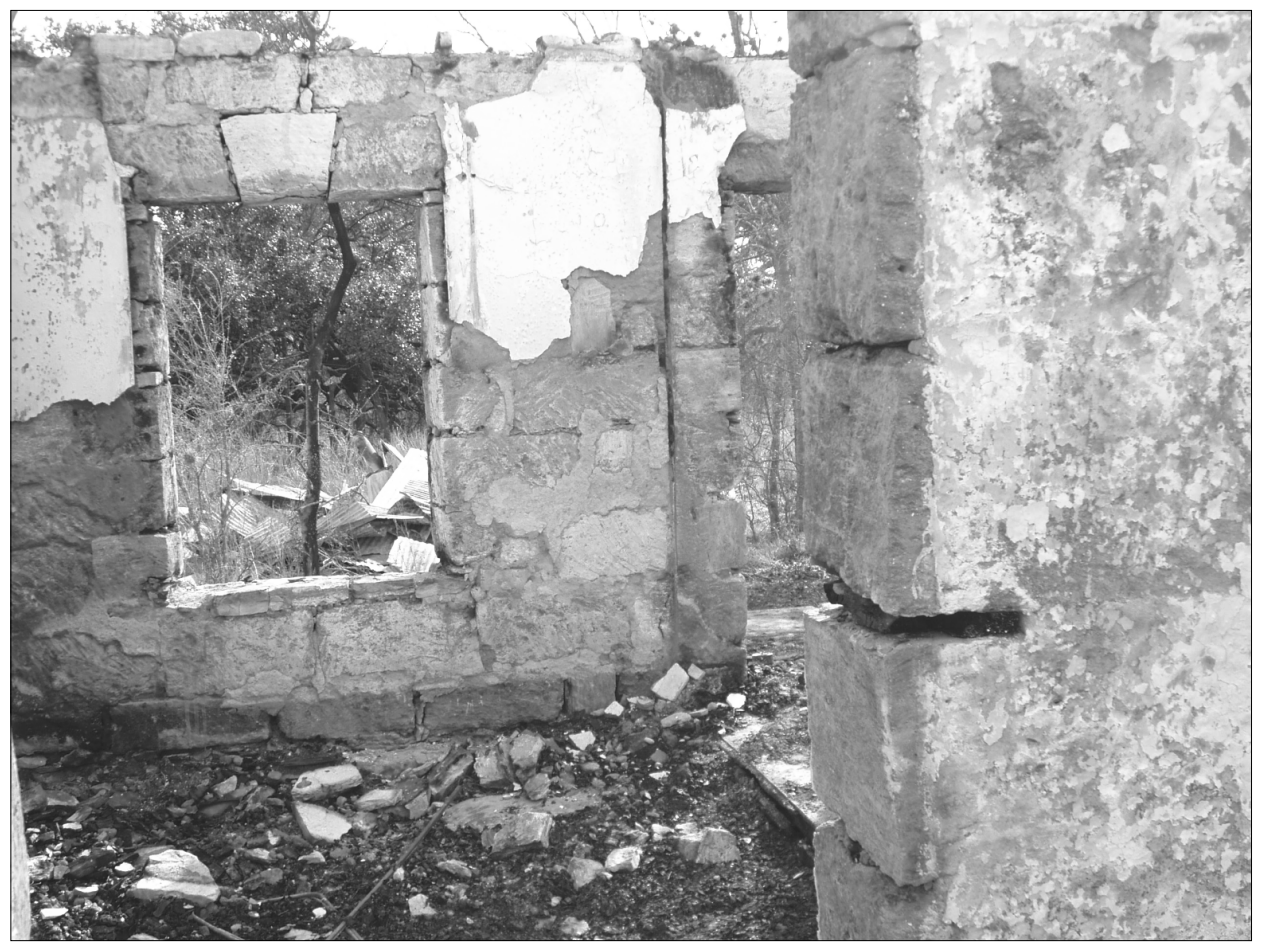

Figure 40. Abutment line and concrete floor of Addition 1 of Benke/Naegelin homestead.

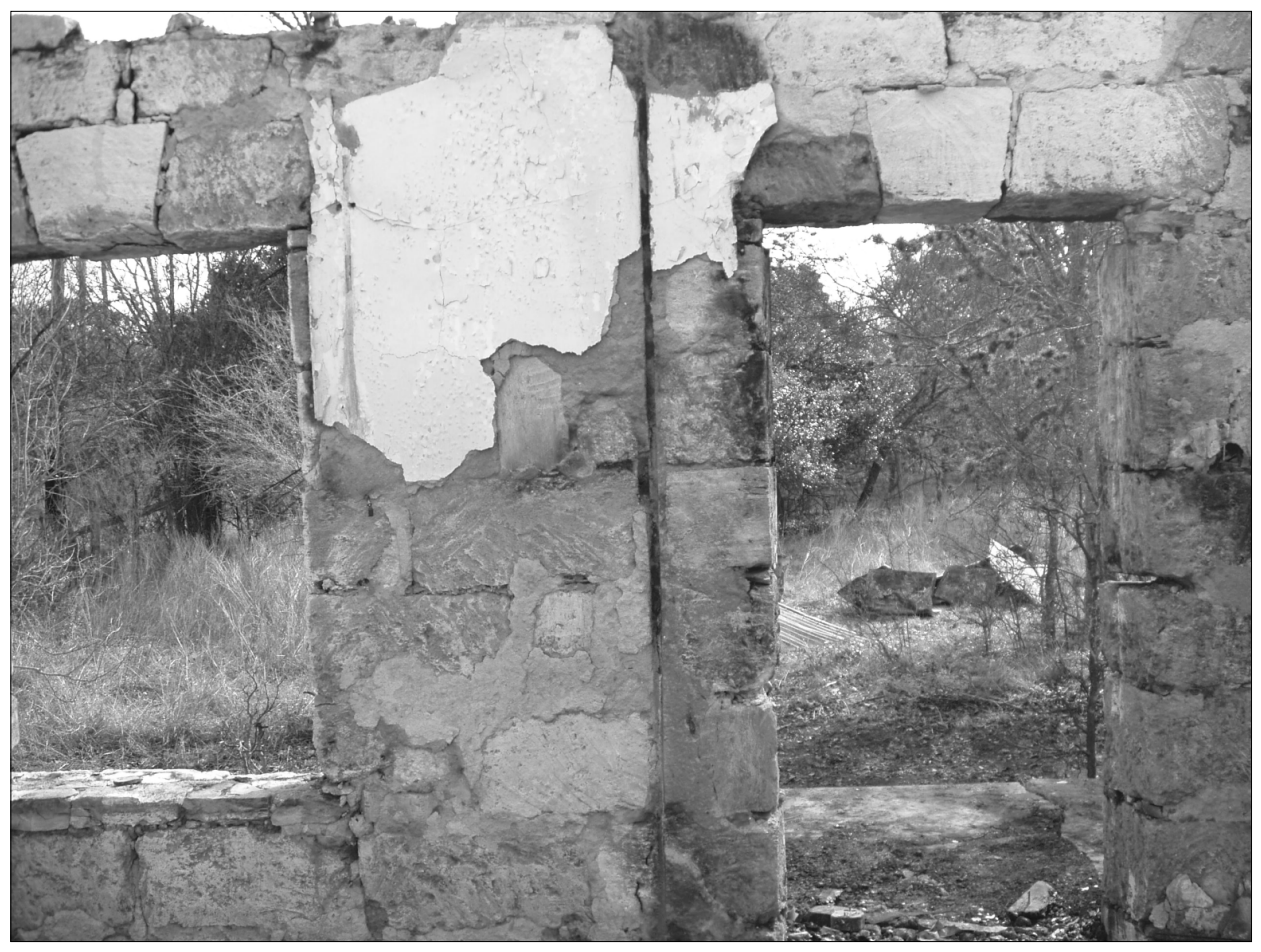

Figure 41. Inside of original portion of homestead employing keystone above the window and doorway (facing west). 


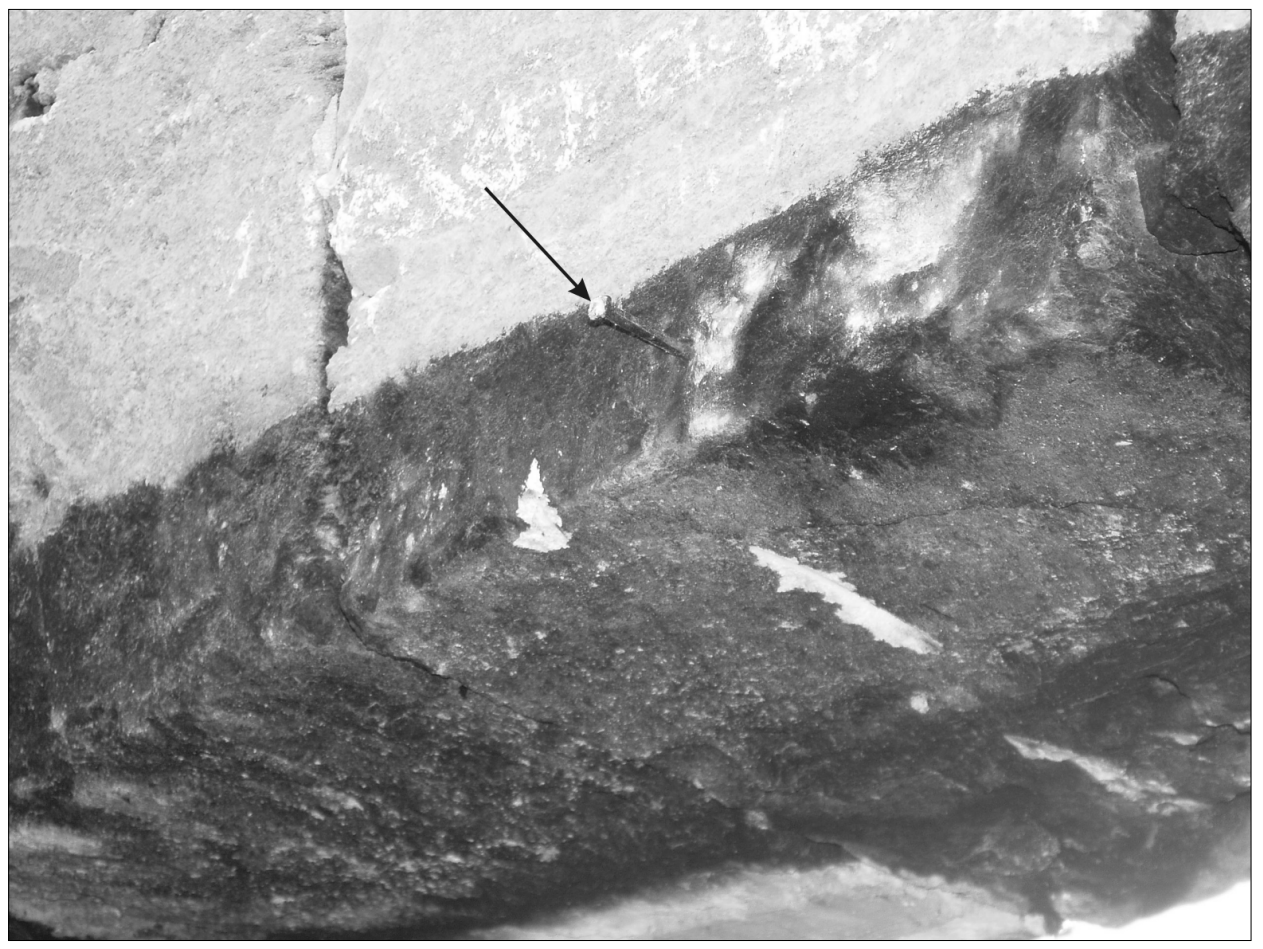

Figure 42. Forged nail that originally supported wood framing around the south window of Addition 1 .

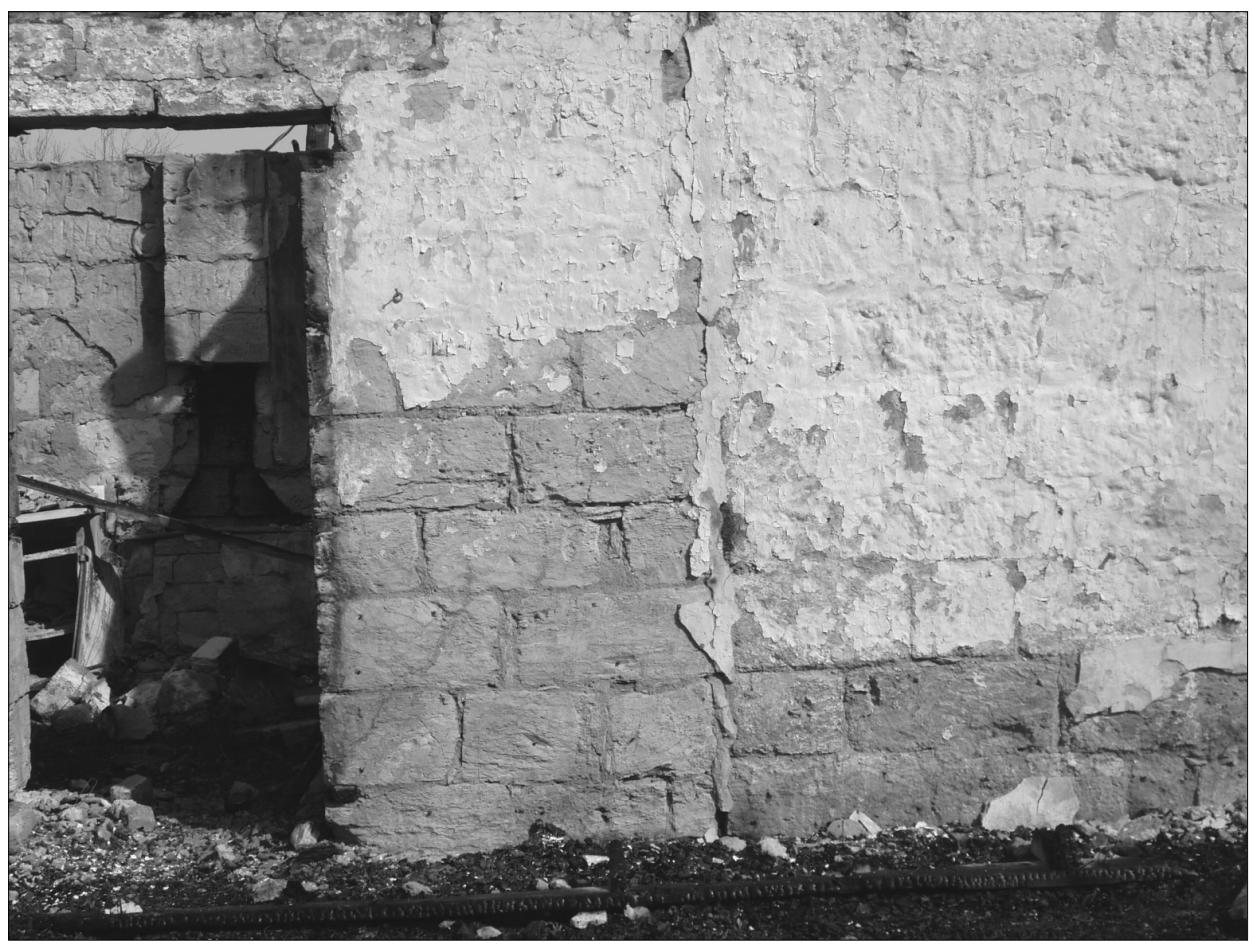

Figure 43. Abutment line and easternmost doorway of Addition 3 to Benke/Naegelin homestead. 


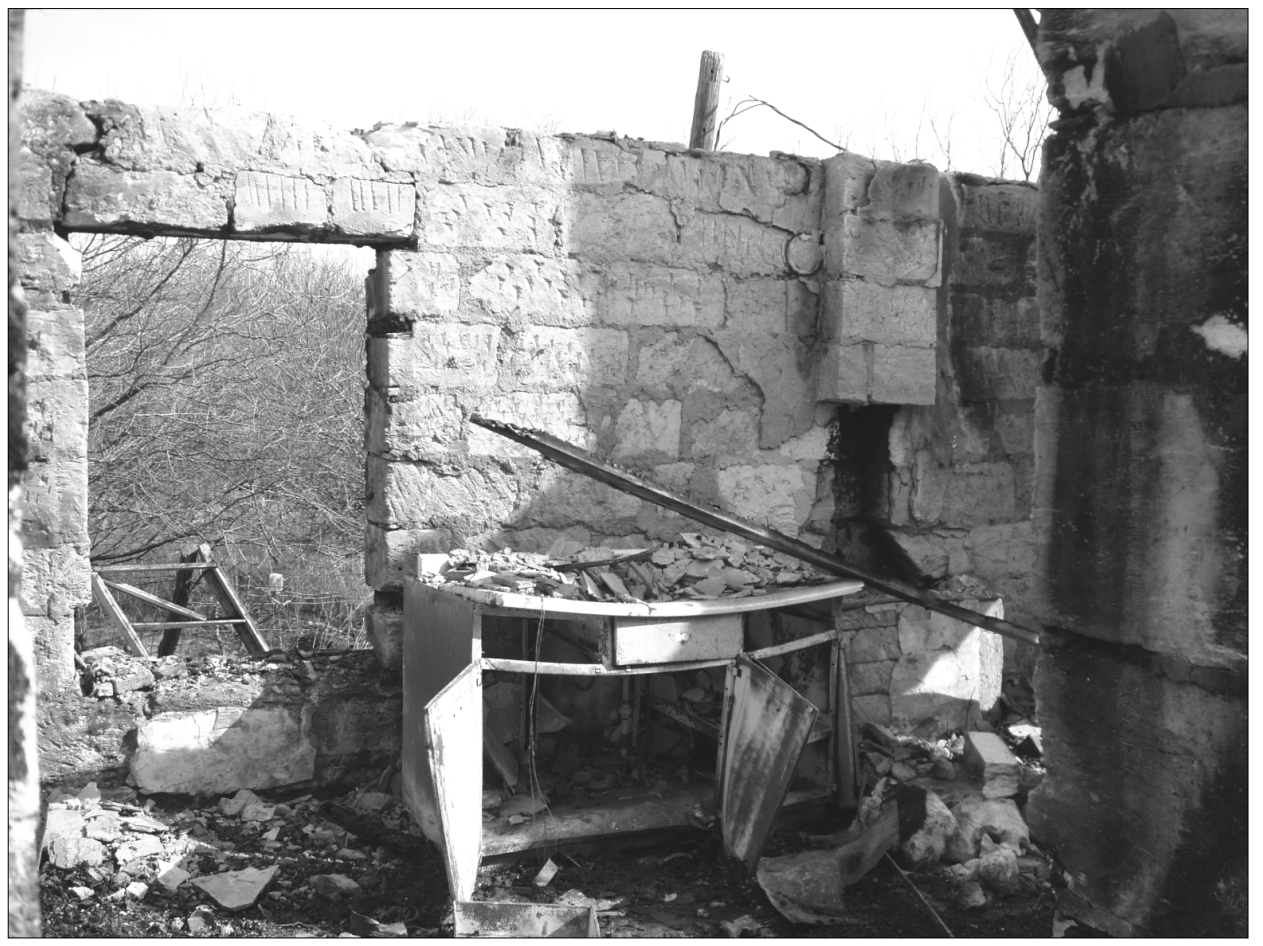

Figure 44. Hearth in north wall of Addition 3. Also note north wall window and stonework detail.

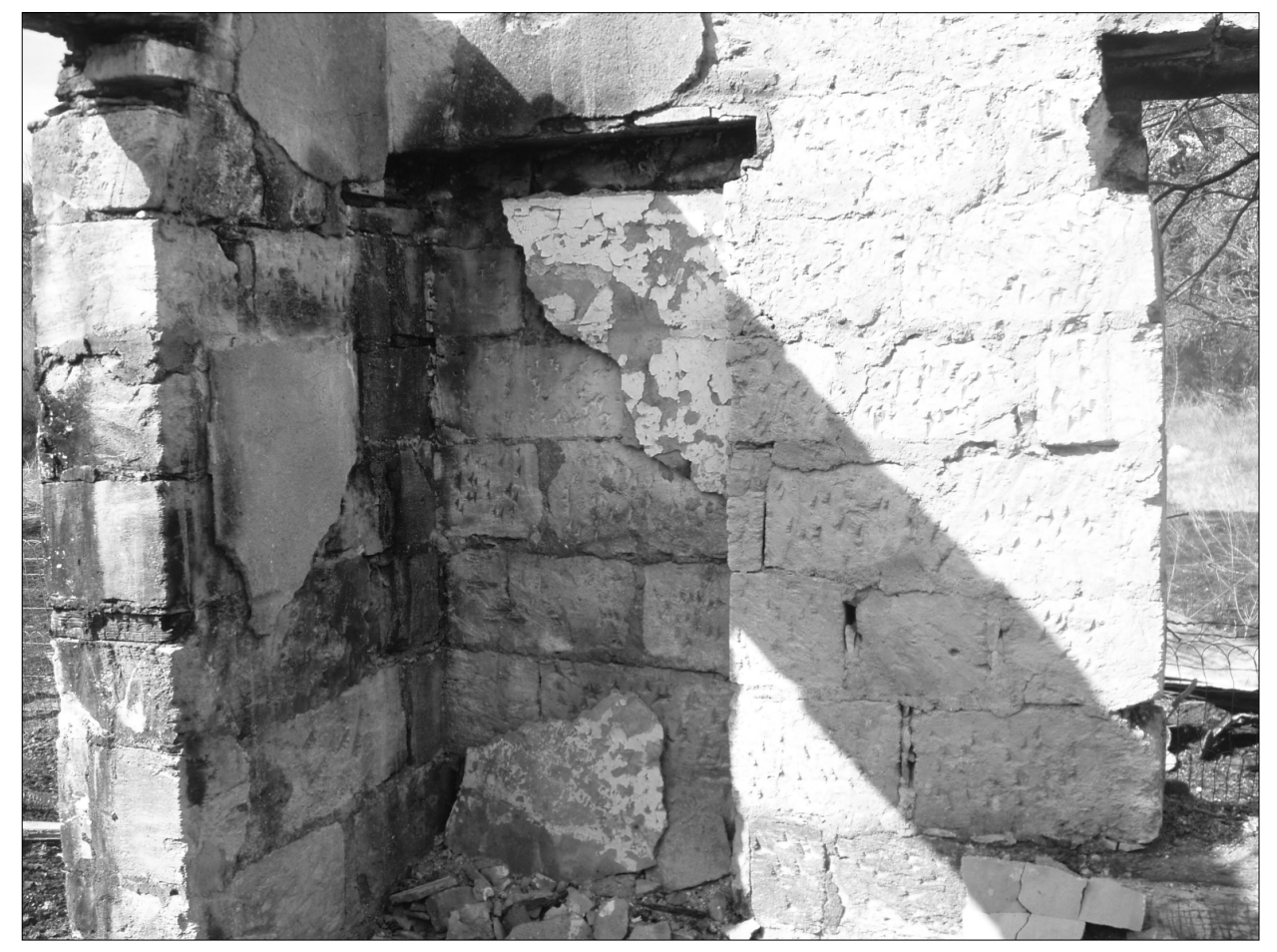

Figure 45. Niche in west wall of Addition 3, south of window. 
some later point with a chimney pipe opening (Figure 46). None of the other doorways or windows incorporated keystones in their construction and the wood framings around these openings were secured by wire nails (Figure 47). Finally, the quarry marks on the stone used in this addition are different from the marks on the stones in the original structure (Figure 48).

\section{German Architectural Influence in San Antonio and Bexar County}

Due to the German presence in Texas, particularly in Bexar and the adjacent counties of Bandera and Medina, there are good examples of German architectural style that date to the nineteenth century. German immigrants began to arrive in Texas about 1830, and by 1850 , five percent of the population in Texas consisted of German immigrants (Jordan 1977). Between 1844 and 1847, 7,000 German immigrants had reached Texas, including San Antonio (Jordan 1977:6). It was at this time that Castroville became the nucleus of the Alsatian colony, though many settlers choose San Antonio due to better opportunities. In the postbellum period (1865-1890), approximately 40,000 more German immigrants arrived. After 1890, German immigration began to taper off (Jordan 1977:8).

Early historic architecture in Bexar County consisted of Spanish-Mexican adobe structures, also known as palisado structures (Alexander 1966:11). While some German immigrants were influenced by neighboring Hispanics to employ palisado elements into their homesteads, AngloAmerican $\log$ construction was also employed, especially in the Texas Hill Country (Jordan 2005). Fachwerk, or halftimbered structures, were a second phase of German architectural style that began to appear around the mid 1800s. Buildings of limestone or sandstone began to appear about 1850 and were influenced by the architecture of the Hennsian and Frankish regions of Germany. Stone masonry is prevalent in the Hill Country and Medina County (Jordan 2005).

The Naegelin homestead is a good example of the stone construction that appeared in this region of Texas about 1850. Similar stone masonry structures include the Kammlach House in Fredericksburg and the Adrian Edward Conn House in Blanco (Alexander 1966:54, 60). These structures are not only compatible in masonry work but all

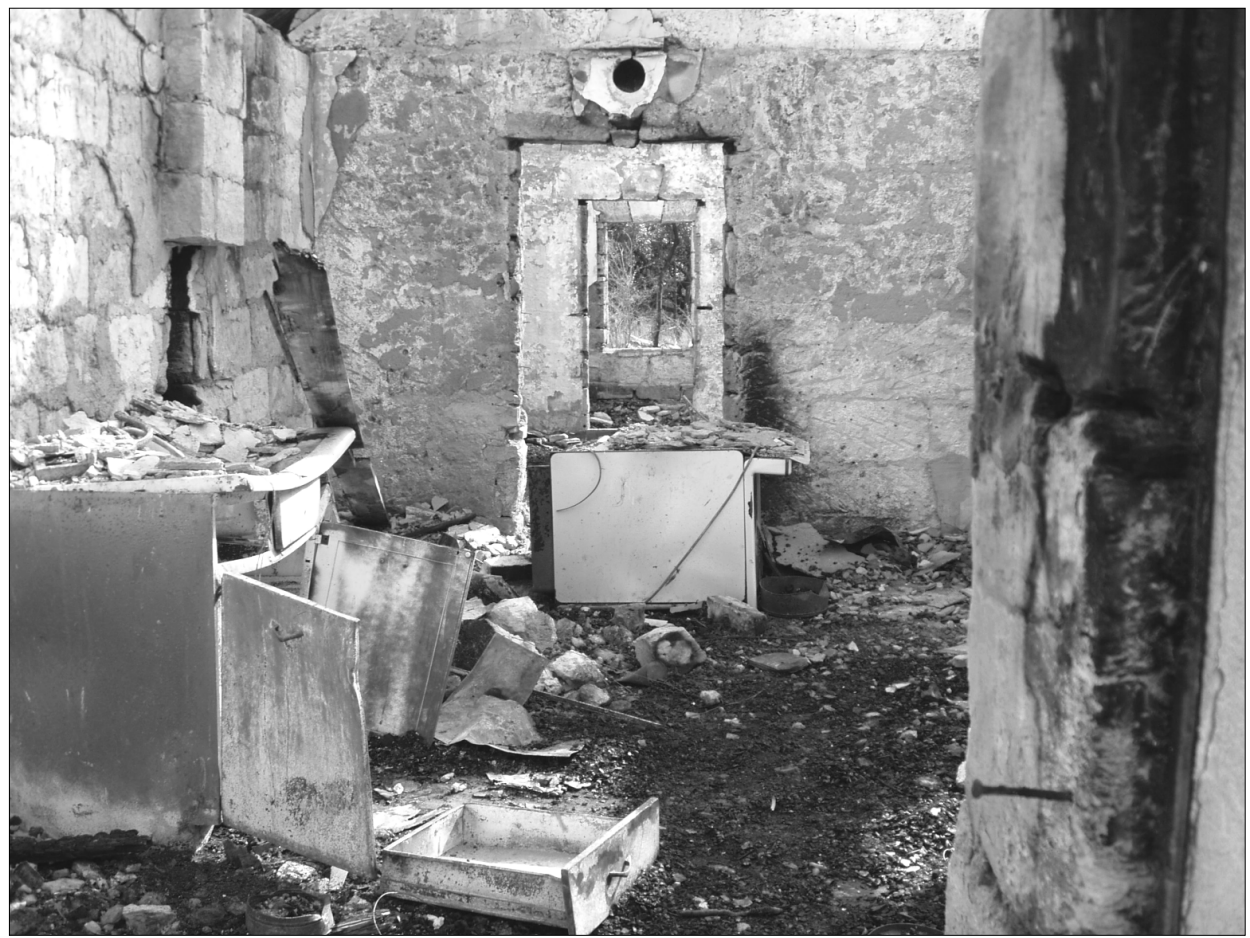

Figure 46. Chimney pipe above door to Addition 3. Note keystones above door in Addition 2 and window in original structure. 


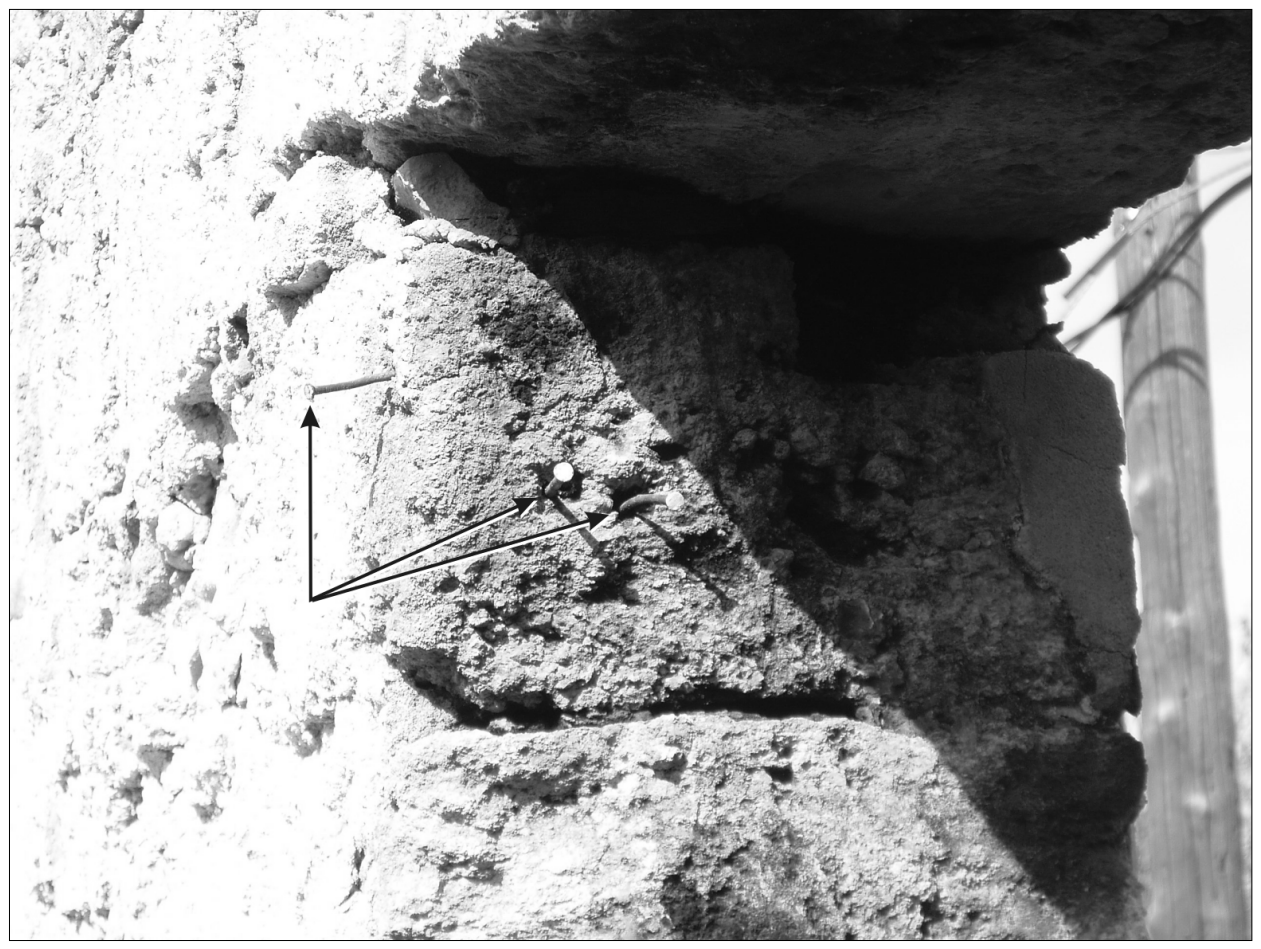

Figure 47. Wire nails that originally supported wood framing around the west doorway of Addition 2.

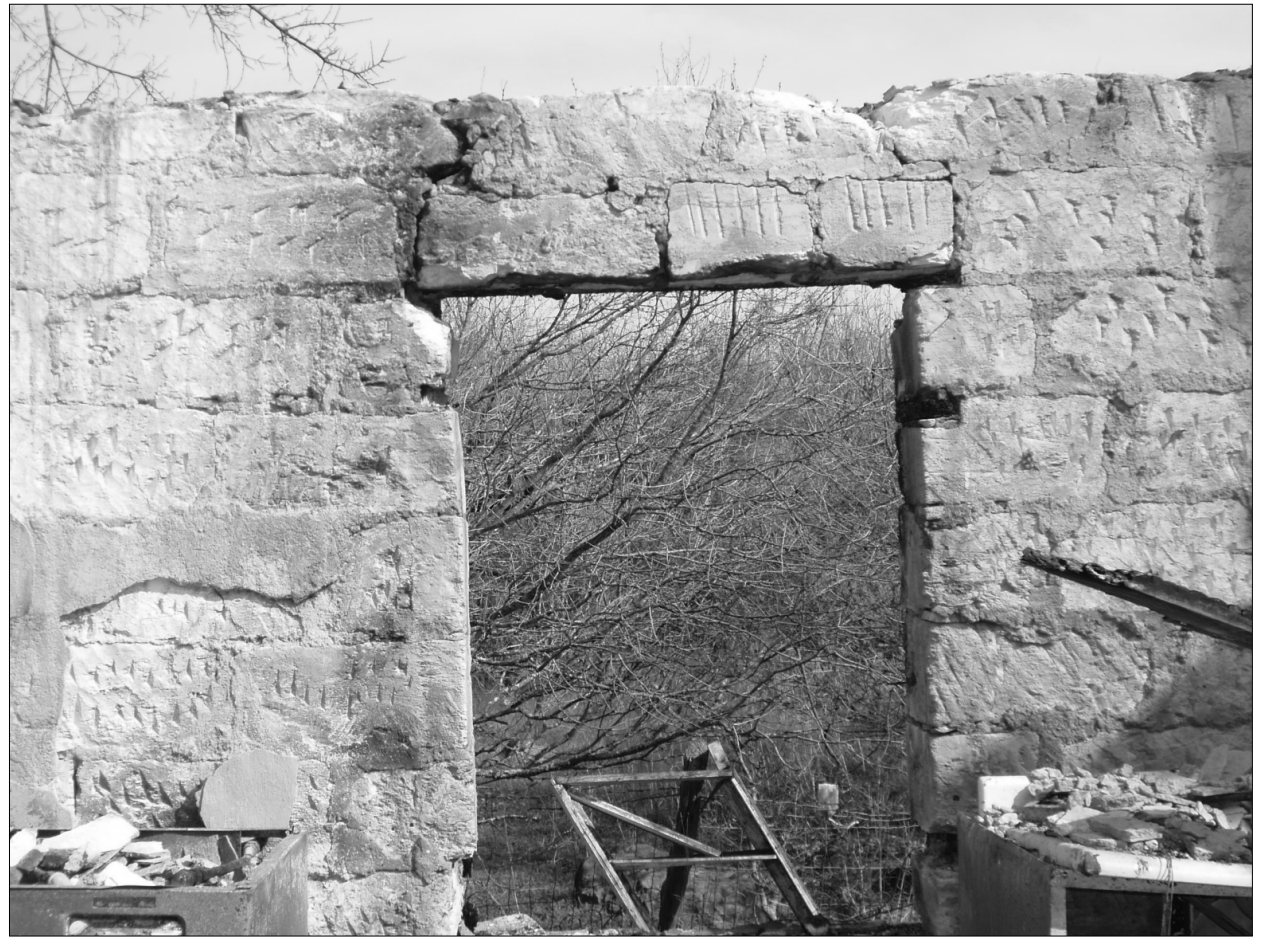

Figure 48. Addition 3 of homestead with no keystones present and chisel marks on the limestone blocks (facing north). 
three structures also exhibit a central wooden door flanked by wood-framed, double-hung sash windows and a front porch area. Additionally, the stonework of the structures in Fredericksburg and Blanco appear to have been plastered like the Naegelin homestead.

\section{Summary and Recommendations}

Staff of the Center for Archaeological Research conducted a 100 percent pedestrian survey of a 108 -acre tract in northwest San Antonio, Bexar County, Texas. Thirty-six shovel tests were excavated along 30 -meter transects and in areas considered to have high or moderate probability of buried cultural materials. No buried cultural materials were identified by any of the hand-excavated shovel tests. The survey resulted in the identification of eight isolated finds including one heavily fragmented projectile point that may represent a Bulverde dart point. No prehistoric sites were identified within the project area.

One historic site was identified during the survey, the Benke/ Naegelin Homestead (41BX1600). The site is located within the proposed right-of-way of the planned expansion of De Zavala and Kyle Seale roads (Figure 49). Subsequent to the original survey and production of the first draft report, and at the request of the Texas Historical Commission, CAR conducted archival research and interviews with two of the former owners/residents of the homestead. Through these interviews, it was established that the original structure on the property was built sometime around 1888 and that subsequent stone additions were completed by about 1903 . A 1939 historic aerial photograph shows a total of 11 structures, the windmill and the water tank on the homestead.

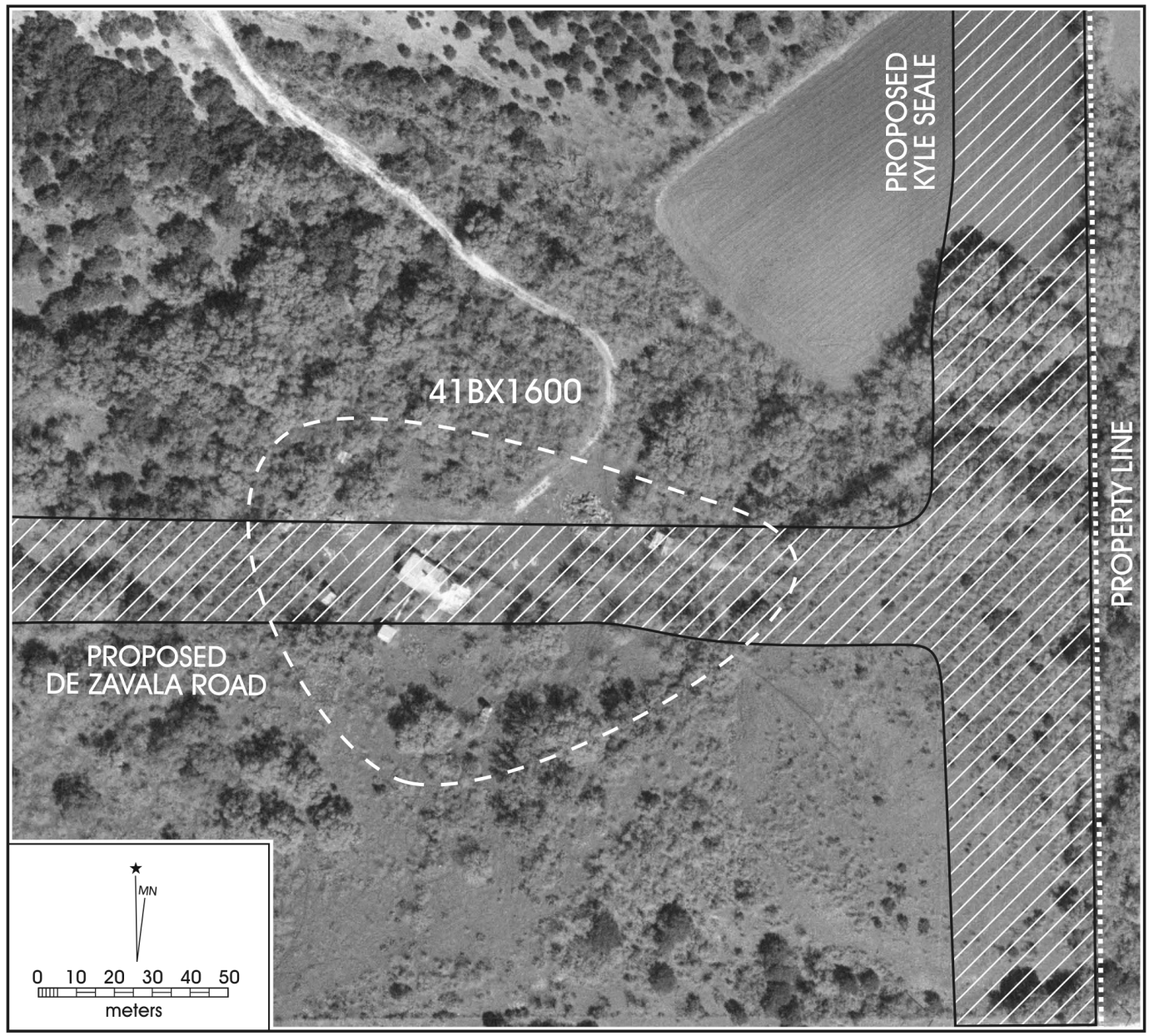

Figure 49. Location of site $41 B X 1600$ within the planned road construction right-of-way. 
Using the aerial photograph in addition to the oral histories, it has been possible to document that at least elements of Outbuildings 2, 3, 4, 5, 6, 7 and 10, and the windmill date to 1939 or before. In addition, at least four other outbuildings were present on site in 1939 but were no longer visible during the pedestrian survey. Finally, three outbuildings (1, 8 and 9 ), a cattle chute, and a concrete slab do not appear on the aerial photograph and are later additions to the complex.

Interviews with one of the former residents of the homestead also established that an unmarked burial of one of the previous occupants is still present on the property. During a visit to the homestead, Mrs. Mildred Babcock identified the approximate location of the unmarked burial as being along the southern edge of the agricultural field located northeast of the homestead.

Subsequent to the initial recording of the site and after the completion of the first draft report, the main stone complex was severely damaged by fire. While the fire revealed architectural details that were not previously noted, it also severely weakened the structure. In addition, asbestos was discovered within the ruins of the complex and its abatement could not proceed given the potential risks to the abatement crews by the weakened walls. Therefore, the walls of the structure were razed as was the only structure not previously damaged by fire, Outbuilding 6 (Figure 50).
The principal stone-built structures on the compound (i.e., the residence and Outbuilding 6) were exceptional examples of Texas vernacular architecture of the late nineteenth and early twentieth centuries. On the interior, the residence had become dilapidated through years of neglect and abandonment. Nonetheless, it retained structural integrity and exemplified changes in architectural elements over a period of roughly 10 years of additions to the original core stone structure. Following the fire, and the razing of the only undamaged building on site, the stone buildings retain no structural integrity and the site is not recommended as eligible for nomination to the National Register of Historic Places or for formal designation as a State Archeological Landmark. In addition, during a February 2005 meeting of the City of San Antonio Historic and Design Review Commission, the board failed to qualify the buildings on 41BX1600 as City of San Antonio Landmarks (Appendix C).

In summary, no additional archaeological work is recommended in association with this development. Given that the unmarked grave present on site 41BX1600 is located outside of the immediate area of impact, its relocation to Zion Lutheran Cemetery may be unnecessary, although perhaps desirable.

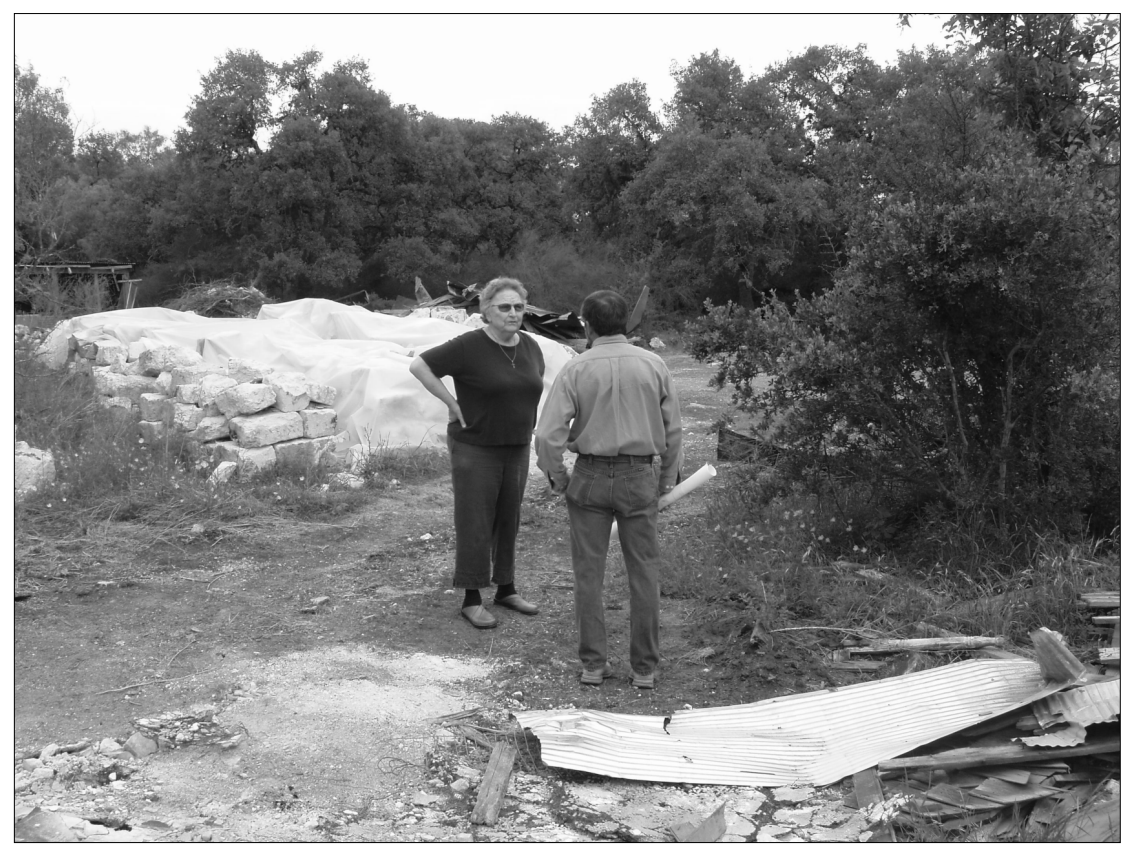

Figure 50. Photograph of the Naegelin property after the razing of the main house and root cellar (Mrs. Mildred Babcock, left, Steve Tomka, right). 


\section{References Cited}

Alexander, D. B.

1966 Texas Homes of the Nineteenth Century. The University of Texas Press, Austin.

Benke, R.

n.d. Genealogical Information on the Benke Family. On file, Center for Archaeological Research, The University of Texas at San Antonio.

Bracken, D. K., and M. W. Redway

1956 Early Texas Homes. Southern Methodist University, Dallas.

Genealogy.com

2003 GENFORUM. Alexander Benke (Benko) m. Elise (Elizabeth) Schmidt. Posted March 9, 2003. <http:// genforum.genealogy.com> Accessed March 2005.

Jordan, T. G.

1977 German Element in Texas: An Overview. Rice University Studies. Vol. 63(3).

2005 German Vernacular Architecture. Texas Handbook Online $<$ http://www.tsha.utexas.edu/handbook/online/articles/ view/GG/cbg1.html> Accessed March 2005.

Taylor, F. B., R. B. Hailey, and D. L. Richmond

1962 Soil Survey of Bexar County. Soil Conservation Service, Washington, D.C.

Texas Historical Commission (THC)

2004 Texas Archeological Sites Atlas. <http://www.pedernales.thc.state.tx.us/> Accessed November.

Zion Lutheran Church of Helotes Archives

2005 Zion Lutheran Obituaries $<$ http://lonestar.texas.net/ gdalum/obits.html $>$ Accessed March.

2005 Zion Lutheran Cemetery Inscriptions. $<$ http://lonestar.texas.net/ gdalum/obits/> Accessed March. 



\section{Appendix A}

Genealogy of the Benke (Benko) Family 
Descendants of Alexander Benko (Benke)

$\begin{array}{lc}\text { Alex J. Benke } & 1859 / 1941 \\ \text { Elisa Biering } & 1861 / 1943 \\ & \\ \text { Arnold Gugger } & 1855 / 1928 \\ \text { Amalia Benke } & 1861 / 1921 \\ & \\ \text { Albert Benke } & 1862 / 1904 \\ \text { Catherine Hoffman } & 1864 / 1936 \\ & \\ \text { Anna R. Benke } & 1867 / 1885 \\ & \\ \text { Fred Benke } & 1868 / 1944 \\ \text { Sarah Lee } & 1874 / 1939 \\ & \\ \text { John Mehlich } & ? ? ? ? / ? ? ? ? \\ \text { Bertha Benke } & 1869 / 1924 \\ & \\ \text { Fred Russell } & 1863 / 1899 \\ \text { Hulda Benke } & 1869 / 1924 \\ & \\ \text { Adolph John Benke } & 1872 / 1962 \\ \text { Lydia Tillie Schaefer } & 1891 / 19 ? ? \\ & \\ \text { William Herman Benke } & 1876 / 1938 \\ \text { Ida Sewald } & 1876 / 1947 \\ & \\ \text { Gus Sagray } & 1881 / 1952 \\ \text { Agusta Marie Benke } & 1877 / 1977 \\ & \\ \text { Gus Sagray } & 1881 / 1952 \\ \text { Agusta Marie Benke } & 1877 / 1944 \\ & \\ \text { Albert Moos } & 1859 / 1943 \\ \text { Ellen Helen Benke } & 1880 / 1927 \\ & \\ \text { Otto M.A. Benke } & 1881 / 1949 \\ \text { Margaret Lee Heise } & 1888 / ? ? ? ?\end{array}$

Alexander Benko (Benke) 1824/1906 Anna Elise Schmidt 
Descendants of Alex J. Benke and Elise Biering

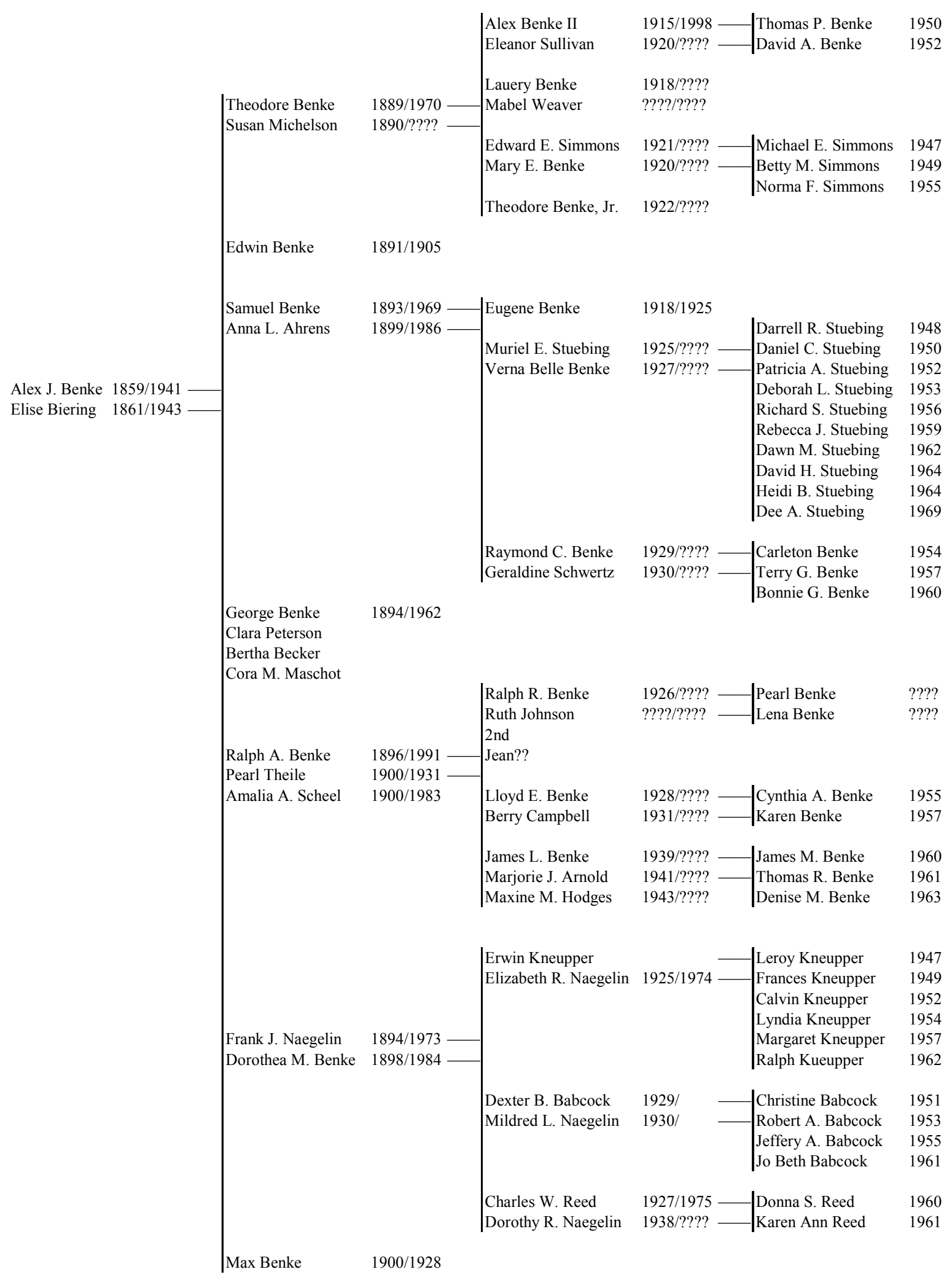



Appendix B

Structural Integrity Inspection of 12930 South Hausman Road [Site 41BX1600]

STC Environmental Services, Inc. 


\section{STC}

Environmental Services Inc.

Environmental Scientists and Engineers

4754 RESEARCH DRIVE

March 14, 2005

Mr. Terry Casey

Northside Independent School District

5900 Evers Road

San Antonio, Texas 78238

RE: Structural Integrity Inspection of 12930 South Hausman Road, San Antonio, TX 78249

STC Project 24442

Mr. Casey:

On Friday, March 11, 2005, Mr. David O. Scheiding P.E. visited the subject site with the expressed purpose to design structural shoring in order to accomplish asbestos abatement activities. The following comments document the results of that inspection and project background information.

\section{BACKGROUND INFORMATION}

A Phase I Environmental Site Assessment was completed in August 2002. Asbestos containing materials were identified to be present. On August 3, 2004, STC was asked to confirm the presence and types of asbestos containing materials. Asbestos containing sheet vinyl and floor tile were confirmed to be present essentially throughout the structure. During this asbestos inspection, the question of historical significance was raised. After considerable discussion and research, the structure has been declared to be of historical significance. However in January 2005, during the time period of discussion and research, vandals set fire to the structure. After the fire only the limestone walls remained standing (See Photos 1, 2, 3, 4, 5, 6 and 7). The smaller limestone structure was not vandalized (See Photo 8).

As a result of the fire, the asbestos containing materials was reduced to charred debris (See Photos 9, 10 and 11). Due to the historical significance, it was determined that it would be possible to shore the structure in order to complete the asbestos abatement if completed on a timely basis. If subjected to rain events, this option would not be possible due to the rain effects on the mortar of the limestone which would significantly reduce the structural integrity. On February 23, 2005 the structure was still in a condition to shore (See Photo 12).

\section{STRUCTURAL INTEGRITY INSPECTION (MARCH 11, 2005)}

During the time period of February 28 to March 6, 2005 frequent rain events occurred. On March 9, 2005 the site was visited to log the water well that is also on site and the structure 
STC

Environmental Services, Inc.

was still intact. However on March 11, 2005 when STC visited the site to design the required shoring, the south wall on the west end of the structure was laying on the ground (See Photo 13). It is suspected that vandals caused the destruction since a portion of the wall was lying inside the structure (See Photo 14) while another portion was lying outside the structure (See Photo 15 and 16). Weather had not been a factor since March 7,0205 and the structure was still intact on March 9, 2005.

\section{CONCLUSIONS}

As a result of this wall destruction it is no longer considered feasible to shore the structure in order to complete the asbestos abatement. In fact the structure is now considered structurally unsafe and is considered to represent a significant safety risk. This has resulted since now the west wall is free standing with no support (See Photo 13). A strong wind with a cold front passing could bring this wall down. In addition, the center wall with the chimney also has lost the support of the south wall. This center wall has now become unstable (See Photos 17 and 18). A strong wind could topple the top of this wall. As a result, it is now considered unsafe to allow asbestos abatement activities to be conducted.

\section{RECOMMENDATIONS}

It is strongly recommended that the remaining structure be demolished as soon as possible from the exterior under NESHAPs regulations governing structures containing asbestos. The debris will require disposal as asbestos containing material. This is recommended since this structure is now considered to represent a significant safety risk to the public since the area is not secure. It is suspected that vandals set the fire since the structure was also tagged with paint from the near by residential development. It is also suspected that vandals returned to cause the most recent destruction of the south wall. If vandals return again, they in fact would significantly endanger themselves if they attempt further destruction. In addition, if any homeless individuals seek shelter during inclement weather or strong winds, they would be at great risk due to not only the collapse of walls, but also exposure to asbestos. Therefore any delay in demolition is considered to greatly increase the safety risk present to the public and represents significant liability to the owner.

If you have any questions concerning the above, please do not hesitate to contact our office at (210) 696-6286.

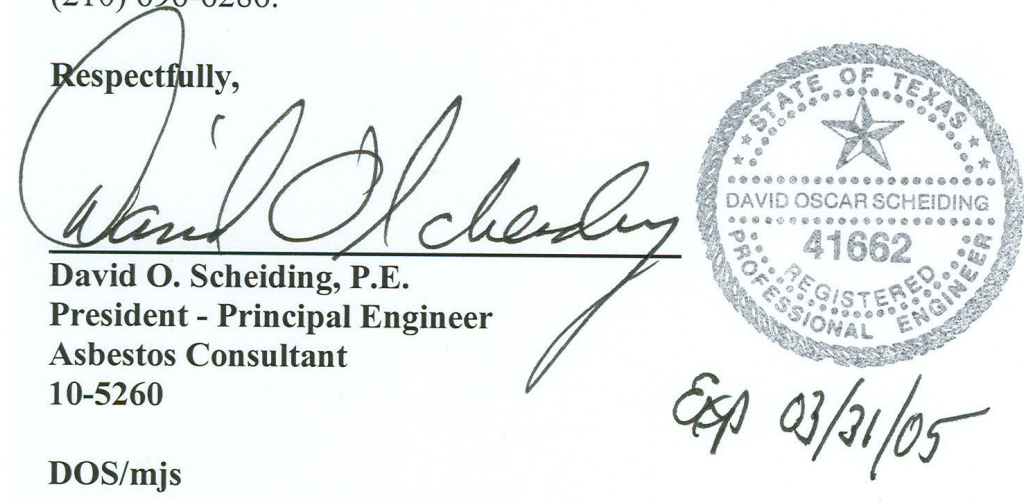


STC Project 24442 - 12930 S. Hausman Road

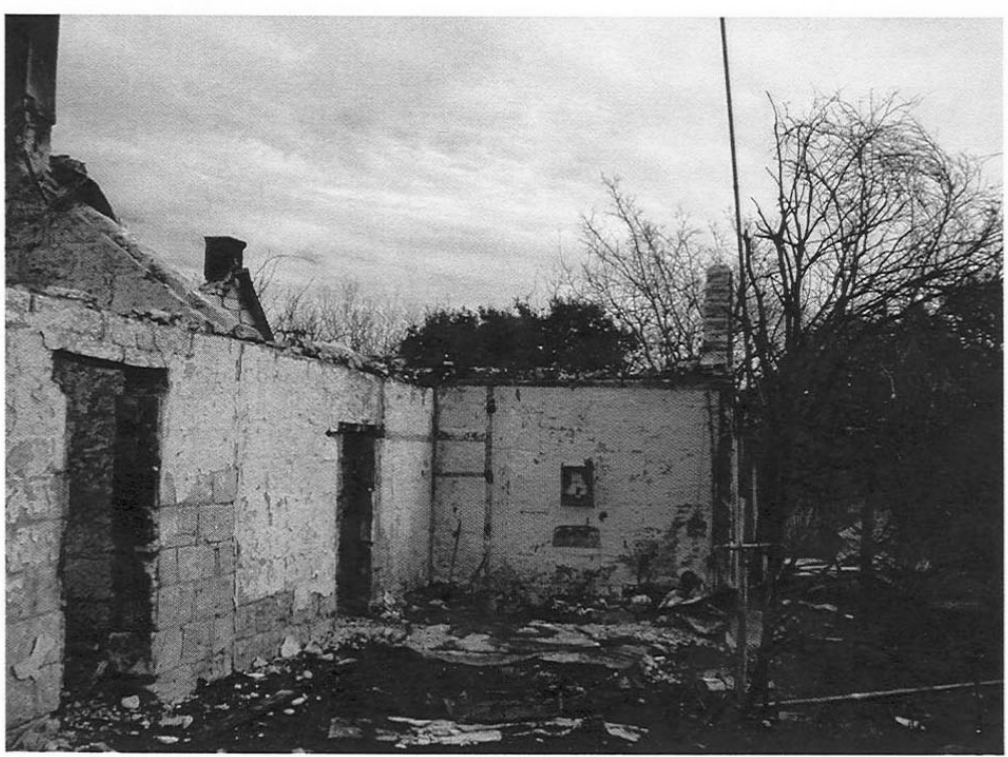

PHOTO 1: View of structure after the fire in January 2005.

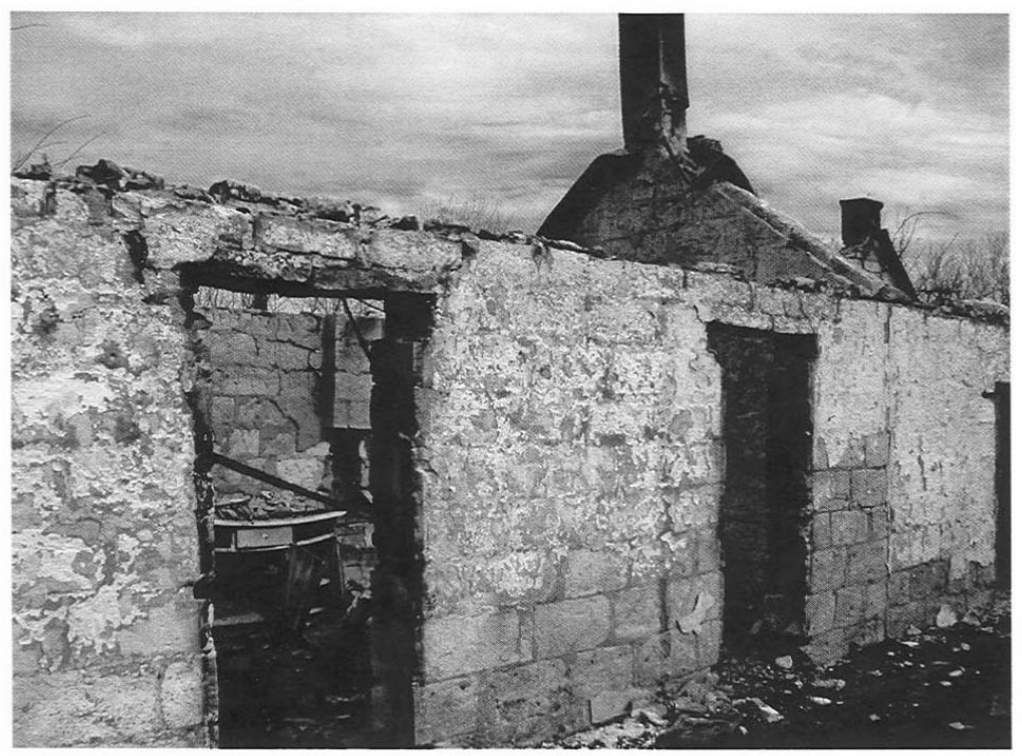

PHOTO 2: Additional view of structure after the fire.

STC

Environmental Services, Inc. 4754 RESEARCH DRIVE 
STC Project 24442 - 12930 S. Hausman Road

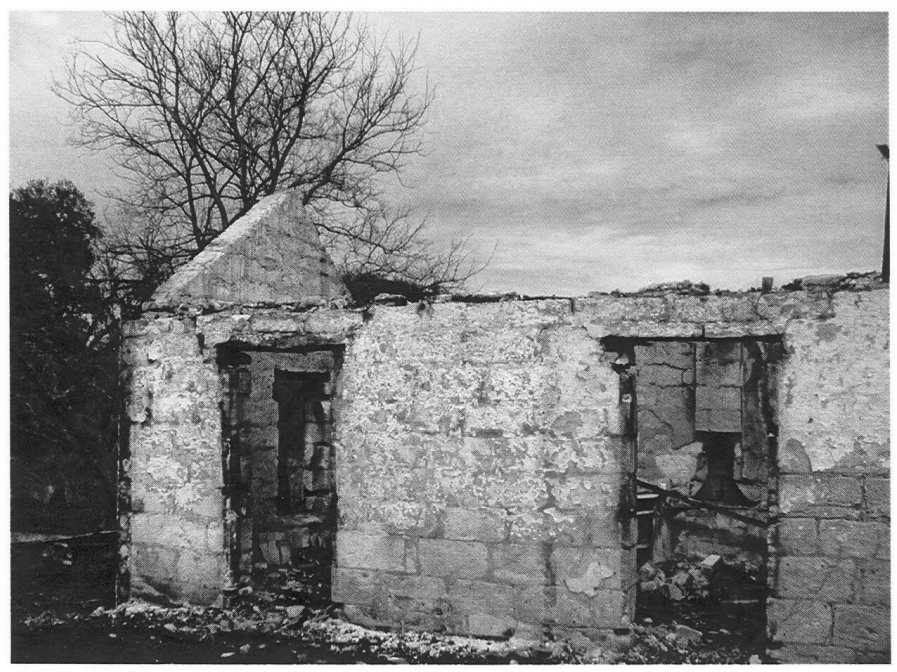

PHOTO 3: Additional view of structure after the fire.

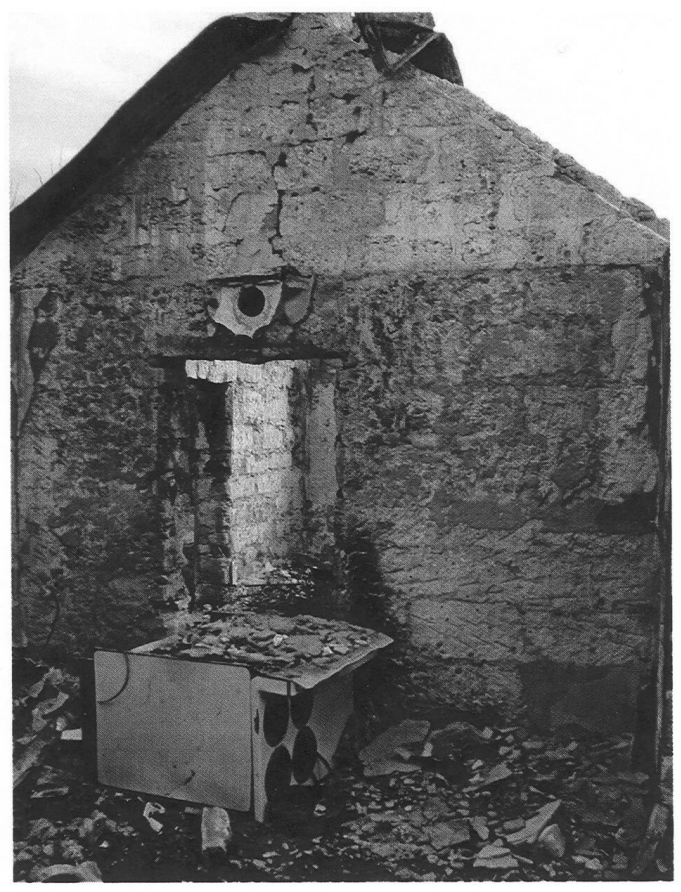

PHOTO 4: Additional view of structure after the fire.

STC

Environmental Services, Inc. 4754 RESEARCH DRIVE 
STC Project 24442 - 12930 S. Hausman Road

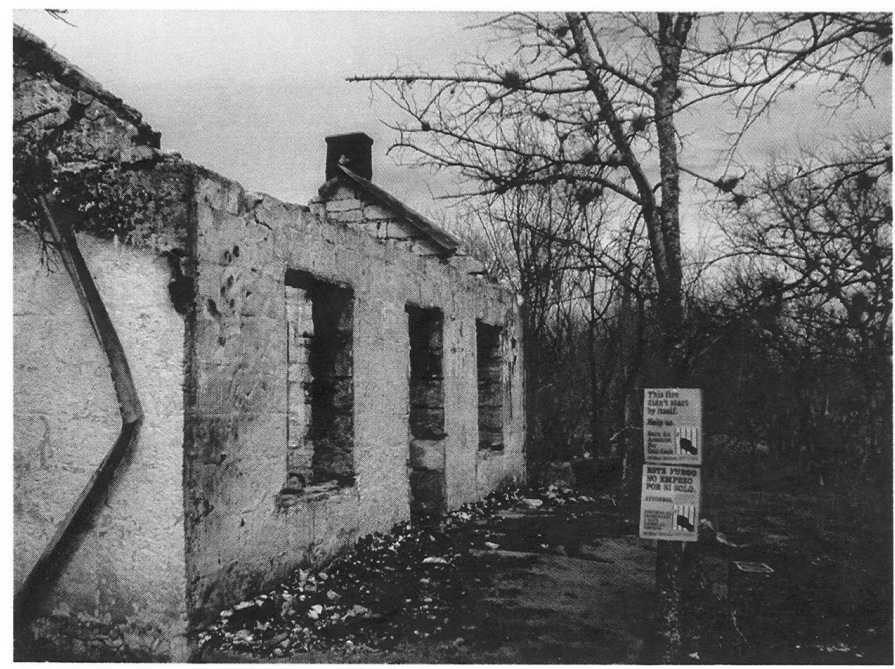

PHOTO 5: Additional view of structure after the fire.

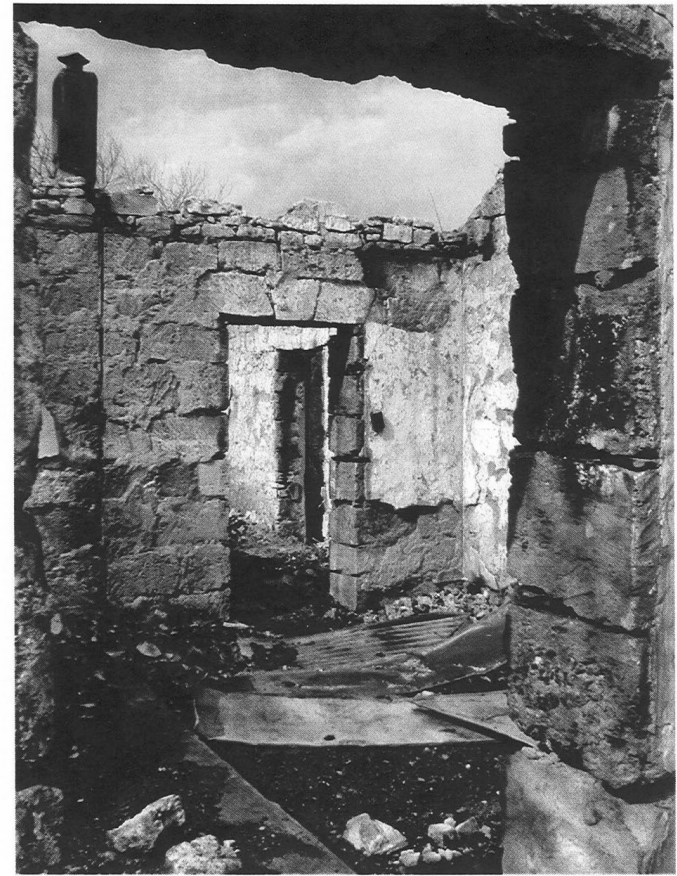

PHOTO 6: Additional view of structure after the fire.

\section{STC}

Environmental Services, Inc. 4754 RESEARCH DRIVE 
STC Project 24442 - 12930 S. Hausman Road

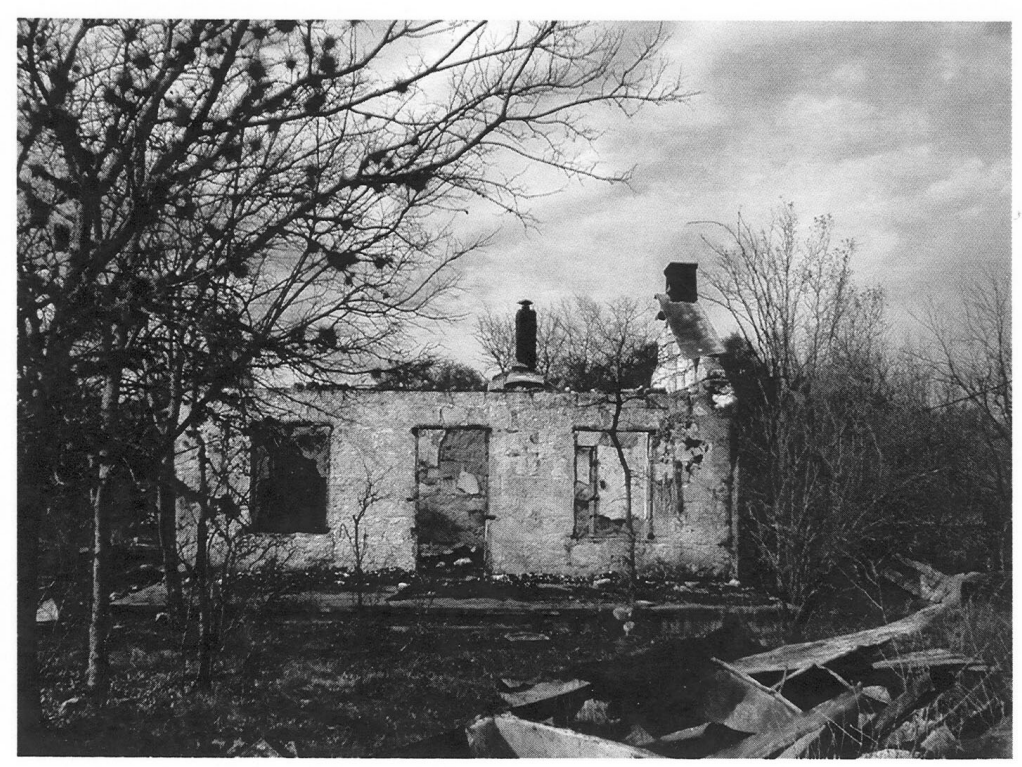

PHOTO 7: Additional view of structure after the fire.

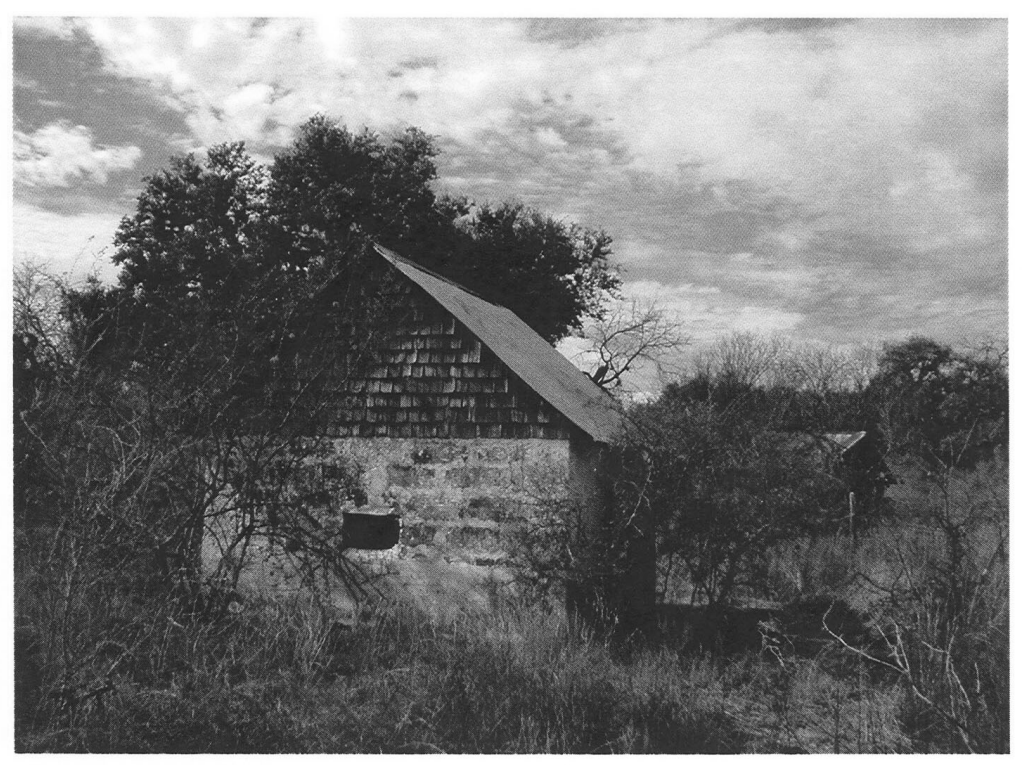

PHOTO 8: View of small structure currently still standing on the site.

\section{STC}

Environmental Services, Inc. 4754 RESEARCH DRIVE 


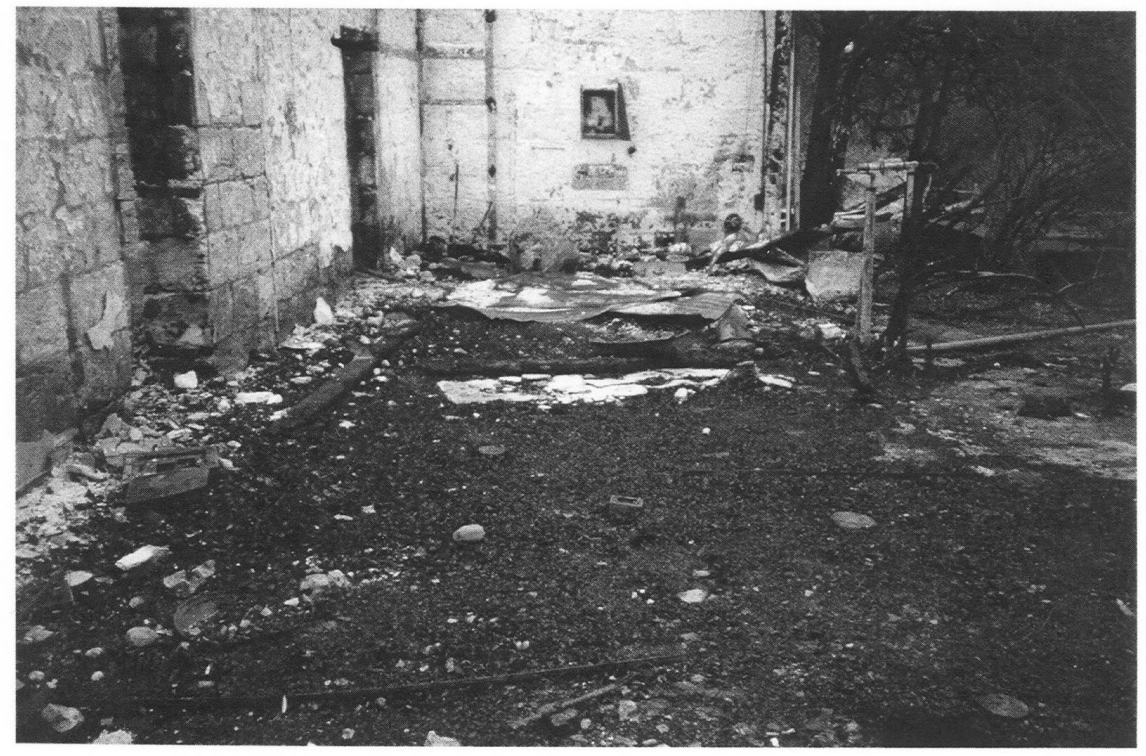

PHOTO 9: View of asbestos containing debris present within the footprint of the structure after the fire.

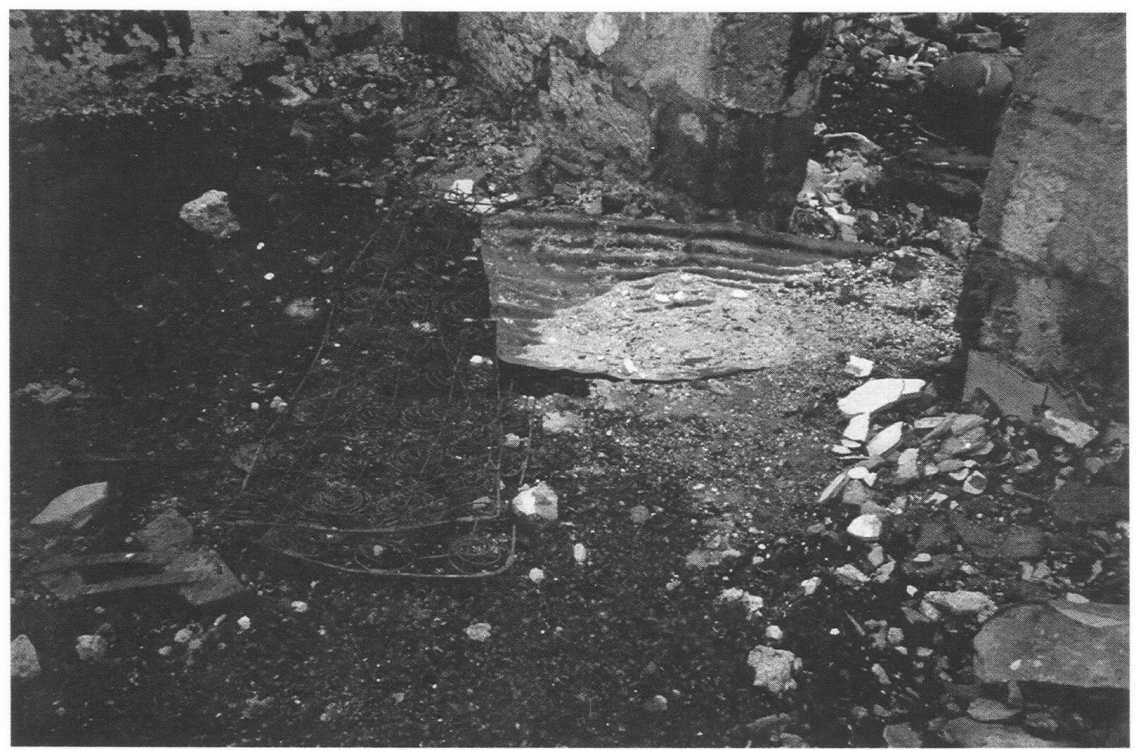

PHOTO 10: Additional view of asbestos containing debris present within the footprint of the structure.

\section{STC}

Environmental Services, Inc. 4754 RESEARCH DRIVE 


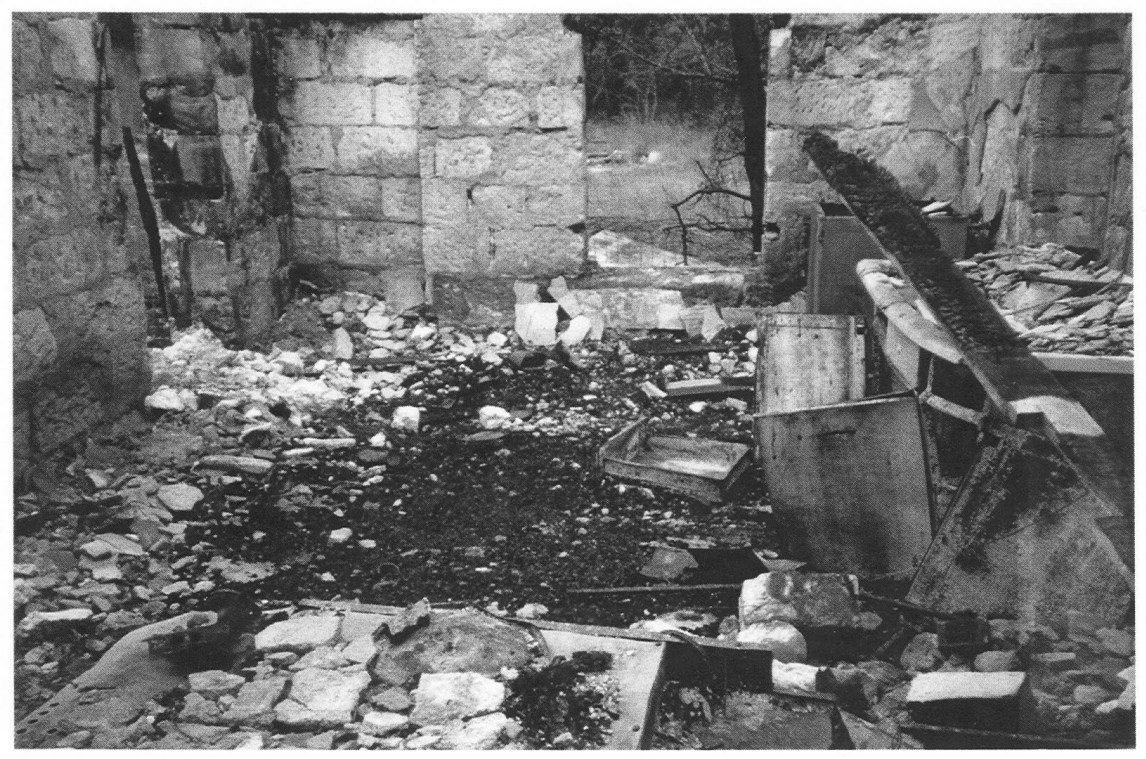

PHOTO 11: Additional view of asbestos containing debris present.

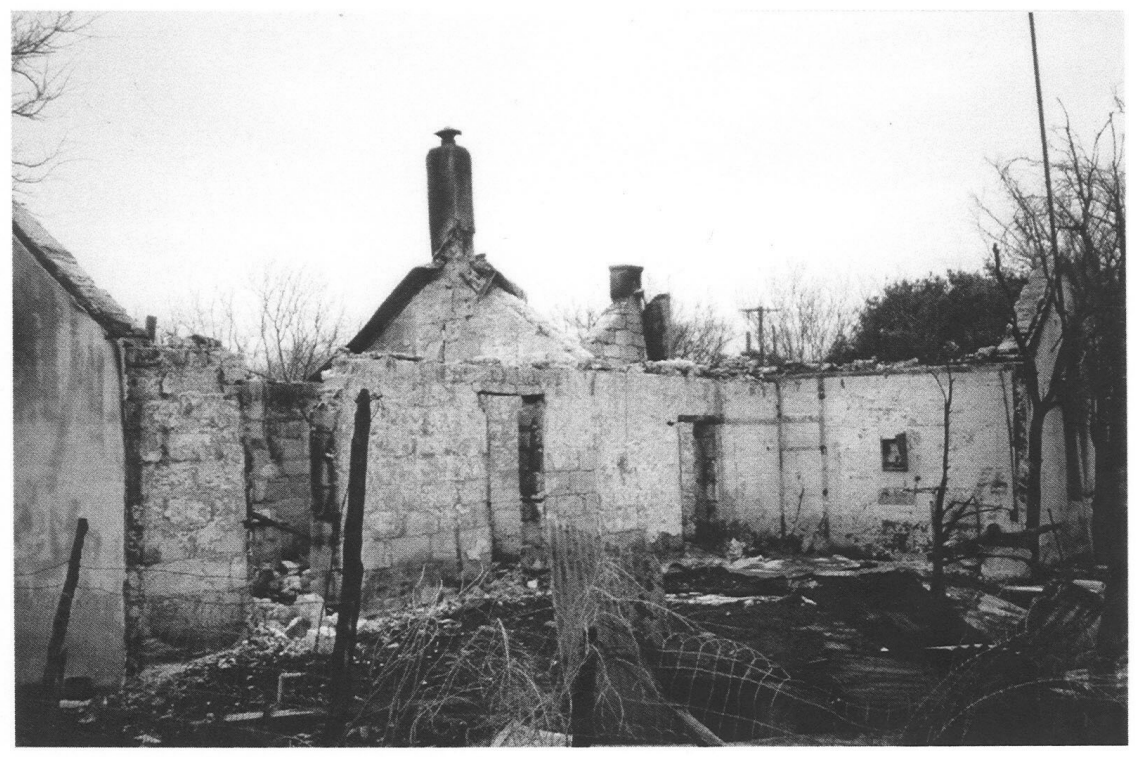

PHOTO 12: View of structure condition up to March 9, 2005.

STC

Environmental Services, Inc. 4754 RESEARCH DRIVE 


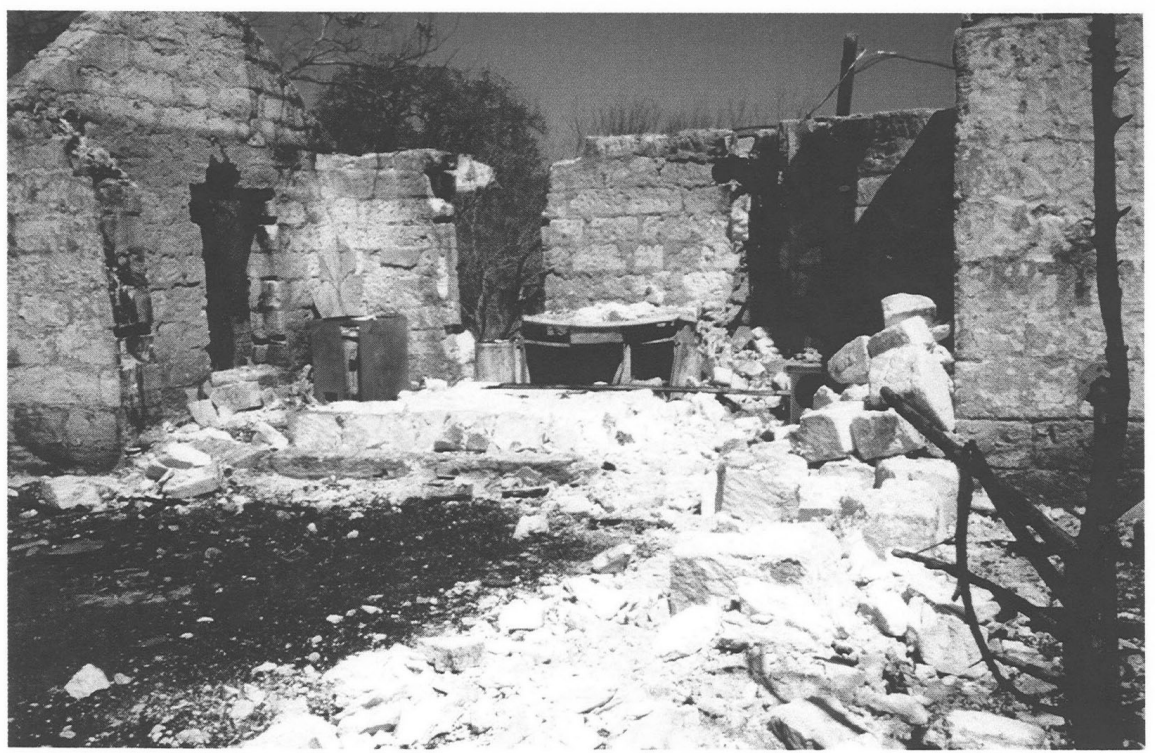

PHOTO 13: View of same wall in Photo 12 on March 11, 2005. Also shows west wall remaining as a free standing wall.

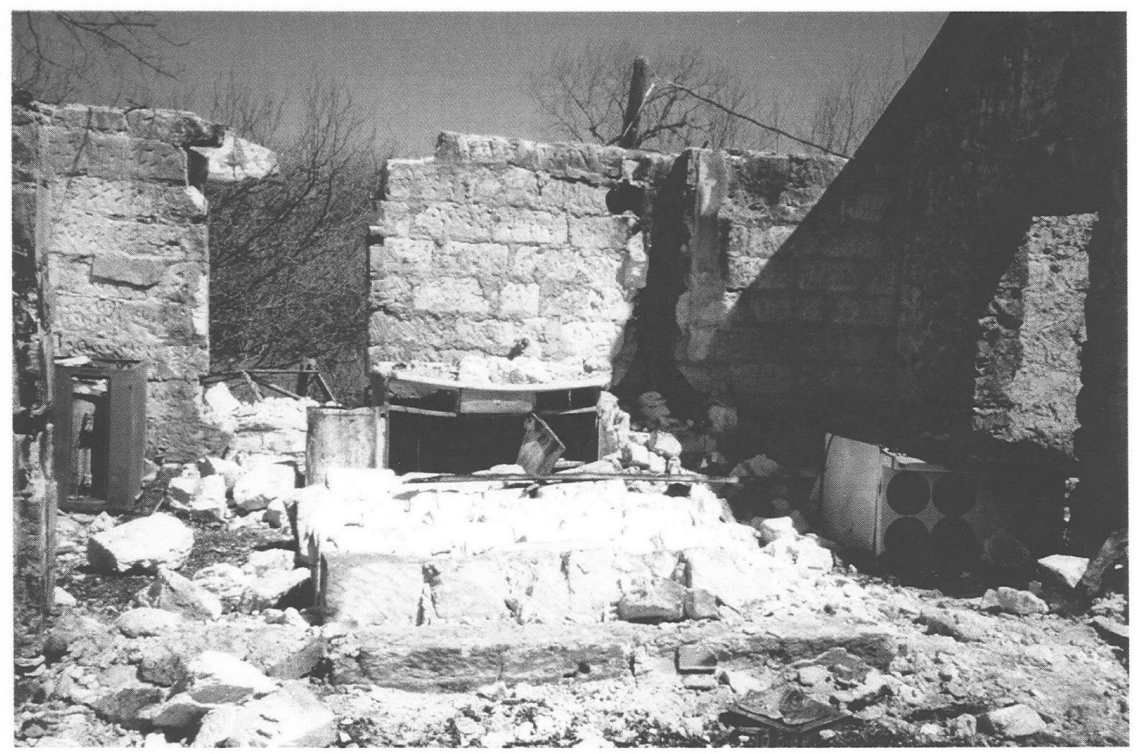

PHOTO 14: View of south wall section that collapsed inward.

\section{STC}

Environmental Services, Inc. 


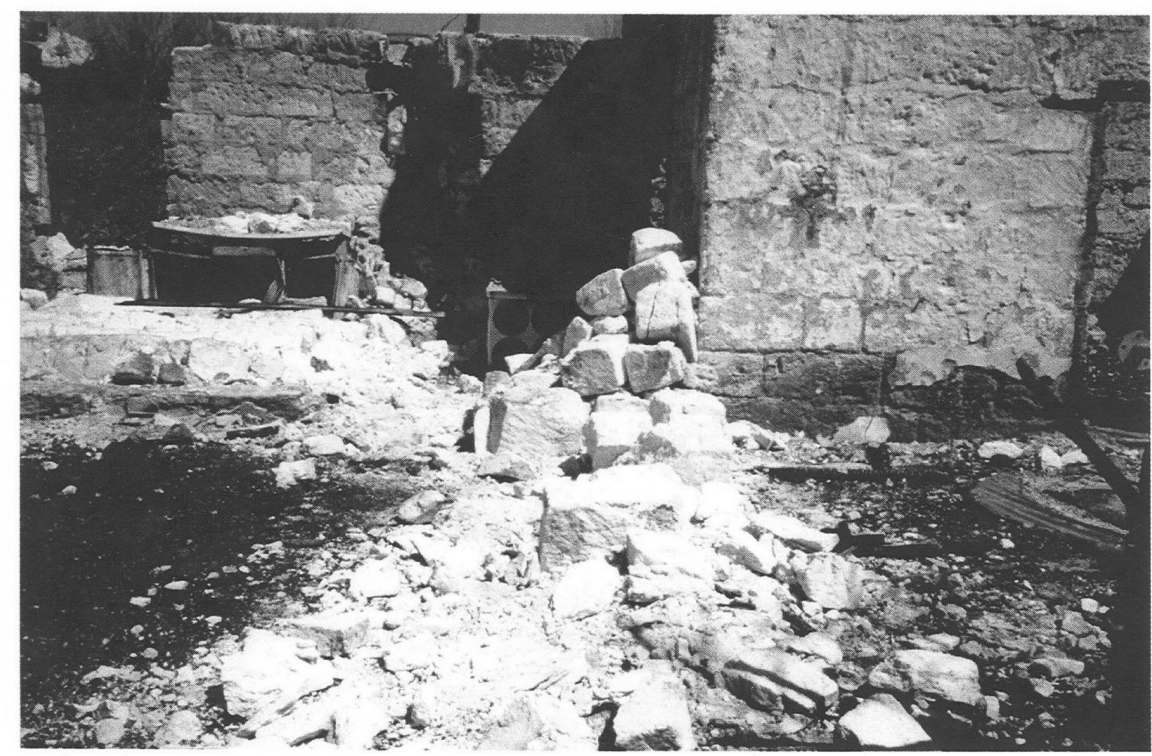

PHOTO 15: View depicting the extent of south wall outwards.

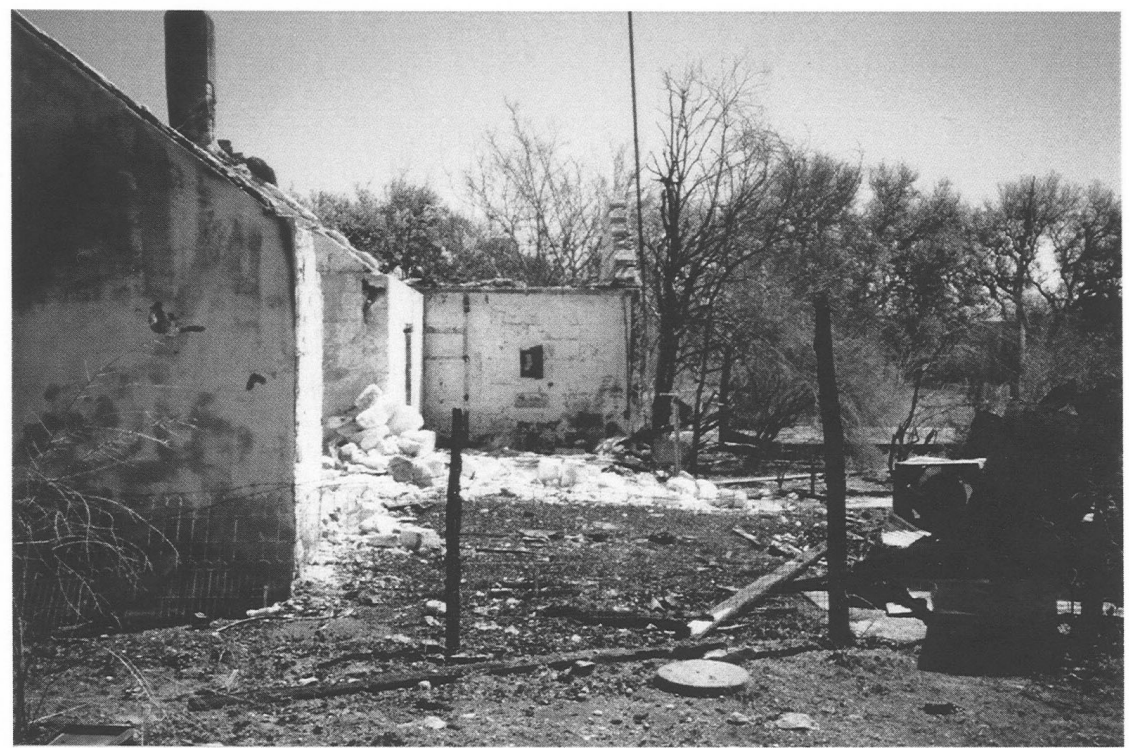

PHOTO 16: View depicting the extent of south wall outwards. 
STC Project 24442 - 12930 S. Hausman Road

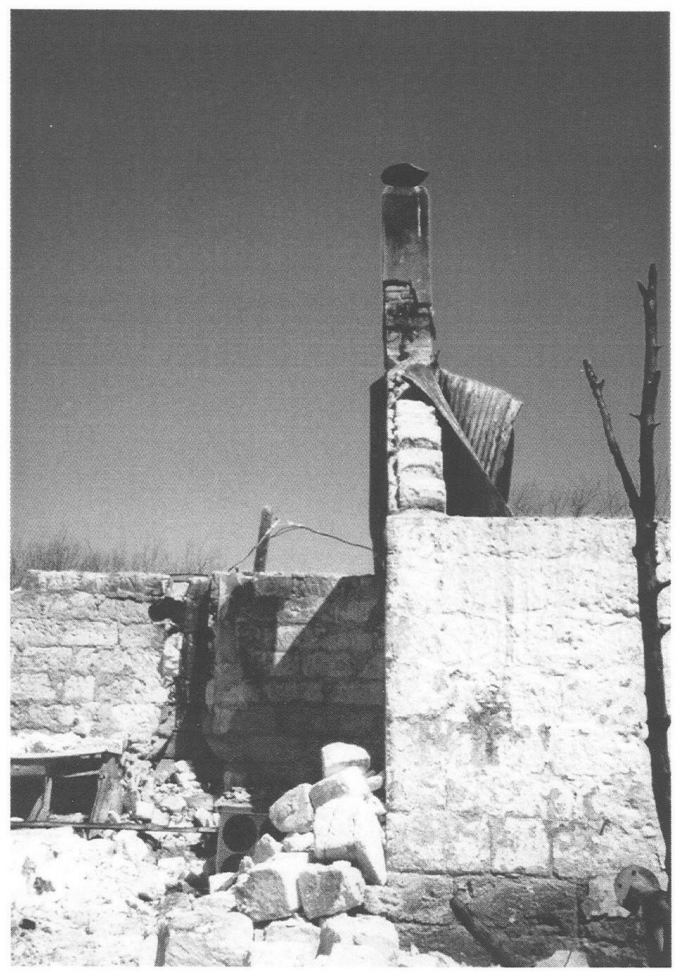

PHOTO 17: View of center wall with chimney now without the support of the south wall.

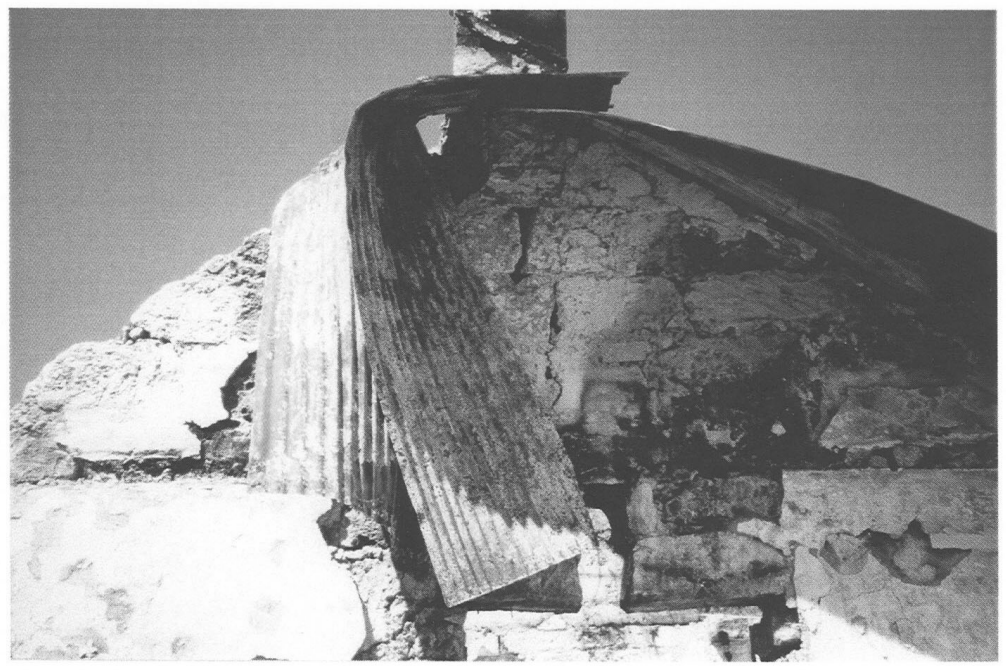

PHOTO 18: View of chimney base that has been weakened.

\section{STC}

Environmental Services, Inc 4754 RESEARCH DRIVE 
Appendix C

City of San Antonio Historic and Design Review Commission Certificate of Appropriateness 
HISTORIC AND DESIGN REVIIW COMMASSION CERTIFICATE OF APPROPRLATENESS

February 16, 8005

\section{CITY OF SAN ANTONIO}

HDRC CASE NO:

ADDRESS:

LEGAL DESCRIPTION:

PUELIE PROPERTY:

HISTORIC DISTRICT:

LAMDMARK DISTRICT:

APPLICANT:

OWNER:

TYPE OF WORK:

\section{$2004-320$}

12930 Hausman Road

NCB 14615, Block P1-C, P-A, and P.100

Proposed

\section{Clly of San Antonio, Historic P.O. Box 839806} Preservation Officer

Northside independent Schoot District.

Finding of Historic Significance

REQUEST:

The applicant is requesting a Centificate of Appropriateness for approval of a finding of historic slgnificance for the main house and smokehouse on the property. The accompanying exhlbits provide additional Information.

\section{RECOMMENDATION:}

The staff recommends approval of this request as submitted. The bulldings quallfy as a City of San Antonio Landmark according to the following criteria of the Historic and Design Section of the Unified Development Code:

(1) it is a visible reminder of the cultural heritage of the community (35-607(b)(1));

(2) its embodiment of dlstingulshing characteristics of an architectural style valuable for the study of a period, type, method of construction, or use of indigenous materials $(35-607(\mathrm{~b})(5))$;

(3) Its historical, archillectural or cultural character as a partlcularly fine example of a utilitarian structure (35-607(b)(6)):

(4) Its historical, anchiltectural, or cultural integrity of location, design, materials, and workmanship (35607 (b)(8)); and

(5) the buliding has come to represent a part of San Antonio's cultural herltage for at least twenty-ifve years $(35-607)(C)(2)(A)$.

\section{COMMISSION ACTION:}

Falled for the lack of afilmattve vates

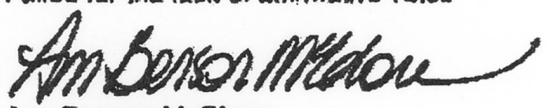

Ann Benson MisGlone

Historic Preservatton Oficer

$$
\text { PLANNDNG DEPARTMENT - RO. BOX 839966- SAN ANTONIO, TEXAS 78289-3966 }
$$

